Portland State University

PDXScholar

Spring 5-16-2014

\title{
"Dangerous Subjects": James D. Saules and the Enforcement of the Color Line in Oregon
}

Kenneth Robert Coleman

Portland State University

Follow this and additional works at: https://pdxscholar.library.pdx.edu/open_access_etds

Part of the Law and Race Commons, Political History Commons, and the Race, Ethnicity and Post-

Colonial Studies Commons

Let us know how access to this document benefits you.

\section{Recommended Citation}

Coleman, Kenneth Robert, "'Dangerous Subjects": James D. Saules and the Enforcement of the Color Line in Oregon" (2014). Dissertations and Theses. Paper 1845.

https://doi.org/10.15760/etd.1844

This Thesis is brought to you for free and open access. It has been accepted for inclusion in Dissertations and Theses by an authorized administrator of PDXScholar. Please contact us if we can make this document more accessible: pdxscholar@pdx.edu. 
"Dangerous Subjects":

James D. Saules and the Enforcement of the Color Line in Oregon

by

Kenneth Robert Coleman

A thesis submitted in partial fulfillment of the requirements for the degree of

Master of Arts

in

History

Thesis Committee:

Katrine Barber, Chair

Patricia Schechter

David Johnson

Darrell Millner

Portland State Univesity

2014 
(C) 2014 Kenneth Robert Coleman 


\begin{abstract}
In June of 1844, James D. Saules, a black sailor turned farmer living in Oregon's Willamette Valley, was arrested and convicted for allegedly inciting Indians to violence against a settler named Charles E. Pickett. Three years earlier, Saules had deserted the United States Exploring Expedition, married a Chinookan woman, and started a freight business on the Columbia River. Less than two months following Saules's arrest, Oregon's Provisional Government passed its infamous "Lash Law," banning the immigration of free black people to the region. While the government repealed the law in 1845, Oregon passed a territorial black exclusion law in 1849 and included a black exclusion clause in its 1857 state constitution. Oregon's territorial delegate also convinced the U.S. Congress to exclude black people from the 1850 Donation Land Act. In each case, Oregon politicians suggested the legacy of the Saules case by stressing the need to prevent black men, particularly sailors, from coming to Oregon and collaborating with local indigenous groups to commit acts of violence against white settlers.

This thesis explains the unusual persistence of black exclusion laws in Oregon by focusing on the life of Saules, both before and after white American settlers came to the region in large numbers. Black exclusion in Oregon was neither an anomalous byproduct of American expansion nor a means to prevent slavery from taking root in the region. Instead, racial exclusion was central to the land-centered settler colonial project in the Pacific Northwest. Prior to the Americanization of the Pacific Northwest, the region was home to a cosmopolitan and increasingly fluid culture that incorporated various local Native groups, exogenous fur industry workers, and missionaries. This was a milieu
\end{abstract}


made possible by colonialism and the rise of merchant capitalism during the Age of Sail, a period which lasted from the sixteenth to the mid-nineteenth century. This was also likely a world very familiar to Saules, who had spent his entire adult life aboard ships and in various seaports. However, the American immigrants who began arriving in Oregon in the early 1840 s sought to dismantle this multiethnic social order, privatize land, and create a homogenous settler society based on classical republican principles. And although Saules was born in the United States, American settlers, emboldened by a racialist ideology, denied most non-whites a place in their settler society. Furthermore, during the early decades of resettlement, white American settlers often felt vulnerable to attacks from the preexisting population. Therefore, many settlers viewed free black men like Saules, a worldly sailor with connections among Native people, as potential threats to the security of their nascent communities. 


\section{Acknowledgements}

I owe a large debt of gratitude to my advisor, Katrine Barber. Katy not only encouraged my interest in Oregon's black exclusion laws but also strongly suggested that I expand my undergraduate work into a graduate thesis. In addition, her state-of-the-art knowledge of Pacific Northwest history and settler colonialism was an invaluable resource. Finally, her enthusiasm for my work helped me maintain my focus even when my confidence started to waver.

Many other scholars at Portland State were also instrumental in shaping this work. Patricia Schechter was an early supporter of my work and introduced me to several exciting theoretical approaches to history. Darrell Millner's vast knowledge of Oregon history is matched only by his penetrating insights. Brian Turner's interest in historical geography, mapmaking, and military history was particularly helpful in developing my first chapter. Brian also put me in contact with Wayne E. Lee at the University of North Carolina at Chapel Hill, who provided a wealth of sources regarding the role of music in the maritime world.

I extend a special thanks to Liisa Penner at the Clatsop County Historical Society. She took time out of her busy schedule to prepare a folder of sources pertaining to James D. Saules. Many of these became crucial primary sources.

My family was also instrumental in this project. My parents, Robert and Gail Coleman, nurtured my interest in history as a child and never questioned my decision to "double-down" on a humanities education. Natalie Linn has been a tireless cheerleader 
and offered her generous support. I have also spent many hours conversing, attending classes, and sharing notes with my cherished "history buddy," Merritt Linn.

No one contributed to this work more than my wife, Jodi Coleman. She is the greatest partner, friend, sounding board, and editor I have ever known. Without her intelligence, patience, and support, I would still be stuck on page one. 


\section{Tables of Contents}

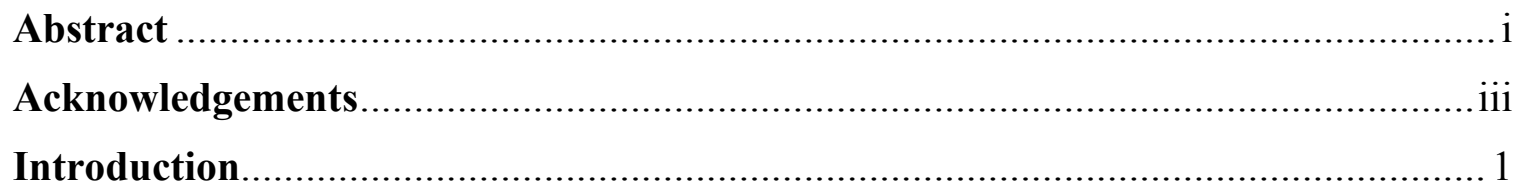

Chapter One

James D. Saules's Voyage to Oregon and American Imperialism in the Age of Sail ...... 20

Chapter Two

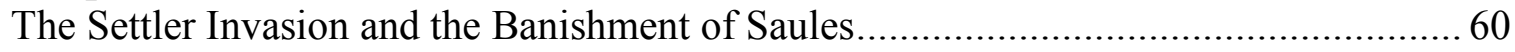

Chapter Three

Saules in Exile, The Oregon Question, and the Return of Black Exclusion ................. 103

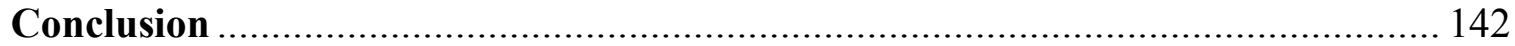

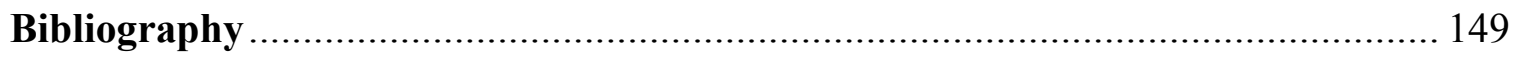




\section{Introduction}

The idea for this thesis came from a short article published in the November 22, 1964 edition of the Seattle Times entitled “Cape Disappointment's First Settler.” Cape Disappointment is located in Washington state on the northern side of the mouth of the Columbia River. The author, Pacific Northwest historian and journalist Lucile Saunders McDonald, began her article with a question: "What manner of man was the first to take up residence in Washington's southwest corner?"1 Ignoring the fact that a wellestablished Chinookan village had existed less than three miles from Cape Disappointment long before Americans first arrived, McDonald's answer was that the man, James D. Saules, was "an extraordinary character." "2 While McDonald's piece is fewer than 2,000 words, it is dense and thoroughly researched. She was clearly impressed by the unusual impact Saules had on Pacific Northwest history during the 1840s. She described how Saules, a sailor and ship's cook, deserted from a U.S. Navy exploring expedition in 1841 to settle in the Oregon Country. Three years after arriving, Saules moved to Oregon's Willamette Valley and was involved in the 1844 Cockstock Affair, an instance of violence between Native people and recently-arrived American settlers. McDonald claimed Saules was blamed by others for the incident and was soon arrested and convicted for inciting Natives to violence against a fellow settler. Indian subagent Elijah White then ordered Saules to relocate from the Willamette Valley to Cape

\footnotetext{
${ }^{1}$ Lucile McDonald, “Cape Disappointment's First Settler," The Seattle Times, November 22, 1964, Sunday edition, sec. Sunday magazine, 4.

2 Ibid. Although McDonald refers to him as "James D. Saule," in the interest of consistency, I will refer to him throughout as James D. Saules. That is also the spelling of the name given in the letter written by Saules to Elijah White in 1844.
} 
Disappointment, where, in 1845 , he found himself in the middle of both a land dispute and long-simmering tensions between the United States and Great Britain. The outcome of this chain of events was again displacement. Yet despite ten years of high visibility in the region, McDonald puzzled over the fact that Saules vanished from the historical record after 1851 .

Although she did not focus on it specifically, McDonald noted another aspect of Saules that caused him to stand out in the Oregon Country during the 1840s: He was a black man. However, McDonald shied away from confronting the issue of race directly. Her tone toward Saules was neutral but respectful. While she referred to Cockstock, a Wasco Native, as a "redskin," she identified Saules as "a Negro," which was polite racial terminology at the time she wrote the article. But despite her depth of research, McDonald failed to mention the historical detail for which Saules is arguably best known and the reason I tracked down her article. Immediately following Saules's arrest and exile in June of 1844, Oregon's provisional government passed its infamous "Lash Law." The law forbade free black people from coming to and residing in the part of the Oregon Country located south of the Columbia River. At this time, the Oregon Country was a vast region that encompassed all of present-day Oregon, Washington, Idaho, and British Columbia, as well as parts of Montana and Wyoming. Those who remained in the region would be subjected to flogging. The wording of subsequent racist legislation in Oregon, as well as the rhetoric used to support it, also suggested the strong impression Saules made on American settlers in the region. Advocates for black exclusion repeatedly expressed the need to prevent black sailors like Saules from inciting local Native 
populations to violence against white settlers. That McDonald failed to mention this is somewhat surprising since historian Frances Ford Victor had explored the link between Saules and black exclusion as early as 1888 in Hubert Howe Bancroft's well-known History of Oregon.

Nearly a century earlier, in 1875 , a very different profile of Saules appeared in Bret Harte's Overland Monthly, entitled "Pioneer Nig Saul." The piece, written by whaleman turned naturalist Charles Melville Scammon, was based on limited research. Scammon, who spent some time in Oregon in the mid-to-late nineteenth century, apparently relied on "an old note-book kept by some odd genius,", as well as the recollections of Oregon residents to craft a whimsical but unreliable portrait of Saules. Yet unlike McDonald, Scammon made frequent mention of Saules's race. As such, the article is a mélange of minstrel show and maritime stereotypes. He depicted Saules as a hard-drinking, fiddle-playing, sexually promiscuous "son of Africa" who spoke in thick southern black dialect. ${ }^{4}$ He described how a local Chinook woman enticed Saules to desert his crew and claimed that he eventually "took himself a wife in nearly every Indian village along the banks of the Columbia." ${ }^{5}$ Yet what intrigued Scammon most about Saules was that he was the captain of the Calapooia, "the first vessel built in the country that hoisted the American flag and plied permanently on the Columbia."6 But Scammon, like McDonald, made no mention of Saules's exile from the Willamette Valley or the 1844 black exclusion law he inspired. In fact, according to Scammon, "Though at the

\footnotetext{
${ }^{3}$ Charles Melville Scammon, "Pioneer Nig Saul," in The Overland Monthly, ed. Bret Harte (A. Roman \& Company, 1875), 273.

${ }^{4}$ Ibid.

${ }^{5}$ Ibid.

${ }^{6}$ Ibid., 274.
} 
period we are writing of there was no legal protection for Blacks in the [Oregon] Territory, Saul had nothing to fear."7 Although this was clearly incorrect, Scammon's ignorance regarding the matter is somewhat more understandable than McDonald's given the paucity of historical sources available to him.

Shortcomings aside, McDonald and Scammon were the first and, up to this point, only writers to move Saules from the margins of the historical record and place him at the center of their narratives. This is exactly what I intend to do in this thesis, although for different reasons. Like McDonald, I am struck by the impact Saules had on local (and perhaps even national and international) history during the period American settlers colonized Oregon. And like Scammon, I am fascinated by how Saules attempted to navigate, both literally and figuratively, the shifting cultural landscape of the Pacific Northwest in the mid-nineteenth century. But if one wants to truly understand any facet of Oregon or American history, the subject of race cannot be ignored or trivialized. Saules was a well-traveled man of considerable talents and daring, but what made him "an extraordinary character" in the Oregon Country of the 1840s had as much to do with how he appeared to others than any of his actions. One key reason he appears so often in the historical record is that he was unmistakably black in a region where black people were extremely rare. Secondly, he was a highly mobile sailor in Oregon during a period in which movement across space, either by land or water, was difficult. Finally, he married a Native woman with whom he started a family. While this was common among Euro-American men associated with the fur trade, a black man associating with Native people in this manner carried special and dangerous significance for many American

\footnotetext{
${ }^{7}$ Ibid., 273.
} 
settlers in the 1840s. The combination of these three factors attracted the attention of Anglo-American authority figures, many of whom contributed to the written historical record of the period.

By focusing on Saules and his experiences in the region, I will demonstrate how black exclusion in Oregon was neither an anomalous byproduct of American expansion nor a means to prevent slavery from taking root in the region. Instead, racial exclusion, meaning the removal of non-whites from shared social spaces, was actually central to the land-centered settler colonial project in the Pacific Northwest. Saules was a black man living in the region in the 1840 s, a time in which thousands of American immigrants arrived. They sought to dismantle the preexisting multiethnic social order, privatize commonly held land, and create a homogenous settler society based on classical republican principles. But most settlers shared a racialist ideology and used race, as opposed to national origin or religion, as shorthand to determine which previous inhabitants would be included and which would be excluded. Therefore, a Scottish or French-Canadian Catholic fur trader could theoretically join the settler society, but a black yeoman farmer born in the United States could not. As for the region's indigenous population, the common assumption among American settlers was that they were an inferior race destined for extinction. But Saules, as a black man, was an outlier. He was neither racially marked as colonizer nor colonized. There was also no indication in the antebellum United States that Saules was a member of a vanishing race, as the population of both free and enslaved black people increased significantly between 1830 and 1840 . And according to the "one-drop" rule, the children he had with his Chinookan wife were 
also racialized as black. Furthermore, as a free man, Saules violated what many Americans viewed as the natural condition of a black person, as that of a slave. Instead, as a worldly sailor with connections among Native people, American settlers in Oregon viewed him, and others like him, as a source of potential resistance and therefore an existential threat to their nascent settler society.

Historian Eugene H. Berwanger was among the first scholars to critically address Oregon's legacy of black exclusion in his 1967 book, The Frontier Against Slavery: Western Anti-Negro Prejudice and the Slavery Extension Controversy. Berwanger argues that the antislavery sentiment of most western settlers had little to do with moral reservations about slavery. Instead, according to Berwanger, "Anti-Negro midwesterners presumed that slavery was the prerequisite for a large free Negro population; therefore, one means of preventing the residence of free Negroes was to prohibit slavery." ${ }^{8}$ This argument is persuasive regarding the Old Northwest (Illinois, Indiana, Ohio, and Iowa), the Border States (Missouri, Tennessee, and Kentucky), and the Great Plains (Kansas and Nebraska), as these states were either in close proximity to slave states, or, as in the case of the Border States, already had a sizable population of enslaved blacks. Many white residents in these areas worried about runaway slaves reaching their communities, or the eventual emancipation of slaves resulting in the mass immigration of free blacks.

However, this argument has less explanatory power in regards to Oregon's insistence on black exclusion. It is true that most white Americans in the nineteenth century believed that non-whites were biologically inferior. Yet while millions of Americans relocated to

\footnotetext{
${ }^{8}$ Eugene H. Berwanger, The Frontier against Slavery: Western Anti-Negro Prejudice and the Slavery Extension Controversy (University of Illinois Press, 2002), 98.
} 
the western half of North America in the mid-to-late nineteenth century, black exclusion laws were actually rare in American West. Furthermore, few, if any, black exclusion advocates ever voiced the belief that a mass exodus of free or enslaved black people to Oregon was likely. Furthermore, despite the anti-slavery disposition of most Oregon settlers, the few slaveholders who did bring their slaves with them on the overland trail were either ignored or tolerated. ${ }^{9}$ On the other hand, Berwanger does identify Saules as the "immediate impetus" for black exclusion in Oregon. ${ }^{10}$

Saules has also received some attention from scholars of black history and black exclusion in Oregon specifically. Elizabeth McLagan's book Peculiar Paradise: A History of Blacks in Oregon 1788-1940 contains a brief biographical sketch of Saules, but she does not clearly link him with black exclusion. In his 1982 article "Slaves and Free Men: Blacks in the Oregon Country, 1840-1860” historian Quintard Taylor provides a short but more scholarly examination of Saules. Taylor correctly identifies Saules' role in inspiring the first black exclusion law but gets several facts wrong when describing the events that led up to the passage of the law. For instance, there is no actual evidence for his claim that white settlers blamed Saules for the Cockstock Affair.

By far the most thorough study connecting Saules to black exclusion in Oregon is Thomas McClintock’s 1995 article “James Saules, Peter Burnett, and the Oregon Black Exclusion Law of June 1844." McClintock's piece is a fine summary of the events that preceded the first black exclusion law and, unlike Berwanger, McClintock argues that the

\footnotetext{
${ }^{9}$ Historian Gregory Nokes has examined the challenges faced by enslaved blacks in Oregon who tried to gain their freedom in a supposedly free territory. See R. Gregory Nokes, Breaking Chains: Slavery on Trial in the Oregon Territory (Corvallis, OR: Oregon State University Press, 2013).

${ }^{10}$ Berwanger, The Frontier against Slavery, 81.
} 
racism of settlers was not enough to explain both the rush to pass the first black exclusion law and its severity. Unfortunately, despite featuring Saules's name in the title, McClintock offers very little background on him. Instead, he pays far closer attention to the actions and rhetoric of Peter Burnett and other white settlers than Saules himself. And like Taylor, he overemphasizes the supposed link between Saules's role in the Cockstock Affair and the 1844 law. Instead, he insists that the first black exclusion law is best explained as the reaction of Oregon's provisional government to a dramatic sequence of events involving the Cockstock Affair and Saules's arrest for inciting Native people to violence. These events led white settlers to conclude that the existence of free black people in the region would incite Native unrest. According to McClintock, "That this fear produced the black exclusion law and explains both the haste in which it was passed and the harshness of its enforcement provision is supported by later events." "1

While I agree with McClintock's assessment that the imported racism of American settlers is not enough to explain unusual prevalence of black exclusion laws in Oregon, I find his argument as limited as Berwanger's. ${ }^{12}$ McClintock places too much emphasis on a specific series of events without adequately investigating the deeper historical reasons for why the provisional government responded the way that it did. This is not to suggest that these events were not important, as I will devote significant space to them in this thesis. But McClintock never approaches the question of why the presence of

\footnotetext{
${ }^{11}$ Thomas C. Mcclintock, "James Saules, Peter Burnett, and the Oregon Black Exclusion Law of June 1844," The Pacific Northwest Quarterly 86, no. 3 (July 1, 1995): 129.

12 This is not to suggest that black exclusion laws were unheard of in antebellum America, even in slave states. For example, Virginia's slave codes often required manumitted slaves to leave the state. See Eva Sheppard Wolf, Race and Liberty in the New Nation: Emancipation in Virginia from the Revolution to Nat Turner's Rebellion (Louisiana State University Press, 2009).
} 
two free black men in the Willamette Valley made the white American settlers who comprised the provisional government feel so insecure. This is because McClintock, like Berwanger and other scholars of black exclusion, focuses almost exclusively on the American immigrants and their values and ignores what the Oregon Country and, more specifically, the Willamette Valley was like prior to when the American immigrants began to arrive in large numbers. I contend that racial exclusion is best understood through an examination of the shifting and overlapping modes of colonialism in the region during the mid-nineteenth century.

While many American settlers envisioned the region as containing free land for the taking, it was neither an empty space nor an arcadian paradise. Instead, it had been thoroughly transformed by colonial contact, both direct and indirect. The preexisting population, although small, was culturally complex, containing not only various indigenous peoples, but also the ethnically diverse workforce of the fur industry and missionaries, both Catholic and Protestant. And when the first American settlers left Independence, Missouri in 1843, the United States was still a maritime nation. While the Oregon Country was remote from centers of power in United States and Great Britain, sailing ships linked it to the various multiethnic seaports made necessary by the exigencies of merchant capitalism during the Age of Sail. This was the maritime global market network that brought Saules to the region and would presumably continue to bring other men of various ethnicities. What distinguished these forms of economic and religious colonialism from the settler colonialism that came later was that, despite the fact that those with leadership positions in the fur industry, as well as missionaries, often 
exploited or belittled the Native, Hawaiian, and black people living in the region, the success of their projects required their involvement. The American settlers, on the other hand, did not seek the labor of non-whites, they wanted their land. Therefore, the success of the settler colonialist project required their removal. This was ultimately accomplished through various legal mechanisms backed by the threat of state violence. These included official land surveys, treaties, and racial exclusion laws.

An important aspect of my argument is that the black exclusion laws of 1844 and 1849 were conceived and passed when American settlers in Oregon felt most vulnerable. Most had traveled incredible distances overland to arrive in an ethnically diverse region they did not fully understand. When the first large American wagon train arrived, the overlanders had little leverage in the region and were still largely dependent on the preexisting population for their survival. While the region held great agricultural potential, many American cultivators struggled to produce a viable yield on their claims. Fur traders extended credit to the American immigrants and local Native people often worked as hired hands on their nascent farms. Yet the settlers also understood that their desire for more land would be met with resistance from those already living on it, or those who used it as hunting and gathering grounds. Tensions over competing land claims also emerged between the recently arrived Americans, Methodist missionaries, and the local management of the Hudson's Bay Company (HBC). At the same time, settlers feared that disenfranchised free blacks would cause trouble for settlers or, even worse, collaborate with the Native population to foment an uprising. While this might seem absurd in hindsight, this was not without precedent. In the 1830s, escaped slaves joined 
forces with the Seminoles in Florida to resist attempts by the United States to remove them to reservations. This resulted in a costly seven-year conflict between the U.S. Army and the Seminole and black fighters. In 1847, in the aftermath of the Whitman Massacre, settlers again feared for their safety and legislators called for black exclusion as a means to neutralize potential threats.

My insistence on placing racial exclusion laws within the context of a colonial shift in the Oregon Country was largely informed by the work of historian Gray H. Whaley. In his 2010 book, Oregon and the Collapse of Illahee: U.S. Empire and the Transformation of an Indigenous World, 1792-1859, Whaley describes how the various Chinookan peoples of the lower Columbia River incorporated Euro-American newcomers associated with the fur industry into their trade and kinship networks. He refers to the culturally hybridic world that emerged from this colonial contact as Illahee, a Chinookan word meaning land, soil, and home. ${ }^{13}$ For Whaley, Illahee was "a composite Native realm with multiple meanings that changed over time in relation to Indian peoples' experiences with colonization."14 According to Whaley, "The planned and unplanned effects of the fur trade, missions, and settler colonialism created a dynamic and often dangerous world through which the Native peoples had to navigate." $"$ Whaley manages to tell a familiar story in a new way by placing Chinookan peoples at the center of his narrative and recasting the Oregon Trail as the site of an invasion. I intend to accomplish a similar historical reversal by focusing on Saules and showing how he too

\footnotetext{
${ }^{13}$ Gray H. Whaley, Oregon and the Collapse of Illahee: U.S. Empire and the Transformation of an Indigenous World, 1792-1859 (University of North Carolina Press, 2010), 3.

${ }^{14}$ Ibid., 230.

15 Ibid.
} 
steered a course through the "dynamic and often dangerous world" of the Oregon Country in the 1840 s.

Despite the strengths of his book, I find Whaley's use of the term Illahee somewhat problematic, since it is an ahistorical term that Chinookan peoples never actually used to refer to the Oregon Country. As far as historical concepts are concerned, I find Richard White's notion of a "middle ground" more useful in describing the dynamics of the lower Columbia River region and Willamette Valley prior to Americanization. According to White, "The middle ground is the place in between: in between cultures, peoples, and in between empires and the nonstate world of villages. It is a place where many of the North American subjects and allies of empires lived."16 A middle ground is not a place in which a dominant group absorbs or acculturates a subordinate group. Instead, it is a confusing and often violent place in which, through accommodation and mutual dependence, new cultural meanings, values, and practices are formed. White used the term to describe the common world shared for over 150 years by French-speaking fur industry workers and Algonquians in the region around the Great Lakes. While the existence of a middle ground in the Pacific Northwest is measured in decades rather than centuries, I insist that it can be applied to the energetic world forged by Chinookan peoples, fur industry workers, and missionaries. ${ }^{17}$

\footnotetext{
${ }^{16}$ Richard White, The Middle Ground: Indians, Empires, and Republics in the Great Lakes Region, 1650 1815 (Cambridge University Press, 2011), x.

${ }^{17}$ The notion that the Oregon Country was a cultural "middle ground" during the fur trade period (1820s1840s) is somewhat controversial among historians. Regarding the Oregon Country, Gray H. Whaley insists that "nothing as elaborate or coherent as a syncretic middle-ground culture developed." Yet Whaley also admits that "colonials and Natives did have to meet each other "halfway' with their diplomacy." Nathan Douthit, on the other hand, argues that the Oregon Country was a middle ground, even though it "lacked the depth of cultural exchanges described by White." I agree with Douthit's assessment that even though Oregon's middle-ground status was comparatively brief and had limited reach, it "involved trade,
} 
Unlike Whaley's Illahee, White's notion of the middle ground stresses the creative aspects of colonial contact and the market revolution as much as it does the destructive ones. In this thesis, I will stretch the notion of the middle ground to include other sites fostered by merchant capitalism and economic colonialism during the Age of Sail, including the seaports and deep-sea vessels of the maritime world. It was in these various middle grounds that Saules found something resembling a home. Yet White claims that the middle ground in the Great Lakes region was gradually destroyed with the rise of the American Republic in the late seventeenth and early nineteenth century, as Native people were no longer powerful enough to force the Americans to accommodate them. The outcome, according to White, was that the Americans reinvented Native people as alien and other. Something similar happened in the Oregon Country, which, due to its exposure to the maritime trade, was even more ethnically diverse than the Great Lakes region. To dismantle the middle ground that existed in Oregon, American settlers had to draw and enforce a color line that divided the included from the excluded. Saules found himself on the wrong side of that line.

The sections of this thesis that focus on the arrival of American settlers rely heavily on recent scholarship regarding settler colonialism. In particular, the works of Patrick Wolfe, Lorenzo Veracini, and James Belich have provided an invaluable theoretical framework from which I derived much of my argument. In a sense, they have gone beyond the more local histories of Whaley and White to analyze settler colonialism

sexual relations, diplomatic negotiations, and legal issues similar to those that existed on the seventeenthand eighteenth century colonial frontier described by White." See Whaley, Oregon and the Collapse of Illahee, 57. Nathan Douthit, Uncertain Encounters: Indians and Whites at Peace and War in Southern Oregon, $1820 s-1860 s, 2$. 
as a global (and ongoing) invasion of indigenous spaces. For instance, Belich argues that the early nineteenth century witnessed the emergence of a new "discourse of emigration" or "mass ideology" in which many in the Anglophone world felt compelled to travel unprecedented distances to dispossess indigenous peoples and install conservative settler societies modeled on the ones they left. ${ }^{18}$ This marked a change from previous forms of colonialism in which colonists usually sought to incorporate indigenous people (often temporarily) into their economic ventures. And according to Belich, "It was settlement, not empire that had the spread and staying power in the history of European expansion." ${ }^{19}$ Much of the success of settler colonialism was due to it being a massive, "bottom-up" movement. The American settlers who came to Oregon in the early 1840 s were not organized or sponsored by the United States government. They were organized along kinship lines rather than national affiliation. By the time the nation-state stepped in, much of the colonial work of building infrastructure, developing statecraft, and dispossessing Native people was already completed. Because of this, Belich argues, indigenous peoples "could cope with normal European colonization; it was the explosive colonization that proved too much for them."20

The settler invasion also proved too much for Saules, demonstrating the strong connection between racial exclusion and settler colonialism. My use of the term "race" refers to a fluctuating social and historical idea or discourse--rather than any kind of biological phenomenon--in which various meanings are attached to different kinds of

\footnotetext{
${ }^{18}$ James Belich, Replenishing the Earth: The Settler Revolution and the Rise of the Anglo World (Oxford University Press, 2011), 149.

${ }^{19}$ Ibid., 23.

${ }^{20}$ Ibid., 181 .
} 
bodies. According to sociologists Michael Omi and Howard Winant, "[T]he concept of race continues to play a fundamental role in structuring and representing the social world. ${ }^{, 21}$ This is particularly true of social groups, like nineteenth-century American settlers, who ascribed racial characteristics onto others as a pretext for domination. Collette Guillaumin argues that race emerged as both a scientific and legal status in the post-Enlightenment nineteenth century as a result of the "interaction between the economies of colonialism, industrial growth, and progress in the natural sciences.",22 Therefore, what Patrick Wolfe refers to as "the organizing grammar of race" came of age at the same time as modern settlers colonialism, and race was either a qualification or disqualification for citizenship in most settler societies, Oregon included. ${ }^{23}$ Wolfe contends that race, as a means of inclusion and exclusion, "becomes activated in the context of the threat of social space having to be shared with the colonized." ${ }^{24}$ But Wolfe also argues that, for many white Americans, free black men like Saules existed in a disturbingly grey area between colonizer and colonized: "[T]he presence of Black people who were not slaves (though by no means free in the sense that White people were) produced all sorts of legal and ideological anomalies for a society that was premised on an equation between blackness and slavery.",25

This work is more microhistory than a biography. A microhistory reduces its scale to focus on one person, or a small group of people, who, in Georg G. Iggers's words, “are

\footnotetext{
${ }^{21}$ Michael Omi and Howard Winant, Racial Formation in the United States: From the 1960s to the 1990s (Psychology Press, 1994), 55.

${ }^{22}$ Colette Guillaumin, Racism, Sexism, Power and Ideology (Routledge, 2002), 61.

${ }^{23}$ Patrick Wolfe, "Settler Colonialism and the Elimination of the Native," Journal of Genocide Research 8 , no. 4 (2006): 387.

${ }^{24}$ Patrick Wolfe, "Race and Racialisation: Some Thoughts," Postcolonial Studies 5, no. 1 (2002): 59.

${ }^{25}$ Ibid., 58.
} 
not viewed as part of a crowd but as individuals who must not be lost either within world historical processes or in anonymous crowds. ${ }^{, 26}$ To do a proper biography of Saules, I would need more sources that provide his perspective on events. Aside from one letter ostensibly written by Saules, most of my sources come from white authority figures and elites. This suggests one reason why marginalized and non-elite people seldom have biographies written about them. However, the fact that Saules did attract so much attention from white elites in Oregon is alone worthy of examination. Microhistory emphasizes the experiences and activities of ordinary and subaltern people, people whom more traditional historians often generalize about or ignore altogether. I am attracted to the methods and reduced scale of microhistory because they vividly reveal both the possibility and limits of human agency in the face of institutional restraints. Furthermore, according to Charles W. Joyner, microhistorians are most interested in "asking large questions in small spaces. ${ }^{27}$ Therefore, by focusing on what made Saules a dangerous outlier in Oregon, I can connect him to larger social and historical changes. This approach has its risks, as there are stretches of this work in which Saules seems to disappear from my narrative. But I believe it is necessary to frequently pull the historical lens back to adequately reconstruct the social, cultural, and political context of antebellum America and the maritime world.

One of the purposes of doing a microhistory is to try to gain insight into everyday lives and how various institutions and structures of power affected ordinary people. Yet

\footnotetext{
${ }^{26}$ Georg G. Iggers, Historiography in the Twentieth Century: From Scientific Objectivity to the Postmodern Challenge, 2nd ed. (Wesleyan, 2005), 103.

${ }^{27}$ Charles W. Joyner, Shared Traditions: Southern History and Folk Culture (University of Illinois Press, 1999), 1.
} 
representatives of these same institutions were responsible for most of my sources. This poses the daunting question of whether it is even possible to recover the voices of nonelites. Throughout this work I have attempted to read my "top-down" sources (government reports, legal documents, public journals, congressional records, etc.) against the grain by approaching them critically and skeptically. I have also tried to address the numerous silences in the historical record through historically informed speculation, or by borrowing the macrohistorical techniques of social history. In each of these cases I have tried to remain transparent when doing so. However despite my best efforts, I recognize that this work, like the work of Lucile McDonald and Charles Melville Scammon, will probably reveal as much about my own interests and biases as it will about the life of Saules.

In chapter one, I describe how James D. Saules came to the Pacific Northwest and what he found when he arrived. My focus is on the maritime world of the early to midnineteenth century and how an insatiable demand for maritime labor allowed black sailors like Saules to find employment among the multiethnic crews of deep-sea sailing ships. In 1838, Saules joined the United States Exploring Expedition, a large-scale U.S. Navy exploring and surveying mission that logged over 80,000 nautical miles. The mission was intended to gather scientific knowledge, expand the nation's commercial horizons, and perform a thorough survey of the Pacific Northwest. I will also discuss the political context for the mission, which was conceived during a period in which politicians debated over whether the United States should be a trade-oriented maritime nation or look to its interior for land and resources. And while the mission was stripped 
of military trappings, its commanders understood its imperialistic implications and sometimes subjected indigenous peoples to brutal violence. In June of 1841, the U.S.S. Peacock, the ship on which Saules served, was wrecked near present-day Astoria, Oregon. While most of the crew rejoined the expedition, Saules was among those who remained in the region. Saules soon married a Chinookan woman and adapted to the heterogeneous culture of the lower Columbia River region.

In chapter two, I examine how, beginning in late 1843, the arrival of thousands of American farm families dramatically altered race relations in the region. While Saules initially attempted to adapt to the new settler society, he eventually found himself embroiled in regional tensions that threatened to explode into full-scale violence. These tensions were largely due to the American immigrants imposing a foreign system of laws on both the Euro-American and Chinookan people living in the Willamette Valley, as well as Native groups living in the surrounding areas. The purpose of these laws was to legitimate the land claims of American settlers, as well as to protect their private property. Some Americans also feared that those who belonged to the preexisting population, such as representatives of the Hudson's Bay Company, might use the Native population to undermine their fledgling community. I will focus on two notable incidents Saules was involved in during this period, the Cockstock Affair and the Saules-Pickett dispute. Following the latter, Indian subagent Elijah White essentially forced Saules to leave the Willamette Valley and resettle near the mouth of the Columbia. Shortly after his exile, Oregon's provisional government, barely one year old, passed the "lash law," which banned all black people from coming to and settling in the region. 
In chapter three, I explain how passage of the first black exclusion law did not result in the end of Saules's time in Oregon. Instead, as settlers' fears of attack from Native people subsided, so did the provisional government's insistence on black exclusion. Saules soon became a part of the community of Clatsop Plains near the mouth of the Columbia, where he worked as cook, musician, and river pilot. During this same period, tensions increased between the United States and Great Britain over the possession of the lower Columbia River region. Yet even as the two powers negotiated thousands of miles away, the dispute over Oregon affected Saules personally on at least two occasions, one of which again ended in displacement. Less than one year after the United States emerged victorious in 1846, the Whitman Massacre again aroused fears that the fledgling American community was vulnerable to attacks from Natives people. This not only resulted in Oregon becoming a territory in 1848, but the new Oregon legislature cited potential Native violence as a justification for a new black exclusion law passed in 1849. While the law did not apply directly to Saules, the language of the bill strongly suggested the impression he had made on white settlers. In an even more decisive move, Oregon politicians convinced the U.S. Congress to pass the 1850 Donation Land Act, which encouraged white married couples to relocate to Oregon with the promise of generous land grants. However, the bill was itself a racial exclusion law that made it impossible for Saules and most other non-white people to establish land claims. 


\section{Chapter One: James D. Saules's Voyage to Oregon and American Imperialism in the Age of Sail}

James D. Saules first appears in the historical record in 1839 as a crewmember of the United States Exploring Expedition, commonly referred to as either the U.S. Ex. Ex. or the Wilkes Expedition after its commander, U.S. Navy Lieutenant Charles Wilkes. ${ }^{28}$ Saules traveled thousands of miles with the expedition, visited places few Americans even knew existed, and eventually arrived in the ethnically diverse lower Columbia region of the Pacific Northwest. Yet the fact that a black man like Saules took part in a U.S. Navy expedition during the antebellum period was no anomaly. The demand for maritime labor during the Age of Sail provided free black men with an opportunity to earn a living and provide for their families and resulted in the development of a heterogeneous culture aboard ships and at seaports. The expedition itself was a product of an earlier form of American colonialism that was later overshadowed by the settler colonial phenomenon known as Manifest Destiny. The U.S. Ex. Ex. was a "top-down" operation instigated by the federal government for the purpose of commerce and exploitation of natural resources rather than the resettlement of distant lands. The expedition accomplished its aims more through surveying, cartography and the collection of scientific data than a display of firepower. Which is not to suggest that the expedition's leaders shied away from extreme violence when they deemed it necessary. But the arrival of the U.S. Ex. Ex. in the Oregon Country in 1841 signaled a shift in the mission's

\footnotetext{
${ }^{28}$ Charles Wilkes, Narrative of the United States Exploring Expedition: During the Years 1838, 1839, 1840, 1841, 1842. in Five Volumes with Thirteen Maps, 1850, lii.
} 
objective, as the expedition's backers, and Saules himself, envisioned the Pacific Northwest as an ideal place for Americans to relocate.

The expedition was a U.S. government authorized voyage of discovery unprecedented in both scope and objective. It lasted for four years, traveled over 80,000 miles, and consisted of six ships and over 400 crewmembers, including naturalists, botanists, mineralogists, sketch artists, a taxidermist, and a philologist. Wilkes's assignment included two attempts to reach the still-undiscovered continent of Antarctica, a thorough survey of the islands of the South Pacific, and a thorough reconnoitering of the Pacific Northwest. While Saules joined the expedition in the summer of 1839 at Callao, Peru, the mission actually began nearly one year earlier on August 18, 1838, when it disembarked from the U.S. naval base at Norfolk, Virginia.

The historical background of the U.S. Ex. Ex. reveals the shifting nature of American foreign policy and imperialism in the first half of the nineteenth century. The expedition occurred at a point in which the United States was transitioning from a maritime nation that relied primarily on overseas commerce to a continental nation in which resources could be extracted from North America's vast interior. During this same period, the nation underwent concomitant political changes. The expedition was conceived at a time when Andrew Jackson staged a long challenge to President John Quincy Adams, a New Englander and former diplomat with strong support from northeastern commercial class of bankers, manufacturers, and land speculators. Unlike Adams, Jackson often presented himself as a westerner whose political sensibility was forged far from northeastern corridors of power; his new Democratic party drew 
impressive support from white farmers, artisans, and laborers in the West and South. Such people later comprised the majority of those who traveled overland to resettle the Pacific Northwest.

Although Wilkes himself described the U.S. Ex. Ex. as the first naval mission "fitted by national munificence for scientific objects," 29 the expedition's chief aims were commercial. The first sentence of U.S. Secretary of the Navy James Kirke Palding's instructions to Wilkes refers to "the important interests of our commerce embarked in the whale-fisheries, and other adventures in the great southern ocean..."30 The United States had the largest whaling fleet in the world and information gathered from the mission would provide American whalemen with reliable maps of the Pacific Ocean. ${ }^{31}$ Its backers also hoped the expedition would unearth ample sources to supply burgeoning markets in fish, seals, sandalwood, and feathers. ${ }^{32}$

Like Lewis and Clark’s Corps of Discovery (1804-1806), Wilkes was charged with the task of collecting data and samples pertaining to flora, fauna, and indigenous peoples. ${ }^{33}$ However, Paulding's instructions to Wilkes forbade he and his crew from harming Native people or interfering with indigenous cultures. Paulding insisted that the expedition "is not for conquest, but discovery." ${ }^{34}$ They were instead encouraged to promote national interests by leaving a positive impression of the United States.

\footnotetext{
29 Ibid., iv.

${ }^{30}$ Ibid., xxv.

${ }^{31}$ Nathaniel Philbrick, Sea of Glory: America's Voyage of Discovery: the U.S. Exploring Expedition, 18381842 (Penguin, 2004), 118.

32 William Ragan Stanton, The Great United States Exploring Expedition of 1838-1842 (Berkeley: University of California Press, 1975), 16.

33 Ibid., 200.

${ }^{34}$ Wilkes, Narrative of the United States Exploring Expedition, 1850, xxviii.
} 
Despite such pleas for moderation, the expedition's backers understood its imperialist implications. According to Paulding, its primary objective was "to extend the empire of commerce and science. ${ }^{35}$ President John Quincy Adams first proposed a maritime expedition in 1825 , claiming that if United States failed to match the maritime exploits of Great Britain, France, and Russia, they would be doomed to "perpetual inferiority. ${ }^{, 36}$ Adams was a passionate nationalist who believed a strong central government was crucial to promote U.S. interests in commerce, military power, manufacturing, and science. Adams was also an early proponent of westward expansion. For instance, Adams was central to the crafting of the Convention of 1818, which established the joint occupation of the Oregon Country by the United States and Great Britain. He made his reasons clear in an address to Congress: "I want the Oregon country for our western pioneers. ${ }^{, 37}$ However, Adams did not envision the Pacific Northwest as part of the United States, but instead as an independent republic with strong diplomatic and trade ties to the United States. ${ }^{38}$ The idea of overland expansion was also highly questionable in the early nineteenth century, since the United States was still primarily a maritime nation dependent on overseas trade. It was also only beginning to make the necessary internal improvements to exploit the wealth of its interior, such as the 1825 completion of the Erie Canal. Instead, Adams intended the expedition as an audacious projection of U.S. military and commercial power.

\footnotetext{
${ }^{35}$ Ibid.

${ }^{36}$ Stanton, The Great United States Exploring Expedition of 1838-1842, 4-5.

${ }^{37}$ Earl Spencer Pomeroy, The Pacific Slope: A History of California, Oregon, Washington, Idaho, Utah, and Nevada (University of Nevada Press, 1965), 58.

${ }^{38}$ Ibid.
} 
The election of Andrew Jackson in 1828 sounded the death knell for this early version of U.S. Ex. Ex., as the new president quickly abandoned the idea of a major voyage of discovery. Jackson rode a populist wave of antipathy toward northeastern elites and Adams' vision of a robust federal government. Such ire was directed toward politicians such as Daniel Webster, who urged the federal government to develop overseas commerce and once derided agrarian republicans for seeing the United States as "as a great land animal...who has nothing to do with the ocean, but to drink at its shores or sooth its slumbers by the noise of its waves. ${ }^{, 39}$ U.S. Representative Albert Gallatin Hawes, a Jacksonian Democrat, referred to the proposed expedition as a "chimerical and hairbrained notion" that required vast sums of money to be "wrested from the hands of the American people. ${ }^{, 40}$ Democratic Senator Robert Y. Hayne of North Carolina, the Chairman of the Committee on Naval Affairs, attacked the expedition on the grounds that government funds were better spent on developing agriculture and that commerce and science could be "safely left to the enterprise of individuals." ${ }^{41}$ Haynes also feared the expedition would lead to the United States to develop "unnecessary connections abroad" or the establishment of an overseas colony requiring massive amounts of government spending to defend. ${ }^{42}$

Jackson, like many Americans in the early nineteenth century, shared these isolationist instincts regarding overseas exploration. During the presidential campaign, he portrayed Adams as an educated Old World-style aristocrat with diplomatic and cultural

\footnotetext{
39 “An Address Delivered By Daniel Webster," Granite Monthly: A New Hampshire Magazine, 1882, 9.

${ }^{40}$ Stanton, The Great United States Exploring Expedition of 1838-1842, 33.

${ }^{41}$ Ibid., 25.

${ }^{42}$ Ibid.
} 
ties to Europe. Instead, Jackson, the first president not born and raised on the eastern seaboard, saw America's future in the West. He largely rejected the notion of an American economy fueled by federally financed industrialization and overseas commerce. According to historian Richard Hofstadter, “Jackson’s politics chiefly resembled the agrarian republicanism of the old school, which was opposed to banks, public debts, paper money, high tariffs, and federal internal improvements." Jackson was deeply influenced by Thomas Jefferson's "Empire of Liberty" and believed the nation should be dominated by Anglo-Protestant farmers, small merchants, and artisans working in its interior. Furthermore, Jackson, a proponent of slavery and Indian removal, believed a racially homogenous citizenry was necessary to avoid internal division and sectional strife.

By the end of his second term in 1836, Jackson, who was as nationalistic and expansionistic as Adams, had warmed to the idea of the expedition. He believed that the United States should be at least the equal of other nations in terms of scientific knowledge. ${ }^{43}$ Jackson also saw the economic value of exploration and surveying for the United States and was resigned to the fact that the United States continued to rely on overseas commerce. For instance, in 1832, he sent two naval ships-one of which, the U.S.S. Peacock, was later Saules's home for two years - to the Far East to make treaties benefiting U.S. trading and shipping interests. ${ }^{44}$ Jackson also became increasingly interested in the West Coast of North American and tried to purchase San Francisco Bay

\footnotetext{
43 Ibid., 29.

44 Ibid.
} 
from Mexico in $1835 .{ }^{45}$ On May 14, 1836, after a contentious debate, the U.S. Congress passed an amendment to the Naval Appropriations Bill authorizing Jackson to "send out a surveying and exploring expedition to the Pacific Ocean and South Seas. ${ }^{, 46}$

Two Missouri Democratic senators, Thomas Hart Benton and Lewis F. Linn, voted for the bill. Both were extremely passionate about westward expansion and establishing American settlements in the Oregon Country. Therefore, they were eager to support to a bill that included a thorough exploration of the Pacific Northwest coastline and interior. Benton, unlike many other Democrats, was also keenly interested in overseas trade. But he also worried that Atlantic maritime trade forced the United States to defer to European powers. Instead, Benton promoted the overland settlement of the Pacific Coast as a conduit to trade with Asia. ${ }^{47}$ Both Benton and Lewis shared a vision that government land grants would encourage settlers to venture to the Far West, where they could market their surplus via the maritime trade of the Pacific Ocean. Earlier, Benton had supported the temporary preemption acts of the 1830 s, as well as the permanent "Log Cabin" bill of 1841, which gave squatters the first right to purchase western lands for cultivation. ${ }^{48}$ Benton, however, was not averse to spending federal dollars on scientific and commercial exploration. In 1842, Benton secured the passage of a bill authorizing his son-in-law, John Charles Fremont, to explore, survey and map the

\footnotetext{
${ }^{45}$ Ray Allen Billington and Martin Ridge, Westward Expansion: A History of the American Frontier (UNM Press, 2001), 208.

${ }^{46}$ Jeremiah N. Reynolds, Address on the Subject of a Surveying and Exploring Expedition to the Pacific Ocean and South Seas: Delivered in the Hall of Representatives on the Evening of April 3, 1836 (Harper \& brothers, 1836), 297.

${ }^{47}$ Henry Nash Smith, Virgin Land: The American West as Symbol and Myth, 12th Printing (Second edition) (Harvard University Press, 2007), 23.

${ }^{48}$ Hugh Prince, Wetlands of the American Midwest: A Historical Geography of Changing Attitudes (University of Chicago Press, 2008), 155.
} 
Oregon Trail as far as the South Pass of the Rocky Mountains. ${ }^{49}$ The support of such influential Democrats was necessary if the expedition was to have any chance of passing Congress.

After two years of grueling preparations, the U.S. Ex. Ex. was finally underway in August 1838 under the command of Lt. Wilkes, an expert surveyor with an avid interest in astronomy and naturalism. Unfortunately, Wilkes, who was forty years old at the time, was far less experienced as either a seaman or military leader. According to historian Constance Bordwell, “[E]ven Wilkes supporters found him arrogant, suspicious, secretive, sardonic, and unduly exacting.. ${ }^{, 50}$ His assignment also led to tensions between Wilkes and the other officers joining him on the expedition. For instance, his second-incommand, Lt. William Hudson, held slight seniority over Wilkes, and Hudson initially refused to serve under him. The U.S. Navy resolved this dilemma by removing all military trappings from the voyage and promoted the expedition as a purely civil mission. ${ }^{51}$ However, according to historian D. Graham Burnett, the mission retained much of its military purpose and character: "It had been conceived as an operation to extend the sway of American influence, and to overawe recalcitrant natives - missions that lay tacit in Wilkes's instructions to "diminish the hazards of the ocean." Furthermore, Burnett argues that Wilkes's surveying and cartographical activities

\footnotetext{
${ }^{49}$ Smith, Virgin Land, 27.

${ }^{50}$ Constance Bordwell, "Delay and Wreck of the Peacock: An Episode in the Wilkes Expedition," Oregon Historical Quarterly 92, no. 2 (July 1, 1991): 120.

${ }^{51}$ D. Graham Burnett, "Hydrographic Discipline among the Navigators: Charting an 'Empire of Commerce and Science' in the Nineteenth-Century Pacific," in The Imperial Map: Cartography and the Mastery of Empire, ed. James R. Akerman (University of Chicago Press, 2009), 201.

${ }^{52}$ Ibid., 202.
} 
incorporated the synchronized nautical maneuvers of naval warfare, making frequent use of cannons and landing craft. ${ }^{53}$

Given the concurrent rise of the nation-state, empire building, and scientific inquiry, Wilkes's assignment to survey and map of foreign territories must be seen as part of a larger colonialist project. Before lands or people can be conquered or exploited, they must first be known. While various cartographic practices have existed in many cultures since ancient times, the European powers of the eighteenth and nineteenth century seized on technological advances in mapmaking, such as the chronometer in 1761, to extend the reach of their empires beyond their own coasts. ${ }^{54}$ The increasingly accurate maps of the nineteenth century provided European and American elites knowledge with new ways to imagine their position in a shrinking world. According to historian Greg Dening, "The map-readers in bureaus and salons needed to make the globe a real world and the real world a map for the strategies of empire.",55

Cartography also embodied the uneven power dynamics necessary for imperial domination. The abstract knowledge embedded in a map can be understood as a form of what Michel Foucault called “power/knowledge.” For Foucault, geography is one of many disciplines in which acts of measurement, examination, inquiry, and surveillance are inextricably intertwined with normative judgments and deployments of force on bodies and spaces. ${ }^{56}$ The maps produced by the U.S. Ex. Ex. were made for the benefit of

\footnotetext{
${ }^{53}$ Ibid., 216.

${ }^{54}$ Benedict Anderson, Imagined Communities: Reflections on the Origin and Spread of Nationalism (Verso, 2006), 173.

55 James R. Akerman, The Imperial Map: Cartography and the Mastery of Empire (University of Chicago Press, 2009), 185.

${ }^{56}$ Michel Foucault, Power/Knowledge (New York: Pantheon Books, 1980), 63-77.
} 
the United States and its commercial and military interests, rather than the indigenous peoples who inhabited the surveyed territories. In many cases, conquered and exploited peoples are not granted access to cartographic information. This was a crucial aspect of American expansion, since surveying was the primary means to inscribe property, the essential precursor to the privatization of land previously held in common.

\section{Saules and the Black Maritime World}

Saules's was a product of both maritime America and what cultural theorist Paul Gilroy calls the Black Atlantic, a hybridic cultural formation that encompasses Africa, Europe, and the Americas, while transcending specific national and ethnic origins. ${ }^{57}$ Saules lived during a time in which, despite rampant racial prejudice, some black men could earn a living for themselves and their familes on the seafaring vessel or in a seaport town. Furthermore, those involved in overseas commerce and exploration traveled remarkable distances and experienced a variety of cultures in an era in which most Americans never ventured far from their hometowns. The fact that Saules was living on the West Coast of South America when he signed on the U.S. Ex. Ex. suggests how far the Black Atlantic extended by the late 1830 s.

What exactly Saules was doing in Callao when he joined the U.S. Ex. Ex. in 1839 remains a mystery. There is no historical evidence that supports the notion that he was Peruvian. On the other hand, there is ample data that suggests he was American. In a November 1845 letter from British spy Henry I. Warre to Peter Skene Ogden, Warre

\footnotetext{
${ }^{57}$ Paul Gilroy, The Black Atlantic: Modernity and Double Consciousness (Harvard University Press, 1993), ix.
} 
referred to Saules as an "American. ${ }^{, 58}$ More specifically, Oregon lawyer Silas B. Smith described Saules as a "Virginia negro." ${ }^{, 59}$ Regardless of his national origins, Saules was a seasoned sailor who likely came to Callao aboard a ship. In 1846, he told U.S. Navy Lieutenant Neil M. Howison that, prior to arriving in the Oregon Country in 1841, he "had followed the sea twenty years." ${ }^{, 60}$ Callao was an active seaport in the 1830 s and Saules might have arrived as part of the crew of a whaling or merchant marine ship. Another possibility is that Saules sought to profit from conflict taking place between newly independent Latin American nation-states. When the U.S. Ex. Ex. arrived in June of 1839, Chile had defeated Peru six months earlier in the War of Confederation (18361839). According to historian William Stanton, Callao was full of "drunken and unemployed" American soldiers of fortune and perhaps Saules fought among their ranks. ${ }^{61}$ At any rate, a black man like Saules would not have stood out in Callao, which was a cosmopolitan seaport typical for the maritime world. For instance, Charles Erskine, who served with the U.S. Ex. Ex. as a teenager, later wrote about a St. John's Day celebration he witnessed during their brief stay in Callao: "Several nationalities were present—Peruvians, Chileans, Indians, negroes, half-breeds, and others of both sexes." ${ }^{.62}$

\footnotetext{
${ }^{58}$ George Simpson, "Secret Mission of Warre and Vavasour," The Washington Historical Quarterly 3, no. 2 (April 1, 1912): 141.

59 Silas H. Smith, "Celebrations in Clatsop County," Cumtux: Clatsop County Historical Society Quarterly 24, no. 1 (Winter 2004): 40.

${ }^{60}$ Neil M. Howison, "Report of Lieutenant Neil M. Howison on Oregon, 1846: A Reprint," The Quarterly of the Oregon Historical Society 14, no. 1 (March 1, 1913): 5.

${ }^{61}$ Stanton, The Great United States Exploring Expedition of 1838-1842, 112.

${ }^{62}$ Charles Erskine, Twenty Years Before the Mast: With the More Thrilling Scenes and Incidents While Circumnavigating the Globe Under the Command of the Late Admiral Charles Wilkes, 1838-1842, (Lakeside/Donnelley, 2006.), 79.
} 
The cosmopolitan quality of seaports like Callao was a reflection of the multiethnic composition of most sailing ships during the period, from 1812 to 1860 , when the United States dominated maritime commerce in the South Pacific. Herman Melville captured this milieu in his 1851 novel Moby Dick. In the 1840s, Melville worked aboard a whaling ship that traveled a similar route as the U.S. Ex. Ex. and he later used Wilkes's narrative of the expedition as research material when writing his most famous novel. ${ }^{63}$ Its chapter "Midnight, Forecastle" reveals an American whaling crew that included New England, Dutch, French, Sicilian, Pacific Islander, black, Chinese, American Indian, Irish, and East Indian sailors. ${ }^{64}$ One reason for this ethnic diversity during an era of pervasive white supremacism was that it was not feasible for either American or British ships to meet the demand for maritime labor with all-white crews. The exigencies of war and the expansion of maritime commerce resulted in employment opportunities aboard whaling ships, merchant ships, naval boats, and vessels commanded by privateers and pirates. For laborers in the nineteenth century, toiling aboard a deep-sea vessel was among the most difficult, dangerous and least remunerative work available. White seamen had to surrender their freedom for the duration of a voyage and were among the most impoverished and marginalized white laborers of the nineteenth century. ${ }^{65}$ This often resulted in sailors deserting their ships when they reached a habitable seaport, one of the few forms of resistance available to maritime laborers. Moreover, frequent desertion and disciplinary problems on deep-sea voyages created job

\footnotetext{
63 Philbrick, Sea of Glory, xxiv.

${ }^{64}$ Herman Melville, Moby Dick (Toronto; New York: Bantam Books, 1981), 186-93.

${ }^{65}$ W. Jeffrey Bolster, Black Jacks: African American Seamen in the Age of Sail (Cambridge, Mass.: Harvard University Press, 1997), 70.
} 
opportunities for sailors located in various seaports. For instance, Saules joined the U.S. Ex. Ex. following the desertion of eight men during its brief stop in Callao, including ship's cook Elias Russel, whom Saules likely replaced. ${ }^{66}$ This was not an unusual number for an expedition that ultimately lost over a half of its original crew of 346 to desertion, death and dismissal. ${ }^{67}$

This demand for labor made black sailors like Saules ubiquitous in the age of sail. While many whites rejected maritime work, for African American freemen in the North and South, as well as enslaved black men, the sea afforded some of the best opportunities for economic compensation and independence in a deeply racist society. In the antebellum North, black men suffered discrimination in most trades and had difficulty procuring productive land. ${ }^{68}$ According to historian Jeffery Bolster, "African American men found considerable maneuvering room in maritime society." ${ }^{69}$ While all sailors' pay was typically low, black sailors working on ships, particularly those working out of northern ports often earned the same amount as whites with the same job title. ${ }^{70}$ Free black men, such as Saules, or foreign black nationals, were able to enlist in the U.S Navy and receive the same wages, privileges, and opportunities for promotion as white sailors. ${ }^{71}$ Naval ships, both British and American, also provided better food and easier work than whaling or merchant ships and some positions offered healthcare and

\footnotetext{
${ }^{66}$ Wilkes, Narrative of the United States Exploring Expedition, 1850, xxxiii-lvi.

${ }^{67}$ Philbrick, Sea of Glory, 293.

${ }^{68}$ Bolster, Black Jacks, 158.

69 Ibid., 75.

${ }^{70}$ Ibid., 161.

${ }^{71}$ Barbara Tomblin, Bluejackets and Contrabands: African Americans and the Union Navy (University Press of Kentucky, 2009), 17.
} 
pensions. ${ }^{72}$ For Saules, the opportunity to work on a U.S. Navy vessel was probably too good to pass up.

It is difficult to obtain an accurate percentage of how many black men serve on board ships, since most crew lists made no specific mention of race or ethnicity. However, many lists had categories for complexion and hair. Historian Martha S. Putney delved into nineteenth century crew lists and sought out terms such as "African," “colored," "black," "wooly," and "negro," to determine the presence of black crewmembers sailing out of various American cities. ${ }^{73}$ She found that the percentage of black sailors was lowest in the South and highest in the North. For example, in 1838, 8.4 percent of crews sailing from New Orleans were identifiably black, although that is a conservative estimate. $^{74}$ In 1836 , the percentage of black crewmembers working out of Providence, Rhode Island was 30 percent. $^{75}$ The percentages were nearly as high in New York City, Boston, and New Bedford.

According to Bolster, black sailors were crucial to the development of a coherent black community in antebellum America: "Maritime wages provided crucial support for black families and underwrote organizations such as churches and benevolent societies through which black America established an institutional presence and a voice." ${ }^{, 76}$ Sailing ships were the connective tissue between the far-flung ports of the Atlantic and Pacific Oceans and the plantations of the American South, West Indies, and South America. As

\footnotetext{
${ }^{72}$ Bolster, Black Jacks, 31.

${ }^{73}$ Martha S. Putney, Black Sailors: Afro-American Merchant Seamen and Whalemen Prior to the Civil War, Contributions in Afro-American and African Studies no. 103 (New York: Greenwood Press, 1987), 2.

74 Ibid., 120.

75 Bolster, Black Jacks, 235.

${ }^{76}$ Ibid., 4.
} 
such, they formed essential lines of communication for the black diaspora, much of which was highly subversive. Bolster also argues that maritime work, particularly the rigorous tasks associated with whaling, afforded black men the opportunity to assert their masculinity and equality with whites, in contrast with more demeaning work they often performed on land. ${ }^{77}$ For Bolster, "Racial boundaries certainly existed, but they were often secondary to those established by the institution of the ship.",78

While social class, knowledge, and ability may have trumped race aboard many ships during the age of sail, black sailors still struggled with a rigid social order that was often racially encoded. Many white sailors disliked blacks and even extremely skilled and experienced black sailors had virtually no chance of ascending to the officers' class. Less skilled black sailors often served as ordinary seamen--called "boys," as opposed to skilled sailors known as "men"--and suffered a disproportionate amount of hazing. ${ }^{79}$ And while a majority of black sailors did not work as cooks or stewards, these jobs were almost exclusively filled by blacks. These were also positions that existed outside the ranking system of officers, men, and boys and were often gendered feminine by other sailors who placed a premium on masculinity. ${ }^{80}$

Yet black men like Saules had much to gain by taking such positions. By the 1830s, a heightened demand for maritime labor meant that black cooks and stewards frequently earned as much or more than white sailors. ${ }^{81}$ This also resulted in an

\footnotetext{
${ }^{77}$ Ibid., 176.

${ }^{78}$ Ibid., 75.

${ }^{79}$ Ibid., 77.

${ }^{80}$ Ibid., 168-169.

${ }^{81}$ Ibid., 168.
} 
improvement of their image. For instance, in his 1875 profile of Saules for the Overland Monthly, Charles Melville Scammon referred to Saules as having held "the important position of cook aboard the Peacock." ${ }^{, 82}$ And serving as a cook or steward did not mean that one was not a capable seaman. For example, Saules, who worked for two years as a cook for the expedition, later commanded a schooner on the Columbia River, at that time one of the most dangerous rivers in North America. Cooks like Saules could also enjoy a sense of independence while working in their kitchens, even if they were often isolated from the rest of the crew.

In addition to serving as a cook, Saules was a fiddler who also likely worked as a musician on the U.S. Ex. Ex., although "musician" was not an official capacity noted on the crew list. According to Silas B. Smith, Saules and his fiddle were later fixtures at social events in Clatsop County in the late $1840 \mathrm{~s}^{83}$ The journal of Lt. Reynolds, an officer with the U.S. Ex. Ex., reveals that there was a fiddler aboard the Peacock, the ship on which Saules served. On January 23, 1840, when the Peacock's anchor first struck land in Antarctica, an unnamed fiddler played for the elated crew as they coiled the mudcoated sounding line. ${ }^{84}$ In addition to fiddlers, naval ships and privateers frequently hired drummers, trumpeters, french horn players and fife players. On sailing ships, music was used not only to entertain, but also to recruit unemployed sailors in seaports, call men to their posts, and provide rhythmic accompaniment for drills and tedious collective labor. Music also had a diplomatic function. For example, when the expedition reached the Fiji

\footnotetext{
82 Scammon, "Pioneer Nig Saul," 275.

83 Smith, "Celebrations in Clatsop County," 40.

${ }^{84}$ Stanton, The Great United States Exploring Expedition of 1838-1842, 162.
} 
Islands, Charles Erskine, one of the few non-officers to write about the U.S. Ex. Ex. recalled an event in which unidentified crew members of the Peacock "treated the natives to a regular, old-fashioned negro entertainment. ${ }^{.85}$ This does not necessarily mean that the performers were black, as minstrel shows featuring white performers in blackface were already popular by the 1830 s, but as Erksine does not mention the race of the performers, it is possible that Saules was involved.

While not every maritime musician was black, it was a stereotypical role for black sailors. In 1808, a naval surgeon wrote, "There will be no difficulty procuring a 'fiddler,' especially among the coloured men, in every American frigate, who can play most of the common dancing tunes. ${ }^{.86}$ Black sailors also left their mark on the kind of music performed on ships. This included not only the African American-derived music of minstrel shows, then the most widely known music in the United States, but also the most famous musical form to emerge during the age of sail, the sea shantey. The shantey is an example of the "chanter-response performance" form common to African and African American musical forms. ${ }^{87}$ According to Bolster, "The shantey's late-eighteenth-century origins corresponded with rising numbers of black sailors, and the period of the shantey's greatest development after 1820 was one of black prominence at sea. ${ }^{\Perp 88}$

Music was only one example of what made ships and seaports such important sites of cultural transmission. Paul Gilroy refers to a ship as "a living, micro-cultural,

\footnotetext{
${ }^{85}$ Erskine, Twenty Years Before the Mast, 190.

${ }^{86}$ Bolster, Black Jacks, 34.

${ }^{87}$ Ibid., 217.

${ }^{88}$ Ibid.
} 
micro-political system in motion. ${ }^{, 89}$ Maritime exploration and commerce created countless middle grounds on both land and sea; these were sites where diverse peoples encountered and interacted with each other, forging new hybridic cultural practices and meanings. ${ }^{90}$ Maritime labor brought sailors from varied backgrounds together. The mutual needs of sailors and the absence of a strict racial hierarchy bridged cultural gaps and helped forge a more egalitarian social order than what was found in the cities of the northeastern and southern United States. According to Bolster, "Sailors constantly crossed cultural and geographic boundaries as they maneuvered between white and black societies ashore and maritime society afloat." ${ }^{91}$ Sailors of various races wore similar fashions such as baggy trousers and earrings, and had similar images tattooed on their skin. ${ }^{92}$ Because black sailors, who were often multilingual and deeply cosmopolitan, were such a large presence on ships and in seaports, their impact on maritime culture was considerable. For instance, black and white seafarers also shared in the oral tradition of “yarning," a practice likely influenced by African folk traditions. ${ }^{93}$ And because maritime culture did not exist in a vacuum and had a reciprocal relationship with culture on the mainland, black sailors were a major factor in the development of an American culture inseparable from African American cultural forms and practices.

According to those either who knew or wrote about him, Saules fit the profile of the worldly, versatile, and independent black sailor. He was capable of maneuvering

${ }^{89}$ Gilroy, The Black Atlantic, 4.

${ }^{90}$ White, The Middle Ground, X.

${ }^{91}$ Bolster, Black Jacks, 35.

92 Ibid., 93.

93 Ibid., 42. 
between various communities and cultures, while employing various means of survival. According to early Oregon settler Silas B. Smith, "From his associations with cultured people [Saules] had acquired considerable knowledge of things in general and could sustain a very interesting conversation on a variety of subjects." ${ }^{94}$ Another early settler, Samuel T. McKean, met Saules in Linnton, Oregon aboard the schooner he commanded. Saules struck him as "an odd character who felt the dignity of this position as captain of so fine a craft." 95 Writer and naturalist Charles Melville Scammon noted Saules' “shrewdness" and "aptness for picking up a language."96 Scammon also mentioned Saules' gift for storytelling, or "yarning," in either English or Chinook Jargon. ${ }^{97}$ Saules apparently also developed a reputation for hard living. According to American settler John Minto, who met Saules in Astoria in 1844, “...I do not believe [fellow Astoria resident] Indian Cooper carried one tenth the vice about with him than J.D. Sauls [sic] did. ${ }^{, 98}$

\section{Saules Joins the U.S. Ex. Ex.}

Saules served with the U.S. Ex. Ex. for slightly over two years, from July 1839 to sometime in the late summer/early fall of 1841. Prior to Saules signing on, the expedition had already visited Madeira, the Cape Verde Islands, Rio de Janeiro, Cape Horn, and the South Shetland Islands near the still-undiscovered Antarctic Peninsula. Immediately after

\footnotetext{
${ }_{95}^{94}$ Smith, "Celebrations in Clatsop County," 40.

95 Samuel T. McKean, "Memoirs of Samuel T. McKean,” Cumtux: Clatsop County Historical Society Quarterly 13, no. 1 (Winter 1992): 6-7.

${ }_{96}$ Scammon, "Pioneer Nig Saul," 273.

${ }^{97}$ Ibid.

98 Jean Brownell, Negroes in Oregon Before the Civil War, (Oregon Historical Society, Unpublished Manuscript),30.
} 
disembarking from Callao, the expedition surveyed and collected specimens in the South Pacific for the purpose of making charts to help American whalemen find crucial provisions. Their destinations included the Tuamotu Archipelago, Tahiti, and Samoa. In December, the expedition again ventured south, engaged in an imperial competition with Great Britain and France to be the first nation to reach the rumored continent at the South Pole. On January 16, 1840, midshipman Henry Eld and Lt. William Reynolds of the Peacock, Saules's ship, spotted the mountains of the Antarctica. Unfortunately, this detail was not captured in the ship's official log and the crew of Wilkes's flagship, the U.S.S. Vincennes, claimed discovery of the continent on January 19, 1840. This was after Wilkes surveyed 1500 miles of Antarctic coastline, later known as Wilkes Land. This oversight complicated the United States' claim, since a competing French exploring expedition also recorded landfall on the continent the same day.

On February 21, 1840, the Peacock ended its ice exploration and sailed to Sydney, Australia for extensive repairs. The British founded Sydney as a convicts' colony in 1788. Prior to that, it was home to the Eora aboriginal people, most of whom had perished by the early nineteenth century due to the diseases brought by the British. By the time the expedition arrived, Sydney was a notoriously rowdy seaport that exhibited the heterogeneity of maritime culture. According to crewmember Charles Erskine, "Here you find all nations mixed up together, eating, drinking, singing, dancing, gambling, quarreling, and fighting." 99 Erskine, a young Bostonian, was particularly struck by what he perceived as a disregard for racial norms in Sydney: "It was a curious,

${ }^{99}$ Erskine, Twenty Years Before the Mast, 116. 
but not an uncommon sight, to see a big, burly, thick-lipped negro, black as a coal, walking on the street, arm in arm, with a beautiful English lady, both neatly dressed." Like Callao, this was not a place where Saules would have stood out.

On May 1,1840, the Peacock rejoined the other ships of the U.S. Ex. Ex. for an extensive survey of the Fiji Islands. Europeans first reached the Fiji Islands in 1789, although surveyors had only charted a small portion of its hundreds of islands. While the Fiji Islands had a reputation among European and American sailors for endemic warfare and cannibalism, the verdant islands had long held appeal for potential deserters, many of whom abandoned their ships to live among the indigenous inhabitants. However, due to earlier and presumably negative interactions, many islanders took a dim view of colonial interlopers. For example, Wilkes expressed astonishment upon meeting a group of Fiji children who ran away from him in terror, suggesting that previous contact with sailors was far from benign. ${ }^{101}$

Despite claims that the expedition's goals were peaceful, at this point in the mission it was obvious that Wilkes intended to inform Fiji's indigenous population that they must now acquiesce to U.S. power. For instance, the navy assigned Wilkes to investigate the alleged 1834 murder of ten American sailors by a Fiji headman named Veidovi. On May 20, 1840, Wilkes dispatched the Peacock to Rewa, where the crew was instructed to apprehend the chief. On May 21, Lt. William L. Hudson of the Peacock, took Veidovi's brother, the current king of Rewa, hostage aboard the ship as ransom for the delivery of Veidovi. Saules was almost certainly present when this occured, as

\footnotetext{
100 Ibid., 117.

101 Philbrick, Sea of Glory, 196.
} 
Reynolds' references a ceremony in which a drum roll was accompanied by “several abortive squeaks of the fife breathed by the Ship's Cook." On May 22, Veidovi was captured and told by Lt. Reynolds that he would be brought to the United States where he would "become a better man... with the Knowledge, that to kill a white person was the very worst thing a Feegee man could do." ${ }^{, 102}$ While the officers promised Veidovi that he could eventually return to Rewa, he died in New York City in 1842, mere hours after the expedition reached its final destination.

Such heavy-handed treatment of Fiji Islanders only increased in brutality over the next three months. By mid July, a surveying crew in Solevu Bay had one of their boats claimed by local inhabitants when it washed ashore during a gale. Wilkes ordered his flagship, the Vincennes, to return to the bay and retrieve the boat by force if necessary. When the village headman returned the boat, Wilkes realized the villagers had kept the surveyors' personal belongings. On July 14, Wilkes vowed to "make an example of these natives" and ordered his men to burn the village of Tye to the ground. ${ }^{103}$ Luckily for the villagers, they had already abandoned the village to the safety of nearby hills.

Less than two weeks later, the expedition ran dangerously low on provisions and a small surveying crew went ashore the island of Malolo to bargain with Native people for food. When negotiations broke down, a melee ensued that resulted in the death of two officers, including Wilkes's nephew. In retaliation, Wilkes sent seventy men to the southern tip of Malolo where they were instructed to kill as many warriors as possible and raze their villages. In the end, two villages were completely destroyed and eighty

\footnotetext{
102 Ibid., 202.

103 Ibid., 211.
} 
Native people were killed. When a handful of survivors presented Wilkes with a peace offering, he refused, insisting that all survivors must appear before him, bring all the food they could muster, and recognize that the United States was "a great Nation, a powerful people." ${ }^{104}$ According to Wilkes, if he had not ordered this act, the Malalo islanders would "never acknowledge themselves conquered."105 While Saules's ship, the Peacock, was not involved in the massacre, Wilkes ordered the crew of the Peacock to bring him Veidovi, the Rewan prisoner taken two months earlier. An enraged Wilkes put Veidovi in solitary confinement and had his head shaved. This was a particularly brutal act, since Rewan headmen took immense pride in their impressive locks.

The survey of Fiji ended in August 1840, although the U.S. Ex. Ex. continued to combine the gathering of scientific knowledge with more punitive activities. In late September, the expedition reached the Hawaiian Islands and dropped anchor near Honolulu, yet another of the Pacific Ocean's boisterous multiethnic seaports. The expedition's crew then enjoyed two weeks of rest while Wilkes led a scientific mission to the summit of Mauna Loa. By this point, Wilkes believed it was too late in the year to begin surveying the Pacific Northwest and abruptly added another year to the expedition. Several crewmembers responded to this news by deserting. Wilkes also assigned the Peacock, on which Saules still served, to both survey the Gilbert, Marshall, and Caroline island groups and punish specific Native persons for past offenses. Their first order of business was to visit the Samoan village of Saluafata and capture two recalcitrant tribal chiefs wanted in connection with the murder of an American seaman fifteen months

\footnotetext{
104 Stanton, The Great United States Exploring Expedition of 1838-1842, 211.

105 Philbrick, Sea of Glory, 229.
} 
earlier. ${ }^{106}$ In April, the Peacock arrived at Utiroa in the Drummond Islands when another massacre of Native people by the crew occurred. Apparently, the Peacock's commander, Lt. Hudson, and some crewmembers went ashore to have dalliances with several Native women when they realized they had been lured into a trap. The crewmembers returned to the ship with the exception of crewmember John Anderson, whom was presumed dead. In retaliation, the Peacock sent 87 men ashore who destroyed the village and killed approximately twenty Native people. ${ }^{107}$ When Lt. Reynolds, now the commander of the expedition vessel the U.S.S Flying Fish, heard of the latest massacre, he wrote, "It seems to me, that our path through the Pacific is to be marked in blood." ${ }^{108}$ The Peacock returned to Oahu on June 14 with its provisions depleted and prepared for the voyage to the Oregon Country.

The survey of the Pacific Northwest was intended as the crowing achievement of the U.S. Ex. Ex. Although the sponsors of the expedition were interested in projecting U.S. power throughout the world, the United States had yet to develop any serious designs on territories in the South Pacific. The case was different with the Oregon Country. Wilkes understood that his survey was a prelude to U.S. claims and wrote that he was "fully satisfied [Oregon] was to be full part and parcel of our country." 109 The region, which encompassed all of present-day Oregon, Washington, Idaho, and British Columbia, was still under joint occupation by the United States and Great Britain, a delicate arrangement first established by the Convention of 1818 and extended in 1827.

\footnotetext{
106 Stanton, The Great United States Exploring Expedition of 1838-1842, 237-39.

107 Ibid., 244.

108 Philbrick, Sea of Glory, 267.

109 Herman Joseph Viola and Carolyn Margolis, Magnificent Voyagers: The U.S. Exploring Expedition, 1838-1842 (Smithsonian, 1985), 221.
} 
Many in the United States believed that Robert Gray's 1792 discovery of the Columbia River, as well as the Lewis and Clark Expedition, granted them sole rights to the territory below the $49^{\text {th }}$ parallel, the site of the current border between the United States and Canada. The British, on the other hand, had a far more pronounced presence in the region due to the activities of the Hudson's Bay Company (HBC), a joint stock company chartered by the English crown to extract valuable furs from North America. In 1824, the HBC, which had been active in the Oregon Country since 1812 and established a major base of operation at Fort Vancouver near the confluence of the Columbia and Willamette Rivers. Eleven years earlier, during the War of 1812, British fur traders strong-armed the representatives of John Astor, an American fur magnate, into selling them his Pacific Fur Company, based near present-day Astoria, Oregon. ${ }^{110}$ This act cemented Britain's domination of the fur trade in the region for nearly thirty years. And although by 1841 the fur trade was in decline, Fort Vancouver's chief factor John McLoughlin had diversified its operations to export timber, grain, and various foodstuffs to other outposts and settlements throughout the Pacific Slope.

Lt. Wilkes and his flagship, the Vincenne, arrived at Cape Disappointment, near the mouth of the Columbia on April 28, 1841. Wilkes originally sought to cross the Columbia bar and continue up the river. However, upon arrival, he found conditions too treacherous. Wilkes later wrote, "Mere description can give little idea of the terrors of the bar of the Columbia: all who have seen it have spoken of the wildness of the scene..."

\footnotetext{
${ }^{110}$ Carlos Arnaldo Schwantes, The Pacific Northwest: An Interpretive History, Revised (University of Nebraska Press, 2000), 64.

${ }^{111}$ Charles Wilkes, Narrative of the United States Exploring Expedition: During the Years 1838, 1839, 1840, 1841, 1842, Volume Four (Lea and Blanchard, 1845), 293.
} 
The Columbia bar remains one the most perilous river entrances in the world and the only one in the United States in which vessels are required to use a bar pilot. ${ }^{112}$ Wilkes opted not to cross the bar and instead sailed north to begin his survey of the Puget Sound, which he found far more to his liking: "Nothing can exceed the beauty of these waters, and their safety." ${ }^{113}$ While Wilkes found the region's Nisqually Indians "vicious and exceedingly lazy, $" 114$ he treaded far more lightly among the indigenous peoples of the Pacific Northwest than those of the South Pacific. He even forbade his crew from purchasing the valuable pelts offered by local Native people. One reason for this was that Wilkes did not want to alarm the region's major players in the fur trade, such as those located at nearby at the HBC's Fort Nisqually. Wilkes believed that if they detected his imperial designs, they would be less willing to provide shelter and provisions for his crew. Once Wilkes completed the first part of his reconnaissance, he led an overland expedition back to the mouth of the Columbia to rendezvous with the Peacock and begin the survey of the Columbia River. On May 23, when Wilkes reached the Columbia, he discovered that the Peacock had still not arrived. After spending some time at Fort Vancouver, where John McLoughlin hosted him with typical hospitality, Wilkes headed up the Willamette River.

During Wilkes's overland exploration of the lower Columbia and Willamette Valley, he witnessed three distinct, if not exactly discrete, forms of colonialism in the region. The first was the economic colonialism practiced by the British-backed HBC. For the British government, joint stock companies were a cost-effective means of establishing

\footnotetext{
112 Philbrick, Sea of Glory, 264.

113 Wilkes, Narrative of the United States Exploring Expedition, 1845, 305.

114 Ibid., 417.
} 
colonies, since investors were the sole source of funding. Such companies often functioned as de facto governments in foreign territories and were not bound by any higher authority. Theoretically, this meant that the governor and council of a company could enslave or annihilate indigenous inhabitants with impunity. ${ }^{115}$ In reality, according to Richard White, the most common tactic employed by such colonizers was to forge economic dependence among indigenous peoples. He claims economic colonialism was characterized by "the attempt, not always successful or consistent, by whites to bring Indian resources, land, and labor into the market." 116 In exchange, Native people received items they could not necessarily produce for themselves, such as firearms, ammunition, imported foodstuffs, and clothing.

However, it is a mistake to conclude that the HBC was the dominant power in the region. Because the employees of Fort Vancouver never amounted to more than a few hundred people, the profitability of the fur trade in Pacific Northwest was entirely contingent on obtaining the cooperation and labor of local Native groups, who, despite the devastation of imported diseases, still outnumbered Euro-Americans in the region. For example, the Chinook-speaking peoples had controlled trade on the Lower Columbia since long before contact with Europeans, due to their geographic position between coastal Native groups and those living on the Columbia Plateau. Therefore, the cooperation of Native people could not be attainted through violent coercion. And although McLoughlin had held a monopoly on firearms in the region and was known to

\footnotetext{
115 Robert V. Hine, The American West: An Interpretive History, First Printing (Little Brown \& Company, 1973), 28.

${ }^{116}$ Richard White, The Roots of Dependency: Subsistence, Environment, and Social Change Among the Choctaws, Pawnees, and Navajos (U of Nebraska Press, 1988), xv.
} 
launch brutal punitive expeditions against local Native people who undermined the fur trade, Fort Vancouver had no army or police force. Indeed, when Wilkes visited Fort Vancouver, he observed that the two large cannons on display were strictly ornamental. ${ }^{117}$ But McLoughlin and the HBC were never met with tremendous resistance, since many local Native groups were active and interested participants in the fur trade. This meant that the HBC could forge alliances with powerful Native groups through intermarriage or other forms of mutually beneficial collaborations. This is a prime example of a middle ground, place in which accommodation trumped coercion or isolation and new social and cultural relations were formed. In such a middle ground, according to Richard White, "Whites needed Indians as allies, as partners in exchange, as sexual partners, as friendly neighbors.",118

The British and their surrogates among the $\mathrm{HBC}$ were also more interested in using the Pacific Northwest as an extraction colony than establishing a permanent British settlement, which would have necessitated the importation of families as opposed to male laborers. Instead, McLoughlin oversaw a heterogeneous and cosmopolitan culture at Fort Vancouver, a place not unlike the various seaports visited by the U.S. Ex. Ex. Residents included Britons, French-Canadians, and American citizens, as well as the Native or mixed-race wives of managers and employees. Other employees and laborers, including Pacific Islanders, black men, and Iroquois from the East Coast, lived in a village of log huts located immediately outside the fort. When Wilkes toured this village, he noticed the

\footnotetext{
${ }^{117}$ Stanton, The Great United States Exploring Expedition of 1838-1842, 255.

${ }^{118}$ White, The Middle Ground, xxvi.
} 
preponderance of mixed-race children "of all shades of colour, from the pure Indian to that of the white." 119

Another form of colonialism encountered by Wilkes during his exploration of the Pacific Northwest was religious colonialism. After returning from Fort Nisqually in late May, Wilkes visited the Methodist mission near the present site of Salem, Oregon. In 1834, the Reverend Jason Lee, a Canadian Methodist missionary, traveled overland to the region, inspired by the journey of four Indian men--three Nez Perces and one Flathead-who traveled from the Columbia Plateau to St. Louis and asked Superintendent of Indian Affairs William Clark for the "book." This event galvanized the religious community in the Northeast and was commonly perceived as an invitation to send missionaries to the Pacific Northwest to convert Native people to Christianity. ${ }^{120}$ Lee sought to convert the Native population to Christianity and establish a permanent colony in which whites and Native people would live in civilized harmony. When he arrived, Lee was greeted warmly by McLoughlin, who recommended that he establish his mission in the fertile Willamette Valley instead of the more rugged and remote environs of the Columbia Plateau. Lee listened and chose a site for his mission in close proximity to French Prairie, a community of retired fur trappers and their mixed-race families, even though the local population of Kalapuyan Indians had been severely reduced by an earlier outbreak of malaria. Lee had hoped to convert Native people to Christianity through a combination of religious instruction and agricultural training. However, Lee and the missionaries were continually frustrated by the fluid and syncretic spiritual practices of a heterogeneous

\footnotetext{
119 Wilkes, Narrative of the United States Exploring Expedition, Volume Four, 1845, 332.

${ }^{120}$ For more information on the Flathead Delegation, see Albert Furtwangler, Bringing Indians to the Book (Seattle: University of Washington Press, 2005).
} 
Native population. By 1836, Lee lamented, "The truth is we have no evidence that we have been instrumental in the conversion of one soul."121 By 1841, Lee and the Methodists had largely abandoned their initial conversion project and focused almost exclusively on agriculture, tilling two hundred acres of farmland and raising herds of livestock. As such, the Methodists posed a serious challenge to HBC hegemony. When Wilkes arrived at the Methodist Mission that same year, he was struck by the scarcity of Indians and furious that the mission had neglected their initial project while still collecting large sums of money from their backers on the East Coast. ${ }^{122}$ Three years later, the Mission Society withdrew their support.

Prior to visiting the Methodist mission, Wilkes traveled near Willamette Falls, where he encountered a small group of American settler colonists with little interest in furs or converting Indians. Many of these settlers arrived overland rather than via ships. Among the earliest American settlers in the Oregon Country was Hall Jackson Kelly, a passionate supporter of an American settlement in Oregon. Kelly came to the Willamette Valley in 1834, accompanied by Ewing Young, an American cattleman. Kelly soon fell ill and returned to his native Boston, while Young remained in the area. Young soon became one of the richest men in the region by breaking Fort Vancouver's cattle monopoly. Wilkes's meeting with the settlers took place mere months after Young's death in February 1841, which sparked a crisis over how best to divide his estate in a region without any coherent system of law. Present was George Gay, Young's business partner and traveling companion on an 1837 cattle drive, whom Wilkes described as "as

${ }^{121}$ Cornelius J Brosnan, Jason Lee, Prophet of the New Oregon (Rutland, VT: Academy Books, 1985), 78.

122 Edmond S. Meany, "Diary of Wilkes in the Northwest," The Washington Historical Quarterly 16, no. 1 (January 1, 1925): 51 . 
much Indian as a white can be." ${ }^{\prime 23}$ The group also included Robert Moore, an original member of the Peoria Party, who later presided as justice of the peace in the case that led to Saules's expulsion from the Willamette Valley. ${ }^{124}$ In 1840 , a nine-man overland party led by Thomas Jefferson Farnham arrived in Oregon from Peoria, Illinois, inspired by Rev. Lee's national speaking tour, in which the missionary extolled the agricultural virtues of the region. According to Wilkes, these "idle people" were "all agog about laws \& legislatures, with governors, judges, \& minor offices all in embryo." ${ }^{2125}$ They were also frustrated by McLoughlin's power and their economic dependence on Fort Vancouver; they hoped the arrival of the U.S. Ex. Ex. signaled the end of British control in the region. Wilkes warned them that establishing their own government too soon would only antagonize the $\mathrm{HBC}$; he advised them to wait "until the government of the United States should throw its mantle over them.",126

\section{The Wreck of the Peacock}

The Peacock, with Saules aboard, finally reached the mouth of the Columbia River on July 18, 1841. Like Wilkes before him, the Peacock's Lt. Hudson found the conditions at the bar unfavorable. Unfortunately, Hudson, reluctant to fall further behind schedule, decided to brave the high breakers of the bar. However, he soon had second thoughts and tried to steer the ship back to more tranquil waters. This act was futile, as the ship's keel had hit bottom and its bow was permanently submerged in sand of what

\footnotetext{
123 Bordwell, "Delay and Wreck of the Peacock," 145.

124 Wilkes, Narrative of the United States Exploring Expedition, Volume Four, 1845, 347.

125 Meany, "Diary of Wilkes in the Northwest," 46.

${ }^{126}$ Wilkes, Narrative of the United States Exploring Expedition, Volume Four, 1845, 353.
} 
would later become known as Peacock Spit. The high waves at the bar meant that the Peacock's crew was trapped aboard the ship until river conditions subsided, even though the ship was filling with water. By evening, a crowd of onlookers formed, most of whom were local Chinook Indians, who watched as the waves began to break the ship apart. Luckily for the crew of the Peacock, John Dean, a black steward from the Vincennes was among the onlookers. Although the Vincennes had sailed north weeks earlier, Dean was asked to remain at the Columbia to watch for the arrival of the Peacock. Dean organized a rescue party comprised of Chinooks--including two highly skilled bar pilots--who rowed out to the beleaguered ship the following morning and began bringing the crew to shore. Once the high waves subsided, Hudson ordered the release of the Peacock's own boats and eventually all 133 crewmembers were safely off the ship. Hudson never mentioned his black and Chinookan rescuers, or their racial identity, in his official report of the wreck. ${ }^{127}$ Through this omission, Hudson boosted his own role in the rescue and downplayed the nautical expertise of local Native people.

Following the wreck of the Peacock, its crew showed little motivation to participate in the ongoing survey of the Columbia. They were likely traumatized by their watery ordeal, although some blamed Lt. Hudson's lack of skill and experience in performing surveys. ${ }^{128}$ Regardless, except for the forty men Wilkes sent to Fort Vancouver to help harvest crops, most of the crew remained idle for the next several weeks. During this time they established a makeshift village at Fort George, near presentday Astoria, dubbed "Peacockville" by the crew. It consisted of crude huts made from

\footnotetext{
127 Philbrick, Sea of Glory, 272.

128 Stanton, The Great United States Exploring Expedition of 1838-1842, 253.
} 
pine branches and old planks and soon boasted street signs, gambling dens, a bowling alley, a barbershop, and a bakery. ${ }^{129}$ In 1841 , Fort George was a modest trading post operated by HBC official, James Birnie, who generously offered provisions to the Peacock's crew. Chinook and Clatsop Indians also visited the crew to sell them fresh venison and salmon, as well as to gamble. ${ }^{130}$

The remaining months of the U.S. Ex. Ex. were comparatively uneventful. On August 10, 1841, Lt. Wilkes interrupted the idyllic scene at Fort George by negotiating the purchase of a brig from John McLoughlin, the Thomas H. Perkins, to replace the Peacock. On October 15, the brig, rechristened the Oregon, joined the rest of the expedition on the voyage south to Mexican California and the tiny seaport of San Francisco. While Wilkes wrote that California "was not calculated to produce a favorable impression either of its beauty or fertility," he was extremely impressed by the size and safety of San Francisco's harbor. ${ }^{131}$ Wilkes believed this harbor, combined with Puget Sound, made the Pacific Coast "admirably situated to become a powerful maritime nation, with two of the finest ports in the world." ${ }^{132}$ The expedition then again traveled west to the Hawaiian Islands, the Philippines, Singapore, and South Africa. On early June 10, 1842, the surviving ships of the U.S. Ex. Ex. finally arrived in New York City.

The immediate outcome of the U.S. Ex. Ex. was not what its backers or Wilkes anticipated. While Wilkes's charts would remain in use by mariners well into the twentieth century, and the expedition's specimens would form the basis for the

\footnotetext{
129 Ibid., 253.

130 Ibid., 253.

131 Charles Wilkes, Voyage Round the World: Embracing the Principal Events of the Narrative of the United States Exploring Expedition (G.P. Putnam, 1851), 574.

${ }^{132}$ Wilkes, Narrative of the United States Exploring Expedition, Vol. 5, 1845, 151.
} 
Smithsonian Institution, the expedition was initially mired in controversy. For instance, upon his return to the United States, Wilkes and several of his officers received courtsmartial. Wilkes himself was charged with mistreating his subordinate officers, losing the Peacock at the Columbia bar, and illegally flogging sailors and marines. Although, he was cleared of all but the flogging charge, his reputation was tarnished. A staunch Democrat, Wilkes discovered to his dismay that John Tyler's new Whig administration now occupied the White House. Not only did President Tyler want to distance himself from previous Democratic administrations, his secretary of state, Daniel Webster, was involved in precarious negotiations with Great Britain regarding a potential border agreement for the Oregon Country. Tyler did not want to tip his hand regarding the importance of Oregon to the interests of the United States and, therefore, issued a news blackout regarding the expedition's exploits. ${ }^{133}$ Even former political allies turned against the U.S. Ex. Ex. Senator Thomas Hart Benton, perhaps the most prominent supporter of claiming and settling the Oregon Country, later became frustrated that Wilkes's survey of the mouth of the Columbia River did not conform to his own vision as the ideal site for a seaport. He later came to view the U.S. Ex. Ex. as a rival venture to his son-in-law John C. Fremont's overland expeditions to the Far West. In 1846, Benton published a pamphlet in which he attacked the expedition and its scientific findings. ${ }^{134}$

\section{Saules Remains in the Oregon Country}

${ }^{133}$ Philbrick, Sea of Glory, 304.
${ }^{134}$ Ibid., 341. 
Saules never joined the Oregon on its journey to California and its not known exactly when or why Saules deserted the U.S. Ex. Ex. While some historians, such as Russell Dark, have cited Saules's desertion as proof of his status as a "troublemaker," there was nothing unusual about desertions during the U.S. Ex. Ex. ${ }^{135}$ According to Wilkes's official report, there were 125 total desertions over the course of the expedition. ${ }^{136}$ Saules was one of three sailors who deserted at Fort George, which was a lower number than usual, since most desertions occurred at established seaports like Rio de Janeiro, Callao, Honolulu, and Sydney. One possible explanation for why Saules deserted when he did was that two years spent on a grueling maritime voyage was enough, especially one that culminated in a catastrophic shipwreck. Given the conditions aboard deep-sea vessels, it is surprising he lasted that long. According to Jeffrey Bolster, "Sailors were debilitated by vitamin-deficient food, blazing sun, and wet accommodations; threatened by their own ship's equipment and the sea's perils; and answerable to tyrannical captains backed by harsh admiralty laws."137 This might also explain why Saules, who had made his living on the sea for twenty years, never participated in another deep-sea mission.

Another reason could be that Saules never intended to continue on to New York City. In the antebellum United States, a black man like Saules still faced harsh racial discrimination and scant job prospects in the free northern states. The southern slave states were even more perilous for a free black man. Many white southerners reviled free

\footnotetext{
135 Russell Dark, Bar Sinister: The Story of the Columbia River Bar Pilots (Clatsop County Historical Society: Unpublished manuscript), 6.

${ }^{136}$ Wilkes, Narrative of the United States Exploring Expedition, 1850, xxxiii-lvi.

${ }^{137}$ Bolster, Black Jacks, 29.
} 
black sailors for flaunting racial conventions and it was not unheard of for southern authorities to arrest black men and sell them into slavery. ${ }^{138}$

Or perhaps Saules simply weighed his options and decided that the Pacific Northwest was an ideal place to settle. In the first half of the nineteenth century it was not uncommon for black sailors to desert their ships on the Pacific Coast and start new lives in a region in which racial caste systems were not yet ossified. This region also boasted several legends of shipwrecked black sailors who joined coastal Native communities. ${ }^{139}$ Interestingly enough, the other two sailors who deserted in Oregon were also black. They were Henry Evans, an officer's cook, and Warren Johnson, an officer's steward. Unfortunately, neither has left a discernable trace in the historical record. Desertions of this kind were especially common in California, where a black man could become a Mexican citizen. For example, Allen Light was a black sailor who jumped ship at Santa Barbara, acquired Mexican citizenship, and later became the first U.S. born black man to serve as a Mexican official. ${ }^{140}$ While such lofty positions were unavailable to black men in the Oregon Country in 1841, the HBC had no strict racial hiring policy. And since there was no formal government in the region, there were no racist laws.

Lt. Hudson, the commanding officer of the Peacock, had another plausible explanation for why Saules, Evans, and Johnson deserted: he believed they had fallen in love with local Indian women. Hudson also decided not to pursue the men once the

\footnotetext{
138 Ibid., 213.

139 Gordon B. Dodds, Oregon: A History (W. W. Norton \& Company, 1977), 1836.

140 Quintard Taylor, In Search of the Racial Frontier: African Americans in the American West, 1528-1990 (W. W. Norton \& Company, 1999), 48.
} 
Oregon was prepared to disembark for California. ${ }^{141}$ Charles Melville Scammon supported this theory in his 1875 profile of Saules, although the piece often reads as a caricature, due to Scammon's overstated prose and indulgence in ethnic stereotypes: "[O]n the day of sailing of the brig Thomas H. Perkins, Saul was missing from among his shipmates. Scarcely, however, had the ship cleared the land before he made his appearance, accompanied by an Indian bride, decked out in all the geegaw glories of her tribe. ${ }^{1142}$ Scammon claimed that Saules quickly learned the Chinook jargon, the trade language of the lower Columbia River area, and gained his vast knowledge of the river and its tributaries from his time spent among the Chinookan people.

Apparently Saules did not live exclusively among the Indians. According to Scammon, he "led a half-civilized, half-savage life for the first few years after coming on shore; sometimes living with the Indians, at other times with the Whites." ${ }^{143}$ In her 1964 profile of Saules for the Seattle Times, historian Lucile McDonald referred to Saules as "Cape Disappointment's first settler." 144 It does appear that Saules built a cabin facing Baker Bay at Cape Disappointment soon after deserting. According to John E. Pickernell, an early Euro-American settler in what is now Pacific County, Saules lived near the present location of Fort Canby and in 1842 was Pickernell's only English-speaking neighbor. ${ }^{145}$ This location was also less than two miles from the Chinook village at the site of the present-day town of Ilwaco.

\footnotetext{
${ }^{141}$ Bordwell, "Delay and Wreck of the Peacock," 178.

142 Scammon, "Pioneer Nig Saul," 273.

143 Ibid.

144 Lucile McDonald, "Cape Disappointment's First Settler," 4.

${ }^{145}$ Herbert Hunt and Floyd C. Kaylor, Washington, West of the Cascades: Historical and Descriptive; the Explorers, the Indians, the Pioneers, the Modern (S. J. Clarke publishing Company, 1917), 436.
} 
The identity of Saules's wife is unknown. One questionable source, a 1901 article in the Pacific Monthly suggests he was married to a Chinookan woman whose sister was married to John McClure, an early Astoria settler who arrived in 1843. The article refers to McClure's brother-in-law as "a colored man, who lived at or near the cape, as a pilot." The article clearly references a later incident involving Saules and the U.S.S. Shark, but it confuses the Shark for the Peacock and misidentifies the Shark's commander as Wilkes. Furthermore, the article refers to the "colored man" in question as George Washington. There was a black sailor named George Washington who worked at Fort Vancouver as a cook and pilot in the 1830s. In 1840, Washington served as a pilot aboard the Lausanne, a ship carrying the Methodist missionaries Daniel Lee and Joseph E. Frost, but ran the ship aground. ${ }^{146}$ However, there is no evidence Washington ever lived on Cape Disappointment. Instead, he moved to the Willamette Valley in 1839 and, according to the 1850 census, was still living there with his wife, a Quinault woman. ${ }^{147}$

One year after he deserted, Saules established a boat service between Astoria and Cathlamet. ${ }^{148}$ Approximately thirty miles from Astoria, Cathlamet was once the largest Indian village on the lower Columbia and in 1842 was still home to between three and

\footnotetext{
${ }^{146}$ Daniel Lee, and Joseph H. Frost, 10 Years in Oregon (Glen Adams, 1968), 224.

147 Bruce McIntyre Watson, "Lives Lived West of the Divide: A Biographical Dictionary of Fur Traders Working West of the Rockies, 1793-1858," 989, accessed September 29, 2013, http://www.lulu.com/shop/bruce-mcintyre-watson/lives-lived-west-of-the-divide-a-biographical-dictionaryof-fur-traders-working-west-of-the-rockies-1793-1858/ebook/product20951764.html;jsessionid=A6B2B4ABA128846DBE5D81F1E3BBD496.

${ }^{148}$ E. W. Wright, Lewis \& Dryden's Marine History of the Pacific Northwest: An Illustrated Review of the Growth and Development of the Maritime Industry, from the Advent of the Earliest Navigators to the Present Time, with Sketches and Portraits of a Number of Well Known Marine Men (Lewis \& Dryden Printing Company, 1895), 21.
} 
four hundred Cathlamet, Wahkiakum, Chinook, and Cowlitz people. ${ }^{149}$ This made Saules an important part of the region's trade network, which transported goods and resources between Indian communities and HBC outposts. His craft was a small fore-and-aft schooner in which he carried passengers, livestock and miscellaneous freight. Traveling between these locations was not an easy task in 1842, as the Columbia had no channel improvements, dams, or levees. Therefore, Saules must have been a skilled and knowledgeable navigator. According to author E.W. Wright, "[Saules] continued in this trade for a considerable length of time and made money." 150 This was four years before James Birnie, the HBC employee who helped the crew of the Peacock at Fort George, moved his family from Fort George and established a trading post at Cathlamet.

Saules seemed to adapt to life in the Oregon Country very quickly. The region, like the ships and seaports of maritime world, offered him ample room to maneuver, both physically and socially. All were examples of middle grounds, described by Richard White as places "in between cultures, peoples, and in between empires and the nonstate world of villages." ${ }^{\prime 51}$ In the following year, however, Saules would test the region's flexibility. He and his young family, which at this point included both wife and children, would leave their home at Cape Disappointment and relocate in the Willamette Valley. During this same period, hundreds of Anglo-Protestant settlers also arrived in the region. Collectively, they would bring a very different vision for the Oregon Country, one that provided little space for Saules and his family. They would also dramatically change the

\footnotetext{
149 Thomas Nelson Strong, Cathlamet on the Columbia: Recollections of the Indian People and Short Stories of Early Pioneer Days in the Valley of the Lower Columbia River (The Holly Press, 1906), 10.

${ }^{150}$ Wright, Lewis \& Dryden's Marine History of the Pacific Northwest, 21.

${ }^{151}$ White, The Middle Ground, x.
} 
balance of power in the region, a balance that previously accounted for a surprising amount of social and cultural fluidity. 


\section{Chapter Two: The Settler Invasion and the Banishment of Saules}

In the early 1840 s, James D. Saules moved from the mouth of the Columbia River to Oregon's verdant Willamette Valley. The immense agricultural potential of the area likely drew Saules and he probably saw it as a place where he could support his family by working the soil. But Saules was not alone. Many other Americans made the same calculation at roughly the same time. Unlike Saules, most were white settlers from the Old Northwest or the so-called Border States who had probably never set foot aboard a deep-sea vessel. Instead, they loaded up their wagons with whatever possessions they deemed necessary and traveled several thousand miles along the Oregon Trail. Their sheer numbers altered the delicate balance of power that had existed between indigenous peoples and Euro-Americans in the Pacific Northwest. The overland settlers also brought a distinct ideology that had a dramatic effect on regional laws, notions of property rights, and race relations. This chapter will explore how Saules and others dealt with this settler invasion. At various times, Saules either cooperated with these new arrivals or resisted them. Yet the ultimate outcome for Saules, as well as many previous inhabitants of the region, was displacement.

Sometime before the end of 1843, Saules and his wife and children relocated to an area six miles south of Oregon City in the Willamette Valley. Formerly known as Willamette Falls, Oregon City was originally the site of an HBC sawmill and later a Methodist mission. Oregon City is less than thirty miles from the confluence of the Columbia and Willamette rivers and ideally situated for transporting goods and produce throughout the region. Saules purchased a farm and horse from a settler (and apparent 
friend) named Winslow Anderson (also known as George Winslow). It is not known why Saules left Cape Disappointment. Perhaps he decided to change his occupation from sailor to farmer. Or he may have viewed the growing settlement at Willamette Falls as an opportune place to expand his freight business, especially as the decline of the fur trade in the early 1840 s probably lowered demand for his services. Saules also may have obtained additional work at the Methodist Mission, which apparently hired non-white laborers.

Winslow Anderson, the man from whom Saules bought the horse and farm, was a Bostonian who first arrived in the Oregon Country from California in $1834 .^{152} \mathrm{He}$ was a member of the same party that included Hall Jackson Kelly and Ewing Young. Early Oregon historian William Gray referred to Anderson as "colored,"153 while Methodist missionary Elijah White, who first came to the region in 1837 , identified him as "mulatto." ${ }^{154}$ He initially settled in French Prairie, married a Native woman, started a family, and eventually moved north to a farm on Clackamas Plains. In 1838, he and his family traveled with Methodist missionary Henry Perkins to Wascopam near the Dalles, where he spent a year helping Perkins build his mission. ${ }^{155}$ Anderson apparently made an impression on Perkins's wife, Elmira, who wrote, “Our hired man, an American by birth, but not all White blood, appears to be deeply anxious about his spiritual welfare, and I

\footnotetext{
152 Robert Boyd and Robert Thomas Boyd, People of The Dalles: The Indians of Wascopam Mission (Universtiy of Nebraska Press, 2004), 235.

${ }^{153}$ William Henry Gray, A History of Oregon, 1792-1849: Drawn from Personal Observation and Authentic Information (Harris \& Holman, 1870), 191.

${ }^{154}$ Elijah White, Ten Years in Oregon: Travels and Adventures of Dr. E. White and Lady, West of the Rocky Mountains; with Incidents of Two Sea Voyages via Sandwich Islands around Cape Horn, Containing, Also, a Brief History of the Missions and Settlement of the Country ... Description of the Soil, Production and Climate (Press of Andrus, Guantlett, \& Co., 1850), 232.

${ }^{155}$ Boyd and Boyd, People of The Dalles, 309.
} 
hope we shall soon see him rejoicing in God." ${ }^{, 156}$ Anderson apparently also worked as a physician until the 1840 arrival of HBC surgeon Dr. Forbes Barclay, who drew away his patients. $^{157}$

\section{The Great Migration of 1843}

In October of 1843, around the time Saules and his family were settling into life on their new farm, an event took place that drastically altered the social, cultural, political, and ethnic landscape of the Pacific Northwest. A group of between 700 and 1000 men, women, and children, known as the Great Migration of 1843, arrived in the Willamette Valley from Independence, Missouri via the overland Oregon Trail. ${ }^{158}$ Yet the Great Migration was not an isolated occurrence; it was an early and dramatic product of a deeper imperialist project that would come to be known as Manifest Destiny.

Furthermore, the Great Migration was not a state sponsored mission; it was primarily conceived and organized by the settlers themselves. Furthermore, many of the EuroAmericans who had previously come to live and work in the Pacific Northwest, and perhaps Saules himself, are better classified as migrants than colonists and did not necessarily intend to remain permanently. This was not the case with those who joined the Great Migration, many of whom shared a vision of permanent Anglo-American

\footnotetext{
156 Ibid.

${ }^{157}$ Hubert Howe Bancroft and Frances Fuller Victor, History of Oregon, Volume One (The History Company, 1886), 77.

158 In American and black history, the term "Great Migration" is more commonly used to describe the mass movement of African Americans from the South to Northern industrial cities during the early to midtwentieth century. For an example of the term used in the context of the Oregon Trail, see William G. Robbins, Landscapes of Promise: The Oregon Story, 1800-1940 (University of Washington Press, 1999), 72 .
} 
settlement in a region that was not officially part of the United States. Or as historian Patrick Wolfe argues, "The colonizers come to stay--invasion is a structure not an event."159 About a third of the new American immigrants settled near Saules's new residence in Oregon City. The town itself grew from one building in 1840 to 75 structures by the end of $1843 .^{160}$ Those overlanders who did not settle in Oregon City fanned throughout the Willamette Valley.

The sudden Americanization of the Willamette Valley resulted in a huge shift in both demographics and the economic base of the region. Two years earlier, in 1841, Lt. Charles Wilkes estimated that there were between 700 and 800 people, mostly male, classified as "white, Canadians, and half breeds" in the Oregon Country, However, only 150 of these were Americans; the rest were connected with the fur trade and the HBC. ${ }^{161}$ And although he estimated that there were 19,204 Natives in the entire Oregon Country, indigenous people living closest to Euro-American settlements had seen their numbers reduced dramatically by exogenous diseases. For example, Wilkes estimated that in 1841 there were fewer than 2000 Native people living in the Lower Columbia and Willamette Valley regions combined. ${ }^{162}$ The new American immigrants were mostly AngloProtestant farm families who brought, in addition to their various belongings, cattle, sheep, and pigs, as well as seeds to grow various crops. Their plan was to create a selfcontained agrarian settlement with little use for the region's indigenous population.

\footnotetext{
${ }^{159}$ Patrick Wolfe, Settler Colonialism (Continuum, 1998), 2.

${ }^{160}$ William G. Robbins, Oregon: This Storied Land (Oregon Historical Society Press, 2005), 44.

161 Charles Wilkes, "Report on the Territory of Oregon," The Quarterly of the Oregon Historical Society 12, no. 3 (September 1, 1911): 291.

162 Ibid.
} 
This marked a shift from previous Euro-American inhabitants of the Pacific Northwest, namely fur industry workers and missionaries, whose project, at least initially, involved intimate contact and involvement with Native people. Two major aspects of this involvement were sexual relationships and marriages between Euro-American men and Native or mixed-race women. Such intimate contact not only provided comfort and companionship, but also was part of the alliance-building process of fur trade society. Saules, too, apparently developed marital bonds with local Native people very soon after arriving in Oregon. On the other hand, the married male immigrants of the Great Migration brought their wives with them, making interracial relationships unnecessary for the reproduction of the community. Single male settlers also avoided interracial marriages, which resulted in low marrying ages among young Anglo-American girls and various efforts to import white women to the region. Such changes in demographics and economics meant that the era of accommodation and interdependency between Native people and Euro-Americans would soon be over. Unlike immigrants such as Saules and those associated with the fur industry, the overlanders sought to remake the existing social order in their own image rather than adapt to it.

Settler colonialism involves an outside group attempting to permanently transform and claim sovereignty over a region by displacing or disposing of its previous inhabitants. While in Oregon, this current would eventually engulf Saules, indigenous peoples were the primary concern for the American immigrants. Many of the overland settlers who arrived in the 1840 s assumed that Natives were a vanishing race, conveniently clearing the way for white settlers. This mentality allowed Peter Burnett, the 
Missouri lawyer-politician who was instrumental in organizing the Great Migration, to write of conquest as a fait accompli: "[W] came, not to establish trade with the Indians, but to take and settle the country exclusively for ourselves... They instinctively saw annihilation before them." ${ }^{\prime 63}$ Although colonialism is defined by external domination and uneven power dynamics, settler colonialism is quite distinct from other forms. Historian Lorenzo Veracini describes this difference in simple terms: "If I come and say 'you, work for me', it's not the same as saying 'you, go away." "164 If economic colonialists like the HBC saw Native people as a valuable source of labor, and religious colonialists like the Methodists initially saw them as subjects requiring redemption, the settler colonists sought their eventual erasure. This could be accomplished through various historically tested means, including relocation, assimilation, and even extermination.

Veracini also contends that settler colonists often ironically legitimated their sovereignty claims by positing their own de facto indigeneity, thus transforming actual indigenous peoples into outsiders. ${ }^{165}$ This is consistent with American expansionist ideology in the mid-nineteenth century, in which claims for settler indigeneity were usually predicated on geographical inevitability, since no ocean separated the Oregon Country from the United States. This continentalism was evident in columnist John L. O'Sullivan's famous 1845 pronouncement of the United States' "manifest destiny to overspread the continent allotted by Providence for the free development of our yearly

\footnotetext{
${ }^{163}$ Peter Hardeman Burnett, Recollections and Opinions of an Old Pioneer (D. Appleton, 1880), 150.

164 Lorenzo Veracini, “Introducing," Settler Colonial Studies 1, no. 1 (2011): 3.

${ }^{165}$ Lorenzo Veracini, Settler Colonialism: A Theoretical Overview (Palgrave Macmillan, 2010), 18.
} 
multiplying millions."166 Senator Thomas Hart Benton of Missouri, perhaps the nation’s foremost proponent of expansion, insisted that American ownership of the continent was so natural and preordained that it was intuitively understood by all: "The heart of the Indian sickens when he hears the crowing of the cock, the barking of the dog, the sound of the axe, and the crack of the rifle. These are the true evidences of the dominion of the white man; these are the proofs that the owner has come and means to stay, and then the Indians feel it to be time for them to go." Benton's use of the term "white man" is crucial, as it demonstrates the prevalent notion in antebellum America that only whites could be considered American. Because of this, a black man like Saules, who was almost certainly born in the United States, was unable to establish his own indigeneity anywhere on the continent.

The Great Migration was unprecedented in scope. Overland journeys were still relatively rare in the early 1840 s and the previous wagon train that arrived in 1842 , the largest up to that point, consisted only of about one hundred people. The vast majority of non-Natives in the Oregon Country, like Saules, had arrived on ships. Most previous overland American migrations were incremental, with settlers traveling much shorter distances from established communities. Most of the overlanders who arrived in Oregon in 1843 came from the states that comprised the Old Northwest (Iowa, Illinois, Indiana, and Ohio), as well as the so-called "border states" between the North and South (Kentucky, Tennessee, and Missouri). ${ }^{167}$ Although the aforementioned Peter Burnett was

\footnotetext{
166 John O’Sullivan, “Annexation,” United States Magazine and Democratic Review 17, no. 1 (August 1845): 5-10.

${ }^{167}$ Quintard Taylor, "Slaves and Free Men: Blacks in the Oregon Country, 1840-1860," Oregon Historical Quarterly 83, no. 2 (July 1, 1982): 153-154.
} 
instrumental in organizing the wagon train, its cohesion was not based on top-down authority. According to historian John Mack Faragher, "The train divided, ostensibly into two administrative units but actually into a long meandering line of march in which the real solidarities were among kinship and neighborhood groupings."168 This emphasis on kinship is an essential component of settler colonialism and differentiates the Great Migration from earlier overland emigrations, which were comprised mostly of male travelers. Such relations likely helped sustain the travelers as they endured an arduous six-month journey, traveling nearly 2,000 miles to start over in a region most had only read about.

It is difficult to generalize about a group as large as the Great Migration, but historians have identified several key reasons why they embarked on such a difficult journey. Classical republicanism and the Jeffersonian ideal of an "Empire of Liberty," a vision of a United States populated by Anglo-Protestant self-sufficient yeoman farmers, were still very influential in the 1840 s. Its proponents imagined a self-sufficient society free from the evils of wage labor, industrialization, northeastern financiers and southern slavery. The theory also implied that an ethnically homogenous, agriculturally based society would be free from class and racial distinctions. But these settlers were not anachronistic throwbacks to an earlier age; historian William Robbins argues that "they carried with them the core values and conflicts associated with a modernizing, capitalist world." ${ }^{169}$ According to historian David Alan Johnson, the Willamette Valley "drew settlers who sought a 'middle landscape,' a rural place somewhere between the isolated

\footnotetext{
168 John Mack Faragher, Women and Men on the Overland Trail (New Haven: Yale University Press, 2001), 31.

${ }^{169}$ Robbins, Oregon, 45.
} 
and self-sufficient household order of yeoman myth and a world of commercialized agriculture dependent on uncertain markets." ${ }^{170}$ Many hoped the Pacific Northwest would grant settlers access to coveted foreign markets in the Far East that could absorb their agricultural surplus. This was especially relevant since the nation was still wracked by an economic depression brought on by the Panic of 1837 and several years of flooding had damaged farmland in the Old Northwest. ${ }^{171}$ Geographer William Bowen claims that better health was the primary motivation for moving west, as various diseases, particularly cholera, were prevalent in the Mississippi Valley in the 1830 s. ${ }^{172}$ Finally, during this period, disputes over religion and slavery erupted in violence in various American towns and cities, likely increasing the appeal of westward migration.

The published letters and articles written by missionaries in Christian newspapers, combined with Reverend Jason Lee's regular trips to the East to encourage support for his mission, led to a word of mouth campaign that eventually erupted into a phenomenon called "Oregon Fever."173 Soon emigrant guidebooks provided those afflicted with information regarding Oregon's agricultural potential and Native population. Potential settlers carefully perused articles, letters and guidebooks before deciding to embark on their journey to the West. The texts published by the mission family were most influential in promoting white settlement, assuring settlers that Natives would soon be extinct. In 1844, missionaries Daniel Lee and John Frost wrote the following in regards to Natives in the Willamette Valley: "These Indians are the most degraded human beings that we

\footnotetext{
${ }^{170}$ David Alan Johnson, Founding the Far West: California, Oregon, and Nevada, 1840-1890 (University of California Press, 1992), 8.

${ }^{171}$ Robbins, Oregon, 43.

${ }^{172}$ Ibid.

${ }^{173}$ Whaley, Oregon and the Collapse of Illahee, 148.
} 
have met in all our journeying... and the time is not far distant when the last deathwail will proclaim their universal extermination."174 These writings suggest how little remained of Rev. Jason Lee's original vision of whites and Christianized Natives sharing Oregon's future.

Although the Great Migration was not a state-sanctioned event, some key American politicians laid the groundwork and offered passionate support for the venture. The two Democratic senators from Missouri, Thomas Hart Benton and Lewis Linn, were particularly forceful in their expansionist rhetoric and legislative actions; both were frustrated that the U.S. government had done little to promote American settlement in Oregon. Many future overlanders were also heartened by Linn's 1841 Oregon Territorial Bill, which would have granted 640 acres of Oregon land to every white male willing to cultivate it. According to historian Elliott West, "Linn was following a familiar strategy of westward boosterism: get settlers on the ground, and the government will find a way to follow." 175 This notion, however, was still controversial in the early 1840 s and the bill failed to pass in the House of Representatives in 1843. Whig President John Tyler also vehemently opposed it, insisting that land titles could not be granted before the United States reached a permanent territorial agreement with Great Britain. ${ }^{176}$ Still, the terms of Linn's bill would be echoed in subsequent successful legislation.

Racialism, the notion that race determines inherent traits or abilities, was a significant characteristic of expansionist ideology. It was also likely the main reason why

\footnotetext{
${ }^{174} \mathrm{H}$, Lee, and Frost, 10 Years in Oregon, 104-5.

175 Elliott West, The Last Indian War: The Nez Perce Story, 1st ed. (Oxford University Press, USA, 2011), 47.

176 Tom Chaffin, Pathfinder: John Charles Frémont and the Course of American Empire (Macmillan, 2004), 147.
} 
the American immigrants denied Saules and most non-whites a place in settler society. The settlers' interpretation of Jefferson's "Empire of Liberty" was essentially racialist, as it was predicated on yeoman farmers being white freemen. Jefferson himself held explicitly racialist views: "I advance it, therefore, as a suspicion only, that the blacks, whether originally a distinct race, or made distinct by time and circumstance, are inferior to the whites in the endowment both of body and mind." ${ }^{177}$ Jefferson was not alone among the nation's founders, as the 1790 Naturalization Act reserved American citizenship for white males only. And although many republicans living outside of the Deep South were opposed to slavery, most were also opposed to civil rights for freed slaves and believed blacks could not be incorporated into white society. ${ }^{178}$ And while Jefferson initially thought Indians could assimilate into American society through interbreeding and by adopting sedentary agriculture, by the Jacksonian Age, white settlers encroaching on Indian lands in the Southeast and Old Northwest held mostly contempt for Native peoples. ${ }^{179}$ Racialism was also bolstered in the 1830 s by the postenlightenment advent of race "science." Many writers and intellectuals of the period offered pseudo-scientific theories as proof of white supremacy. ${ }^{180}$

For many prominent American proponents of westward expansion, the future of the white race seemed more important than the future of the nation. For example, in an 1846 speech before Congress, Senator Benton employed racialist, rather than nationalist, terminology to promote the settlement of the Pacific coast by whites: "I know of no

\footnotetext{
${ }^{177}$ Thomas Jefferson, Notes on the State of Virginia (J.W. Randolph, 1853), 55.

${ }^{178}$ Reginald Horsman, Race and Manifest Destiny: The Origins of American Racial Anglo-Saxonism (Harvard University Press, 1981), 102.

${ }^{179}$ Ibid., 10.

${ }^{180}$ Horsman, Race and Manifest Destiny, 43-61.
} 
human event which promises a greater, past or to come, which promises a more beneficent change upon earth than the arrival of the van of the Caucasian race (the CelticAnglo-Saxon division) upon the border of the sea which washes the shore of eastern Asia." ${ }^{181}$ He went on to delineate a racial hierarchy, insisting that the Caucasian and "Mongolian" races were "far above the Ethiopian, or Black—above the Malay, or Brown... and above the American Indian, or Red." ${ }^{\prime 12}$ Yet Benton was also among those who conceived of race in binary terms. During the Second Seminole Wars, in which Florida Seminole warriors fought alongside black allies against the U.S. Army, Benton claimed, "[I]t is his own white race which has been the sufferer in Florida; and that the colored races have exulted in the slaughter and destruction of [those] descended...from the white branch of the human race." ${ }^{183}$ Many settlers would later view Saules and other black people in Oregon as having an innate and potentially dangerous affinity with indigenous people, presumably based on skin tone.

\section{The Provisional Government and Elijah White's Laws for Native People}

American settlers enshrined their notions of sovereignty and racial homogenization in the Pacific Northwest, as well as identified territorial insiders and outsiders, through the creation and enforcement of various legal mechanisms. While American settlers had been forming small governmental institutions as early as 1839 , the most transformative was the establishment of a provisional government on May 2, 1843,

\footnotetext{
${ }^{181}$ Senator Benton, 29th Cong., 1st Sess,, Congressional Globe (May 28, 1846), 917.

182 Ibid., 917-918.

${ }^{183}$ Horsman, Race and Manifest Destiny, 205.
} 
six months before the arrival of the Great Migration. ${ }^{184}$ Lansford Hastings, an attorney who led the 1842 wagon train to Oregon, urged the formation of a government to "take into the consideration the propriety for taking measures for civil and military protection of this colony." 185 This was the body that established a framework for expropriating Native land. While the 102 Euro-Americans who voted on whether or not to create the provisional government included several French-Canadians opposed to the idea, the Americans narrowly won. The settlers initially created a relatively weak government with a three-person executive committee instead of a governor and strove to establish a middle ground between establishing independence from the United States or obvious alignment with it. Even so, HBC Chief Factor John McLoughlin, as well most settlers associated with the fur trade who did not want the region incorporated into the United States, correctly identified the nascent government as a bold move in that direction. ${ }^{186}$ American settlers insisted the government was necessary to protect their land claims. And while the Oregon Country would not officially become part of the United States until the boundary question was settled in 1846, the influence of U.S. policy on the provisional government was undeniable. For example, its laws were based on the territorial statues of Iowa and heavily influenced by American republicanism. ${ }^{187}$

Private ownership of land was a central facet of American republicanism and the provisional government's chief function was to legitimate land claims. According to William Robbins, the immigrants "were largely landseekers, looking to establish

\footnotetext{
184 Robert J. Loewenberg, "Creating a Provisional Government in Oregon: A Revision," The Pacific Northwest Quarterly 68, no. 1 (January 1, 1977): 18.

185 Schwantes, The Pacific Northwest, 114.

186 Ibid., 114.

187 Ibid.
} 
community structures that would provide security for their landed property and a degree of economic opportunity for later arrivals." ${ }^{\prime 188}$ Prior to the provisional government, land in the Oregon Country, whether held by the HBC, retired fur trappers, Methodist missionaries, or American settlers, was held through simple preemption and use. ${ }^{189}$ Winslow Anderson, the man from whom Saules bought his farm, would have established his property in this manner and their transaction probably occurred outside the purview of any legal body. According to Peter H. Burnett, who became a member of the legislative branch of the provisional government shortly after arriving in the region in the fall of 1843, this was an unacceptable situation: "Our commercial and business transactions were considerable. Difficulties were daily occurring between individuals in relation to their "claims'."190 The Organic Code of 1843 restricted land claims to 640 acres and restricted settlers from holding more than one claim at a time. ${ }^{191}$ Yet these terms were actually far more generous than existing U.S laws pertaining to the public domain. As such, the Organic Code was one of the main factors that inspired over 10,000 midwesterners to emigrate between 1844 and 1849, thus further hastening the Americanization of the region. ${ }^{192}$

The provisional government also limited citizenship to "every free male descendant of a white man who has resided in the territory for 6 months," which resulted in a racialized definition of citizenship that disenfranchised many residents, such as

\footnotetext{
188 Robbins, Oregon, 45.

189 Robbins, Landscapes of Promise, 82.

190 Shannon Applegate, Talking on Paper: An Anthology of Oregon Letters and Diaries (Oregon State University Press, 1994), 19.

191 Ibid.

192 Johnson, Founding the Far West) 42.
} 
Saules and Winslow Anderson, who had lived in the region long before the overlanders arrived. ${ }^{193}$. This raises the question of whether a non-citizen like Saules could even have his land claim recognized by the government. The inclusion of mixed-race male offspring with white fathers was a concession to prominent settlers who had married Native women On the other hand, the government denied citizenship to the several thousand Natives who still outnumbered Euro-American settlers in the region. The citizenship rule also signaled to non-whites that an Americanized Oregon would be a white Oregon.

The provisional government also failed to protect the traditional lands of indigenous peoples. The official position of the provisional government toward Nativeowned land was the same as U.S. federal Indian policy circa 1843; it promised not to seize Native lands without permission or remuneration. ${ }^{194}$ However, in practice, the provisional government disregarded any notion of "Indian Country" and honored land claims that obviously pre-empted Native land. In 1845, the government created a provisional land office to record claims and sales. Because the land office lacked the scientific knowledge and equipment to formally survey the land, they often used Native villages and resource sites to mark their claims. ${ }^{195}$ In addition, many white settlers completely ignored Native land claims, likely assuming that Indian removal and disease would clear the way for the inevitable white settlement of the Oregon Country.

At roughly the same time American settlers were providing new rules and regulations for the Euro-American settlers in the Willamette Valley, Dr. Elijah White was

\footnotetext{
193 Robbins, Oregon: This Storied Land, 46.

194 Gray H. Whaley, Oregon and the Collapse of Illahee: U.S. Empire and the Transformation of an Indigenous World, 1792-1859 (University of North Carolina Press, 2010), 161.

195 Ibid.
} 
doing the same for the various Native groups throughout the vast region. This added to the existing pressures Euro-American settlers placed on Native people through encroachment, depletion of resources, and disease. Such pressures also occasionally resulted in violent exchanges, which later affect Saules. White was a medical doctor from New York who had first come to the Oregon Country via ship in 1837 to work with Jason Lee at the Methodist Mission. In 1841, after a falling out with Lee, White returned to the East Coast. Yet in September of 1842, he returned as part of the same wagon train that brought Hastings. Upon his arrival in the Willamette Valley, he announced to settlers that the U.S. War Department had assigned him as subagent to the Natives of the region. While this appointment made him the sole representative of the U.S. government in the region, his purported authority was tempered by the fact that the Pacific Northwest was not officially part of the United States. Furthermore, since the Oregon Country was a neutral territory, the U.S. War Department was forbidden from establishing a military presence. $^{196}$

Yet White's rules were a response to genuine fears among American settlers that Natives would not respect their property rights and might even attack their settlements. White was most concerned about the Native groups living on the Columbia Plateau, such as the Nez Perces, Cayuses, and Walla Wallas, who were still relatively strong, as they had been less affected by exogenous diseases than the Natives of the Willamette Valley. Many Natives were also justifiably convinced that the newly arrived settlers would

${ }^{196}$ West, The Last Indian War, 29. 
appropriate their lands. ${ }^{197}$ On November 15, 1842, White traveled to the Columbia Plateau with six armed men and two interpreters to meet with Nez Perce leaders and issue his new laws to them. According to Elliott West, "His goal was to convince them to accept basic rules meant to provide some stability, protect whites already there and those to come, and generally encourage settlement and development." 198 In May of 1843, upon settler rumors that the Cayuses were planning to attack the nascent community in the Willamette Valley, White held another council with the Cayuses and Nez Perces at Waiilatpu, site of Marcus and Narcissa Whitman's Presbyterian mission, in which he reiterated the importance of following his laws. ${ }^{199}$ White left feeling satisfied that he had averted a catastrophe.

While the Native groups of the Pacific Northwest had always observed laws, moral codes and systems of governance, White's laws dealt with property and violent crimes in ways alien to most Natives. For instance, article two stipulated, "Whoever burns a dwelling-house shall be hung. ${ }^{, 200}$ Hanging was a practice unknown to Natives. A more typical punishment for such a crime was retaliation in kind or payment to the victim. Furthermore, the proscription on burning structures is likely an attempt to curb the Native practice of clearing areas through burning. This was an essential feature of Native agriculture and subsistence, but it was also an activity that would likely threaten the hundreds of new buildings that would spring up over the next few years. White's laws also made it a crime to enter homes without knocking or to peer through windows,

\footnotetext{
${ }^{197}$ Bancroft and Victor, History of Oregon, Volume One, 274.

${ }^{198}$ West, The Last Indian War, 29.

${ }^{199}$ Bancroft and Victor, History of Oregon, Volume One, 276-280.

200 "Laws of the Nez Perces." Gray, A History of Oregon, 1792-1849, 228.
} 
neither of which were considered by most Natives to be improper conduct. White also wanted tribes to appoint head chiefs to control behavior, punish non-conformists, and impose order over large populations, which ran counter to traditional practices.

According to historians Robert H. Ruby and John A. Brown, "White and his successors were laying the foundation for intratribal jealousy and strife in Indian dealing with white men."201 An example of this was an incident in November of 1843 in which a Wasco Native from The Dalles named Cockstock allegedly broke every window in White's house. Cockstock was apparently retaliating for a relative flogged for unlawfully entering the Wascopam home of Methodist missionary Henry Perkins the previous June. ${ }^{202}$

\section{The Cockstock Affair}

In the early months of 1844 , Saules was directly involved in a series of events that erupted in a full-scale riot between the aforementioned Cockstock, his five Molalla traveling companions, and several white settlers in Oregon City. The incident, known as the Cockstock Affair, was a result of rising anxieties and ethnic tensions in the region, largely brought on by the imposition of foreign laws on Natives. The Cockstock Affair was particularly noteworthy since relations between American immigrants and the region's various indigenous groups had been mostly peaceful up to that point. The response of the American settlers in the aftermath of the Cockstock Affair also demonstrated how much relations had changed between Euro-American settlers and the

\footnotetext{
${ }^{201}$ Robert H. Ruby and John A. Brown, Indians of the Pacific Northwest: A History (University of Oklahoma Press, 1988), 96.

${ }^{202}$ Gray, A History of Oregon, 1792-1849, 252.
} 
region's indigenous people, especially once the settlers began to dismantle the middle ground that existed between them.

In late 1843 and early 1844, tensions between the new arrivals and the previous inhabitants, as well as continued pressures placed on the indigenous population likely made the Willamette Valley feel like a very dangerous place. Furthermore, many overlanders were disappointed that the lofty promises of Oregon boosters had yet to materialize. According to Frances Fuller Victor, the author of Hubert Howe Bancroft's 1886 History of Oregon, "They found themselves more than two thousand miles from the land of their birth, without houses to shelter them, destitute of the means of faming, without provisions or clothing, surrounded by unfriendly natives, and without the protection of their government." ${ }^{, 203}$ The following dispatch from the Willamette Valley appeared in the December 14, 1843 edition of the Missouri Republican. It captures the ominous mood that gripped the region: "The Indians on the Columbia are expected to be troublesome to these newcomers. It is supposed they are induced to acts of violence by some persons as yet unknown." The article also suggested that the HBC was preparing to use Natives to attack American settlers: "We have always believed that the Indians, backed and incited as they will be by agents and emissaries of the Hudson's Bay Co., and furnished as they doubtless will be, with arms and means of warfare from some source, would oppose the emigrants in making their settlements." This last statement appears to be pure paranoia, as the HBC's John McLoughlin, by all accounts, treated American settlers with undue kindness and generosity, since he saw them as potential customers.

${ }^{203}$ Hubert Howe Bancroft and Frances Fuller Victor, History of Oregon, Volume One, 264. 
The article closes by explicitly reminding settlers of their imperialist mission: "That the country must be conquered before it is attained, we hardly entertain a doubt...,"204

According to the official report of Indian Subagent Elijah White, sometime in 1843, Cockstock allegedly came to Saules's farm and demanded he relinquish his horse to him. Although Cockstock's Wasco people lived near the Dalles, he was related to the Clackamas people of the Willamette Valley through marriage. Saules's neighbor Anderson had hired Cockstock earlier in the year to clear the land claim he later sold to Saules. It is also possible that Anderson became acquainted with Cockstock during his stint at the Wascopam Mission. In fact, Cockstock continued performing various tasks on the farm even after it was sold to Saules. Apparently, Anderson had promised to compensate Cockstock with the same horse he later sold to Saules. On this particular visit to the farm, Cockstock seized the horse and for the next several months continued to harass both Saules and Anderson. On February 16, 1844, an alarmed Saules wrote a letter to White, demanding that he subdue Cockstock. The letter, which was later presented in White's 1844 report to the U.S. Senate, is the only known document written by Saules and is therefore included in its entirety:

SIR: I beg leave to inform you that there is an Indian about this place, of the name of 'Cockstock,' who is in the habit of making continual threats against the settlers in this neighborhood, and who had also murdered several Indians lately. He has conducted himself lately in so outrageous a manner, that $\mathrm{Mr}$. Winslow Anderson has considered himself in personal danger, and on that account has left his place, and come to reside at the falls of the Wallamette; and were I in circumstances that I could possibly remove from my place, I would certainly remove also, but am so situated that it is not possible for me to do so. I beg, therefore, that you, sir, will take into consideration the propriety of ridding the country of a villain, against the depredations of whom none can be safe, as it is impossible to guard against the lurking attacks of the midnight murderer. I have

204 “Documents,” Oregon Historical Quarterly, 4, no. 4 (December 1903): 405. 
therefore taken the liberty of informing you that I shall be in expectation of a decided answer from you on or before the $10^{\text {th }}$ of March next; after that date, I shall consider myself justified in acting as I shall see fit, on any repetition of the threats made by the before-mentioned Indian or his party.

I am, \&c., with respect, James D. Saules. ${ }^{205}$

Saules's letter is interesting in several respects. First of all, it suggests that Saules

was literate. This is not altogether surprising, given that literacy rates among northern blacks in 1850 ranged from 63 percent in Louisville, Kentucky to 97 percent in

Providence, Rhode Island. ${ }^{206}$ He also states that, for whatever reason, he could not leave his farm in the Willamette Valley, suggesting that he was no longer running his freight business and had permanently settled as a farmer. Finally, it reveals that Saules respected the legal infrastructure created by the American settlers and used the proper legal channels to fulfill request for assistance. This also shows that after a little over a year in the region, White's authority was firmly established. Yet while Saules is respectful toward White, he is not deferential; He essentially gave him an ultimatum to act or Saules would take the law into his own hands.

In his letter, Saules also refers to Cockstock having recently murdered several Indians. The incident in question happened in December of 1843. According to White, fifteen Molallas and Klamaths arrived near where White lived to visit with a Kalapuyan headman named Caleb. White was concerned about the intentions of the visitors, but allowed Caleb to slaughter one of White's oxen as food for the gathering. Once the visitors were sated, White seized the opportunity to present them with the same civil

\footnotetext{
205 U.S. Congress, Senate, Report of the Commissioner of Indian Affairs, $28^{\text {th }}$ Cong., 2d Sess., 1844 , Vol. 1, S.Doc. 1, serial 449, 502..

${ }^{206}$ William Jeynes, American Educational History School, Society, and the Common Good (Thousand Oaks: SAGE Publications, 2007), 82.
} 
compact and rules he offered to the Nez Perces and Cayuses. At this point, Cockstock joined the meeting, although White did not recognize him. The Molallas and Klamaths agreed to discuss matters further at a council scheduled for March 15, 1844. However, as the group left the proceedings to return home, half of the group, allegedly led by Cockstock, massacred the others in retaliation for acquiescing to White's request.

White, who claimed in his report to have known Saules well, responded to his letter by assembling a party of ten men to "secure the Indian without bloodshed.",207 However, on February 27, the party was thwarted by bad weather and Cockstock and his five Molalla companions were able to elude them. White decided to offer a $\$ 100$ reward, a considerable sum in 1844, for the successful capture of Cockstock. In the mid-1840s, the American settlers faced a chronic currency shortage, which likely heightened the reward's value. ${ }^{208}$ While White recognized that many settlers sought to kill Cockstock, his plan was to have him tried by the Nez Perces and Cayuses, whom he believed "would feel honored in inflicting a just sentence upon him." ${ }^{209}$ White also contended that such a settlement would save the "colony" from an Indian war "so much to be dreaded in our present weak and defenceless condition. ${ }^{, 210}$

On March 4, 1844, Cockstock and the five Molallas arrived in Oregon City in the early afternoon on horseback. The following description of the Cockstock Affair is culled exclusively from White's version of the events, one of only three primary source

\footnotetext{
207 U.S. Congress, Senate, Report of the Commissioner of Indian Affairs, 502.

${ }^{208}$ Dorothy Nafus Morrison, Outpost: John McLoughlin \& the Far Northwest (Portland: Oregon Historical Society Press, 1999), 432.

209 U.S. Congress, Senate, Report of the Commissioner of Indian Affairs, 503.

210 Ibid.
} 
accounts. According to White, they carried firearms and were "horribly painted." ${ }^{211}$ For the next several hours, the band rode from house to house in an intimidating manner and eventually crossed the Willamette River to a Kalapuyan village on the other side. According to a Kalapuyan headman, Cockstock attempted to recruit the villagers to "join him and burn the town that night." ${ }^{212}$ After the Kalapuyas refused, the band recrossed the river with an interpreter "for the purpose of calling the whites to an explanation for pursuing him with hostile intentions. ${ }^{, 213}$ As Cockstock and his companions returned to Oregon City, a crowd of settlers gathered where they were attempting to land, "some to take him alive and get the reward; others to shoot him at any risk to themselves, the wealthiest men in town promising to stand by them to the account of $\$ 1,000$ each." $" 214$ Both sides then began firing rounds at each other, with each claiming the other had fired first. At that point George LeBreton, the official recorder for the provisional government, rushed unarmed at Cockstock and received three shots to his right arm. Cockstock then wrestled LeBreton to the ground and stabbed him with his knife. At that point, Saules's neighbor Winslow Anderson appeared and smashed Cockstock's skull with the barrel of his rifle, killing him instantly. The five Molallas then fired guns and shot arrows at the settlers, wounding William H. Wilson and Sterling Rogers, before they fled among the rocks on the east side of the town. The settlers followed them with firearms, killing a horse and wounding one of the Molallas, which ended the fracas. LeBreton was rushed to

\footnotetext{
211 Ibid.

212 Ibid.

213 Ibid.

214 Ibid.
} 
Fort Vancouver to received medical attention but soon died from lead poisoning. Rogers also died from his wounds, although Wilson survived. ${ }^{215}$

Francois Norbert Blanchet, a French Canadian Catholic missionary who first arrived in the Oregon Country in 1844, was also in Oregon City on March $4^{\text {th }}$ and his version of the Cockstock Affair, written soon after the event, deviates from White's in several respects. ${ }^{216}$ He refers to Cockstock as the chief of the Molallas and claims that he was innocent of any massacre of Indians. He claims that Cockstock arrived in Oregon City with four other men to contest the $\$ 100$ bounty and proclaim his innocence of all charges. Blanchet also contends that once Cockstock crossed the river to the Indian village, the townspeople planned to apprehend him in order to claim the reward. However, John McLoughlin's store-clerk protested: "That Indian is a good man, you should not molest him; if you do, you will repent!"217 According to Blanchet, on Cockstock's return to Oregon City, LeBreton and Anderson demanded Cockstock surrender. When he refused, an unnamed settler ordered Anderson to shoot. Anderson then wounded Cockstock, who allegedly only fired on LeBreton in self-defense. In his book, Blanchet also included a letter written three days after the event by Rev. Modeste Demers, a fellow Catholic missionary also present at the scene. Demers worked closely with the Chinookan people of the region and was apparently fluent in their language.

\footnotetext{
${ }^{215}$ In 1857, Wilson gave his account of the incident. His version mostly adheres to White's account with one notable exception: he never mentions Winslow Anderson's role and instead claims to have fired the fatal shot that felled Cockstock. He also claimed to have been a member of the party White assembled to find Cockstock. See Samuel Asahel Clarke, Pioneer Days of Oregon History (J.K. Gill Company, 1905), 602-604.

${ }^{216}$ For Blanchet's version see Francis Norbert Blanchet, Historical Sketches of the Catholic Church in Oregon, During the Past Forty Years, 1878, 145-148.

217 Ibid., 146.
} 
Demers corroborated Blanchet's story, adding that Anderson not only shot and attacked Cockstock with the barrel of his rifle but that he also later split his head apart with an axe. $^{218}$ Demers concluded that the killing of Cockstock was "true murder; based upon the extremely rash and unjustifiable action of poor LeBreton who will pay dearly for his apostasy and crime." $" 219$

It is impossible to determine the veracity of any account of the Cockstock affair, especially since French Canadian missionaries viewed the American overlanders as rivals and had good reason to denigrate them. On the other hand, Blanchet and Demers' perceptions of the event demonstrate how differently the French Canadian missionaries viewed the Native people of the region, as well as their skepticism toward the intentions of American settlers, which Blanchett refers to as "another kind of savageness.",220 Several years later, Blanchet reflected on the event and insisted that "all the Indian tribes were never so peaceable as they were then, having no reason to molest them, as their fisheries, hunting-places and camas prairies had not yet been taken away from them." ${ }^{, 21}$ According to White's documentation, following the events of March $4^{\text {th }}$, seventy armed Native people from The Dalles arrived in Oregon City demanding an explanation for Cockstock's death. White, concerned that the incident would lead to widespread conflict, brokered a settlement by presenting Cockstock's widow with two blankets, a dress, and a handkerchief, emulating the traditional Native practice of "covering the

\footnotetext{
218 Ibid., 147.

219 Ibid.

${ }^{220}$ Ibid., 148.

221 Ibid.
} 
dead. ${ }^{, 222}$ His handling of the situation suggests the influence of McLoughlin, who usually advocated for solving disputes according to Native customs. According to historian Frances Fuller Victor, McLoughlin himself handled the actual transaction and considered the death of Cockstock an unprovoked "assassination." 223 This is entirely possible, as White was friendly with McLoughlin and relied on credit extended by Fort Vancouver to fund his activities. Furthermore, McLoughlin was an ideal figure to oversee the transaction. As a representative of the multiethnic fur trade, he had ample experience with similar negotiations. There is evidence that White was worried that such a settlement might not be enough to quell future violence. In his report, White mused, "I believe it morally impossible for us to remain at peace in Oregon, for any considerable time, without the protection of vigorous civil or military law. ${ }^{, 224}$

While White's solution proved effective, some American settlers objected him brokering any deals. The settlers responded to the incident in a manner far different than McLoughlin had to previous instances of violent conflict with Native peoples. Alanson Beers, one of the provisional government's three executives, objected to McLoughlin's recommendation of gift giving and suggested that "the idea should be hooted out of countenance, that they allowed Indians to be murdered, and paid for it with blankets."225 On March $9^{\text {th }}, 1844$, five days after the Cockstock Affair, the executive committee held a public meeting in French Prairie in response to fears of a major Native revolt. The settlers voted to form the Oregon Rangers, a voluntary organization of twenty-five mounted

\footnotetext{
222 Ruby and Brown, Indians of the Pacific Northwest, 51.

223 Bancroft and Victor, History of Oregon, Volume One, 283-284.

224 U.S. Congress, Senate, Report of the Commissioner of Indian Affairs, 506.

225 Bancroft and Victor, History of Oregon, Volume One 1888, 282.
} 
riflemen that was the first military organization ever assembled in the Oregon Country. ${ }^{226}$ However, relations between settlers and Natives remained peaceful and the Oregon Rangers saw very little action in the subsequent months. According to Frances Fuller Victor, "The formation of the company was in fact a mere piece of braggadocio, intended quite as much to alarm the Hudson's Bay Company as to awe the natives."227 This also suggests the extent to which the Cockstock Affair can be seen as a product of regional tensions between the recently arrived overlanders and the various previous inhabitants of the region.

\section{The Saules-Pickett Dispute}

In the weeks following the Cockstock Affair, the mood of fear and trepidation continued in the Willamette Valley as settlers experienced what they perceived as another potential uprising of Native people. However, this time Saules played a central rather than peripheral role. On May $1^{\text {st }}, 1844$, Justice of the Peace Robert Moore, a member of the 1839 Peoria Party, issued Sheriff Joseph Meek, the legendary fur trapper turned law enforcement officer, a warrant for the arrest of "Saul [sic], a man of color.",228 In his deposition, the plantiff, Charles E. Pickett, claimed Saules had "threatened to incense the Indians against his property, to destroy the same; and that he...verily believes that unless measures are taken to prevent [Saules]...he will carry those threats into execution." On May $3^{\text {rd }}$, Meek returned with Saules, two witnesses, and a jury of six men. The two

${ }^{226}$ Gray, A History of Oregon, 1792-1849, 241-248; Mcclintock, "James Saules, Peter Burnett, and the Oregon Black Exclusion Law of June 1844," 126-128.

227 Bancroft and Victor, History of Oregon, Volume One, 285.

${ }^{228}$ U.S Congress, United States Office of Indian Affairs, Annual Report of the Commissioner of Indian Affairs, $29^{\text {th }}$ Cong. $1^{\text {st }}$ Sess., 1846, 182. 
witness, both recently arrived American immigrants, corroborated Picket's deposition. They claimed, "Indians had come in a menacing manner; and that Saul [sic] said he would stand for the Indians' rights; and that [Saules] was armed and prepared to do so; and that the Indians would burn and destroy his house and property."229 The jury, also comprised of American immigrants, three of whom arrived via the Great Migration of 1843, found Saules guilty of all charges. However, Moore determined that the charges against Saules were "of a higher character than the Oregon laws have cognizance of" and "that the United States sub Indian agent, Dr. Elijah White, is the proper officer to take cognizance of him. ${ }^{, 230}$ Moore then had Saules delivered to White.

Unlike the Cockstock Affair, which is covered extensively in several early Oregon history books, almost nothing is known about the particulars of the Saules-Pickett dispute. The only reference that exists beyond the scant legal documents is from Frances Fuller Victor: "Saules, the negro who had complained of Cockstock, was himself arrested for joining the Clackamas Indians in making threats against the life and property of Charles E. Pickett." ${ }^{231}$ Why such threats were made and why Saules was compelled to stand for the Natives' rights remains unknown, as well as what those "rights" referred to. In addition, Pickett's biographer Lawrence Clark Powell does not mention the case, even though he discusses other events that took place in the spring of 1844 in considerable detail. What can be determined is that Saules did not receive a fair trial. For example, at

\footnotetext{
229 Ibid.

230 Ibid.

231 Bancroft and Victor, History of Oregon, Volume One, 284.
} 
least one juror, James W. Nesmith, was Pickett's close friend and traveling companion. ${ }^{232}$ Four jurors, Nesmith, William C. Dement, Philip Foster and Sydney W. Moss, were members of an organization led by Pickett, the Pioneer Lyceum and Literary Club. ${ }^{233}$ Furthermore, it does not appear that Saules, who was denied citizenship due to his race, was given any legal representation or anything resembling a jury of his peers. The provisional government was not unusual in this regard, as no African American ever served on a jury in the United States until $1860 .^{234}$

While many scholars have addressed Saules's arrest and conviction in relation to Oregon's first black exclusion, no one has considered the identity of the plantiff, Charles E. Pickett. Pickett was a brash and eccentric southerner who arrived in Oregon at the age of 24 as part of the Great Migration of 1843 . Yet he did not fit the profile of the typical overlander. He was the scion of a prominent colonial family of Virginia who was raised on his wealthy father's fruit plantation. Unlike most of his fellow immigrants, Pickett was college-educated and adamantly pro-slavery. He was also a self-professed philosopher and journalist with impressive political connections (future president James K. Polk was a family friend) and an aversion to manual labor. During the three years he lived in Oregon, Pickett was active in the provisional government, secretary of the aforementioned literary club, a member of the Oregon Rangers, and editor of the

\footnotetext{
${ }^{232}$ Lawrence Clark Powell, Philosopher Pickett: The Life and Writings of Charles Edward Pickett, Esq., of Virginia, Who Came Overland to the Pacific Coast in 1842-43 and for Forty Years Waged War with Pen and Pamphlet against All Manner of Public Abuses in Oregon and California; Including Also Unpublished Letters Written by Him from Yerba Buena at the Time of the Conquest of California by the United States in 1846-47 (University of California Press, 1942), 10,18.

${ }^{233}$ Various, The Quarterly of the Oregon Historical Society, Vol. IVMarch, 1903-December, 1903, ed. Frederic George Young, 2012, 390, http://www.gutenberg.org/ebooks/41493.

${ }^{234}$ Michelle Alexander, The New Jim Crow: Mass Incarceration in the Age of Colorblindness (The New Press, 2010), 117.
} 
Flumgudgeon Gazette, the first newspaper west of the Rocky Mountains. In 1845, Pickett was elected Clackamas County judge, even though he admitted that he had never studied nor practiced law. ${ }^{235}$ On the other hand, Pickett ran afoul of the Methodist establishment and was referred to by Methodist missionary Rev. L.H. Judson as "a spunge and a loafer and above all a debaucher with Indian women... ${ }^{, 236}$ In 1847, President Polk appointed him to replace Elijah White - another Methodist with whom Pickett had a bitter feud — as Indian subagent, a position he declined following his relocation to California. For the next several decades, Pickett was a prolific pamphleteer and critic of the California political scene, although he returned to Oregon in 1857 to agitate for slavery during the debate over the state constitution. ${ }^{237}$ Perhaps the most notable incident in Pickett's life came in 1874 , when he served eight months in jail for physically dragging a California Supreme Court justice off his seat on the bench. ${ }^{238}$

Pickett also engaged in land speculation during his time in the Willamette Valley, much to the chagrin of the Methodists of Oregon City, who held a monopoly on the best farmland in the region. This resulted in a series of events, one of which closely resembles what is known about the 1844 Saules-Pickett dispute. Despite the fact that the Methodists had encouraged settlement in Oregon through their writings, the influx of American settlers in the early 1840 s resulted in heated challenges to Methodist land claims. Sometime in 1844 , Pickett defiantly squatted on a 640 -acre plot of land already claimed by the Methodists at the confluence of the Willamette and Clackamas rivers in Oregon

\footnotetext{
235 Powell, Philosopher Pickett, 28.

236 Ibid., 9.

237 Ibid., 70.

${ }^{238}$ Ibid., 92-96.
} 
City. To establish his claim, he then engaged in the first manual labor of his stay in Oregon, growing grain, cabbages, and potatoes. According to his biographer, "The [Methodist] church was unsuccessful in ousting Pickett, even though it went so far as to incite the Indians to attempt to murder him [emphasis added], and other land-hungry settlers then poured in and the missionaries' monopoly was broken." ${ }^{239}$ His friend and Saules-Pickett juror James W. Nesmith, considered Pickett's move a triumph, noting that "the Mission brought suit to oust him, in which, aided by all the lawyers in Oregon, they were unsuccessful.. ${ }^{, 240}$ Pickett had no intention of settling on his newfound property, as he had already resolved to move to California. Instead, he subdivided the property and later placed an advertisement for "town lots" in the February 5, 1846 edition of the Oregon Spectator. ${ }^{241}$ While there is no evidence that the Saules-Pickett dispute was rooted in this same land dispute, Pickett's subsequent behavior suggests that this was the case. This also raises the question of whether Saules and his Native companions were working on behalf of the Methodists when they allegedly threatened Pickett.

Pickett was also an outspoken white supremacist, a fact that probably did not endear him to the non-white or mixed-race residents of the Willamette Valley. Even though many American overland settlers conceived of race in hierarchical terms with Anglo-Saxons on top, Pickett's views were extreme even in this context. For example, when President Polk appointed Pickett as Indian subagent in 1847, many Oregonians expressed astonishment. Some referred to a letter he wrote to the Oregon Spectator that

\footnotetext{
239 Ibid., 11.

240 Ibid., 10.

241 Ibid., 15.
} 
year in which he instructed those traveling to California to shoot Native people on sight: "After you get to the Siskiyou Mountains, use your pleasure in spilling blood...my only communication with these treacherous, cowardly, untamable rascals would be through my rifle." Pickett was also skeptical regarding the possibility for peaceful relations with Native people, claiming "philanthropy must be set aside in cases of necessity, while selfpreservation here dictates these savages being killed off as soon as possible."242 Furthermore, Pickett was in favor of the expansion of slavery into the Far West. And according to Powell, Pickett "looked upon the Indians as equivalent to the Negroes-a slave race. ${ }^{, 243}$ Few settlers wrote as prolifically about race, offering a vivid example of the settler colonialist mentality. In 1857 , he issued a jeremiad to the veterans of the Mexican War, warning of politicians with "false humanitarian notions" who sought to "raise the inferior orders or colored castes on a level with the white race." 244 He claimed that such advocates for racial equality would force "ye women of Caucasian lineage...to be enfolded as brides in an Ethiop's brawny embrace, and become the dams of a rising breed of tawny hybrids." ${ }^{245}$ In this passage, Pickett stressed the importance of white women's role in preserving racial differences in the nascent settler colonies of the multiethnic Far West.

\section{Oregon's First Black Exclusion Law}

\footnotetext{
242 Ibid., 34.

243 Ibid., 39.

${ }^{244}$ Charles Edward Pickett, Address To The Veterans Of The Mexican War: Embodying A Historical Contrast Of The Two Great Political Parties Of The United States On Vital Issues (Kessinger Publishing,, 2007), 21.

245 Ibid.
} 
Saules's arrest and conviction ended his efforts to support his family as a yeoman farmer in the Willamette Valley. The provisional government had no jail or prison in the spring of 1844, so White apparently held Saules in custody at his own residence. After several weeks, White asked Saules to leave the Willamette Valley and seek employment at the Methodist mission at Clatsop Plains on the south side of the mouth of the Columbia River. This suggests that the Methodist missions of the Pacific Northwest, despite largely abandoning their project of converting Native people, were still places that would accept a black man as an employee. Perhaps Saules, like his friend Winslow Anderson, already had a history of working for the Methodists. Saules obeyed White's orders but was unable to find work with the mission. What happened to Saules's land claim near Willamette Falls remains unknown, as is whether he was even able to sell it. According to White, in a letter to the U.S. secretary of war, Saules "remains in that vicinity with his Indian wife and family, conducting, as yet, in a quiet manner..."246 White then drew a sweeping conclusion from the Saules-Pickett dispute: "[Saules] ought to be transported, together with every other Negro, being in our condition dangerous subjects. Until we have some further means of protection, their immigration ought to be prohibited. Can this be done?"247 White offered no explanation for why Saules's alleged activities necessitated the wholesale deportation of all black residents of the Oregon Country, as well as a prohibition on future black settlement. The urgency of his request is also striking, since historian Thomas McClintock estimated that fewer than 15 blacks resided

\footnotetext{
246 Annual Report of the Commissioner of Indian Affairs, 182.

247 Ibid.
} 
in the Oregon Country at the time Saules was arrested. ${ }^{248}$ Furthermore, there are no surviving records indicating that any other black person was charged with any crime prior to Saules's arrest.

White's request to the secretary of war went unheeded since the U.S. government had no jurisdiction over the region, but the provisional government took immediate action. On June 18, 1844, the executive committee held a meeting in which they recommended "that the laws of Iowa be taken into consideration concerning blacks and mulattoes, and that law be enacted for the punishment of offenders inciting the Indians against the whites."249 This was a clear reference to the Saules-Pickett dispute, which occurred less than two months earlier. On June 25, 1844, Peter Burnett, recently elected to the legislative committee, introduced a bill which proposed that "when any free negro or mulatto shall have come to Oregon, he or she ... shall remove from and leave the country within the term of two years for males, and three for females." The law applied both to newcomers as well as those, like Saules and Anderson, who had lived in the region for several years. The bill, which was actually more severe than Iowa's, required corporal punishment for those who refused to leave. If a black person remained in Oregon beyond the stated terms, he or she would "receive upon his or her bare back not less than twenty nor more than thirty-nine stripes, to be inflicted by the constable of the country. ${ }^{, 250}$ Such whippings would be repeated every six months until the guilty party

\footnotetext{
248 Mcclintock, “James Saules, Peter Burnett, and the Oregon Black Exclusion Law of June 1844,” 125.

249 Bancroft and Victor, History of Oregon, Volume One, n. 429.

250 Elizabeth McLagan and Oregon Black History Project, A Peculiar Paradise: A History of Blacks in Oregon, 1778-1940 (Georgian Press, 1980), 186.
} 
left the region. On June 26, 1844, the legislative committee voted six to two to pass Oregon's first black exclusion law.

Many historians have explained Oregon's 1844 black exclusion law by drawing a connection between the Cockstock Affair and the Saules-Pickett dispute based on Saules's involvement in both. The first was Frances Fuller Victor, who wrote in 1888: “The trouble occasioned by Winslow and Saules aroused a strong prejudice against persons of African blood, which was exhibited in a communication sent by White to the secretary of war, inquiring if the emigration of negroes could not be prohibited, and in the subsequent legislation of the colonists." 251 While Victor, who did not move to Oregon until 1864, offered no evidence for this link, it has proven influential. In 1982, Quintard Taylor wrote, "Local whites blamed Saules and [Winslow] for the [Cockstock Affair] and threatened Saules's life." 252 In addition, Taylor claims that both Saules and Anderson were exiled to Clatsop Country. Again, Taylor cites no sources beyond White's letter and the surviving documentation of the Saules-Pickett dispute, none of which supports either of these assertions. ${ }^{253}$ In his comprehensive 1991 examination of Oregon's first black law, Thomas McClintock contends that White's request for a black exclusion law was "based on the Cockstock affair and the Saules-Pickett dispute." ${ }^{254}$ McClintock also credits Victor as the only historian to mention the Cockstock Affair and the SaulesPickett dispute as factors leading up to the passage of black exclusion.

But were the Cockstock Affair and the Saules-Pickett dispute necessarily linked?

\footnotetext{
251 Bancroft and Victor, History of Oregon, Volume One, 284.

252 Taylor, "Slaves and Free Men," 156.

${ }^{253}$ In 2013, R. Gregory Nokes reiterated these claims, citing Quintard Taylor, see Nokes, Breaking Chains, 53.

${ }^{254}$ Mcclintock, “James Saules, Peter Burnett, and the Oregon Black Exclusion Law of June 1844,” 128.
} 
Both events involved Natives, blacks, and whites, and occurred within weeks of each other. Moreover, it is also likely that the Cockstock Affair made settlers fearful of a Native uprising. Therefore, Saules's alleged provocations occurred during a tense period in which white settlers felt vulnerable. Yet while it is logical to link the two, there is no evidence in the historical record suggesting that one event had anything to do with the other. As for Victor's claim that the two events “aroused a strong prejudice against persons of African blood," it is difficult to believe such prejudice did not already exist, given the racialist views of the immigrants of 1843. And as McClintock acknowledges, the issue is complicated by the fact that no members of the provisional government ever mentioned the Cockstock Affair or the Saules-Pickett dispute as a justification for the law. Settler and historian William H. Gray does not mention either event in his attack on Peter Burnett for drafting the initial black exclusion law, nor did Burnett in his defense of the law. Furthermore, Elijah White, in his inquiry to the provisional government about the possibility of expelling blacks from Oregon, never mentioned the Cockstock Affair as an inspiration, an event in which he had had considerable involvement with both Saules and Winslow.

Burnett's justification for the 1844 black exclusion law was to prevent slavery from taking root in the region. In fact, section one of the act reads, "That slavery and involuntary servitude shall be for ever prohibited in Oregon. ${ }^{, 255}$ And despite the pervasiveness of racialism, most overland settlers of the 1840 s remained anti-slavery Democrats. The majority came from the Old Northwest, where the question of whether to

${ }^{255}$ McLagan and Project, A Peculiar Paradise, 185. 
allow slavery was the most heated political issue of the day. In addition to banning slavery, many of these states also had black exclusion laws. Burnett wrote of slavery in a letter to the Jefferson Inquirer in 1845: "We are in a new world, under most favorable circumstances, and we wish to avoid most of these great evils that have so much afflicted the United States and other countries." ${ }^{256}$ Many settlers wanted to keep slavery out of Oregon to prevent the unfair competition of slave labor, as well as to avoid the stratified social relations of a plantation economy. John Minto invoked this idea to explain why he wanted to emigrate from Missouri to Oregon in 1844: "I am not satisfied here ... I'm going to Oregon, where there'll be no slaves, and we'll all start even."257 This echoes the Jeffersonian ideal of an agricultural society comprised only of free whites and, therefore, devoid of class distinctions.

Yet Burnett's claim that the law was an anti-slavery measure was disingenuous, since slavery was already banned according to the provisional government's 1843 Organic Code. Furthermore, in addition to being anti-slavery, many white settlers were also anti-black. They believed that if slavery were ever ended, as many assumed it would, emancipated slaves would be transformed into a disruptive population of free blacks. According to settler Jesse Applegate, who was eventually instrumental in repealing Oregon's first black exclusion law in 1845, "Many of those people hated slavery, but a much larger number of them hated free negroes worse even than slaves... ${ }^{258}$ In his 1880 memoir, Burnett defended his black exclusion law and argued that, because the Organic

\footnotetext{
256 Ibid., 29.

257 Berwanger, The Frontier against Slavery, 24.

${ }^{258}$ McLagan and Project, A Peculiar Paradise, 29.
} 
Code of 1843 denied blacks voting rights or the ability to hold office, a disenfranchised race would be a potentially dangerous burden on the rest of the population: "Placed in a degraded and subordinate position ... they are left without adequate motive to waste their labor for that improvement which, when attained, brings them no reward. ${ }^{, 259} \mathrm{He}$ concluded that "surely every intelligent and independent man of color would have scorned the pitiful boon offered him of a residence under conditions so humiliating." 260 While Burnett was anti-slavery, it is evident that he did not envision the possibility of grating black people equal rights, nor did he see a place for them in Oregon.

It is important to place the provisional government's initial justification of black exclusion, that the "law be enacted for the punishment of offenders inciting the Indians against the whites," in a larger historical contest. Beginning in the eighteenth century, many early Americans had dreaded the potential alliance of two marginalized groups, black people, both free and enslaved, and American Indians. Historians Peter Linebaugh and Marcus Rediker argue that such fears were heightened prior to the American Revolution, due to formation of multiethnic resistance movements in eastern port cities: "At the peak of revolutionary possibility, the motley crew appeared as a synchronicity or an actual coordination among the 'risings of the people' of the port cities, the resistance of African American slaves, and Indian struggles on the frontier."261

What few scholars mention, with the exception of Gray H. Whaley, is the possible influence of actual black-Native collaboration in the southeastern United States

\footnotetext{
259 Burnett, Recollections and Opinions of an Old Pioneer, 220.

260 Ibid., 221.

261 Peter Linebaugh and Marcus Rediker, The Many-Headed Hydra: Sailors, Slaves, Commoners, and the Hidden History of the Revolutionary Atlantic (Verso, 2000), 213-214.
} 
on the adoption of black exclusion laws in Oregon. The Second Seminole War, the most costly Indian war in U.S. history up to that point, had just ended in 1842. Beginning in the eighteenth century, runaway slaves from the South found refuge among the Seminoles in Spanish-occupied Florida. The Seminoles had refused all attempts to retrieve the slaves. In the First Seminole War (1814-19), Georgia's militia attempted again to retrieve the slaves, only to be humiliated by the combined resistance of Seminole and black fighters. In 1835, the U.S. government tried to remove the Seminoles following the acquisition of Florida. The Seminoles and blacks again rose up, this time against the might of the U.S. Army. The Second Seminole War lasted seven years, cost the U.S. government \$20 million (approximately \$500 million in today’s currency), and resulted in the deaths of approximately 1,500 American soldiers, as well as 1,500 Seminoles and blacks.

While no one in the provisional government ever specifically mentioned blackNative collaboration in the southeastern United States as a rationale for black exclusion, there is some evidence that it may have been a factor in the adoption of race laws. For example, many of the men who comprised the provisional government were educated and literate; they were almost certainly aware of what had happened in Florida only a few years prior. Especially since Missouri senator and Oregon booster Thomas Hart Benton was the chairman of the senate Committee on Military Affairs for the duration of the war and was obsessed with bringing it to a satisfying end. More specifically, two early members of the Oregon Rangers, Captain Charles Bennett and Sergeant Thomas Holt, 
actually served as dragoons in the Second Seminole War. ${ }^{262}$ All of these factors likely led the provisional government to attach added significance to the alleged actions of Saules and his accomplices against a white settler.

There were also inherent similarities between the situations in Florida and Oregon as American expansionists saw both as part of same larger project. For example, in late 1830 s and early 1840 's, Senator Benton, argued forcefully for the colonization of both regions by Anglo American settlers. In 1842, following the disastrous end of the Second Seminole War, Congress passed Benton's Armed Occupation Act, which offered settlers 160 acres of free land in Florida if they were willing to cultivate it and bear arms to protect it. ${ }^{263}$ Benton proposed the bill at the same time he had urged the passage of his colleague Senator Lewis Linn's very similar 1841 Oregon Territorial Bill. General Thomas Jesup, the commander of U.S. forces in the Second Seminole War, applauded Benton's idea of using settlers rather than soldiers to conquer indigenous peoples: "No force employed against [the Seminoles]...has ever been able to catch them...Let them be crowded by settlers, and that which has invariably occurred throughout the whole history of our settlements will occur again, they will not only consent to remove, but will desire it as the greatest benefit the nation can confer upon them." Historian Paul W. Gates has argued that the later Oregon Donation Land Law can be linked to the success of Benton's Florida bill as both were intended to give "land to settlers in these territories where they

\footnotetext{
262 Clarke, Pioneer Days of Oregon History, Volume Two, 588.

${ }^{263}$ James W. Covington, "The Armed Occupation Act of 1842," The Florida Historical Quarterly 40, no. 1 (July 1, 1961): 41-52.
} 
might help to reduce the Indian menace."264

Perhaps the expulsion of Saules and his family from the Willamette Valley, as the well as the passage first black exclusion law, can also be explained in terms of the logic of settler colonialism itself. When settler colonists arrive in a new region, they must contend with the previous inhabitants and determine who belongs in the community and who must be excluded. In the 1840s, the cultural and ethnic hybridity of the Oregon Country clearly upset these categories and presented a challenge to the newly arrived American settlers. For instance, Saules was an example of a person who could not be neatly reduced to the binary categories of "colonizer" and "colonized." Lorenzo Veracini argues that settler colonialism creates a triangular "system of relationships comprising three different agencies: the settler colonizer, the indigenous colonized, and a variety of differently categorized exogenous others. ${ }^{265}$ For Veracini, settler colonizers attempt to manage these relationships by establishing which indigenous or exogenous inhabitants are righteous and therefore worthy of inclusion in the settler body politic, as well as which are degraded and must be excluded. ${ }^{266}$ However, Vericini insists that these categories are never fixed and "are open to ongoing and protracted contestation, are never neatly separate...and are continually tested and reproduced.. ${ }^{267}$ For example, the fur trade practice of intermarriage resulted in a generation of mixed-race children difficult to define as either indigenous or exogenous. Some early American settlers, such as Joseph

\footnotetext{
${ }^{264}$ Paul W. Gates., History of Public Land Law Development (Washington, D.C.: Wm. W. Gaunt \& Sons, 1987), 390.

${ }^{265}$ Lorenzo Veracini, “The Settler-Colonial Situation,” Native Studies Review 19, no. 1 (July 2010): 101.

266 Ibid., 104.

267 Ibid.
} 
Meek, also married Native women and had children with them. Some of these children, particularly the male offspring of prominent white American settlers like Meek, would be included into the settler body politic, even though the practice of intermarriage was soon discouraged and later made illegal.

On the other hand, following the Saules-Pickett dispute, Saules was classified as something akin to what Veracini describes as an "abject other," someone "permanently excluded from the settler body politic" who has "lost their indigenous or exogenous status. ${ }^{268}$ In the Saules-Pickett dispute, unlike his role in the Cockstock Affair, Saules did not side with the American immigrants. Instead he aligned himself with the colonized to resist the colonizers at a moment at which the region had yet to be conquered. Because of this, Saules, along with every other black person in the region, came to be seen as a dangerous racialized "other." According to Veracini, such abject others become "disconnected from their land and communities and are the subject of segregative practices that... are principally characterized by restrained mobility (the absolute opposite of a settler capacity for unfettered mobility). ${ }^{, 269}$ This was likely a crushing blow to man who had previously experienced a remarkable amount of mobility in the Pacific Northwest and on deep sea voyages such as the U.S. Ex. Ex.

Despite the passage of the black exclusion law, Saules did not leave the Oregon Country. However, he never lived in the Willamette Valley again. The fluid social and cultural middle ground Saules once navigated had become severely challenged by the overlanders. The middle ground would continue to fade as thousands more Americans

\footnotetext{
${ }^{268}$ Veracini, Settler Colonialism, 27-28.

${ }^{269}$ Ibid., 28.
} 
arrived in the region and marginalized the previous inhabitants. Furthermore, in the next two years, tensions between the United States and Great Britain over which empire would ultimately claim the region increased to the point that many feared armed conflict. These imperial struggles would directly affect Saules, who again experienced displacement and humiliation. Even so, changes within the composition of the provisional government allowed Saules to regain much of his cherished mobility and visibility. Unfortunately for Saules, his new freedoms would prove fleeting. 


\section{Chapter Three: Saules in Exile, The Oregon Question, and the Return of Black Exclusion}

As the settler colonization of the Oregon Country continued in the mid-1840s, one might assume that the provisional government would hold fast to its segregative practices. Yet this was not the case. James D. Saules and other non-whites did not simply go away as many settlers had wished. Even though the provisional government could pass laws, it had difficulty enforcing them. This was due to both the vastness of the Oregon Country and the lack of an effective police force or jails to house criminals. Therefore, the heterogeneous middle ground of the lower Columbia continued to exist, in a somewhat muted form, for several more years. And while the provisional government denied Saules citizenship and the right to participate in the provisional government, he was a significant presence in the region's economic and cultural life in the mid-to-late 1840s. However, the American settlers continued to express fear and antipathy toward the ethnic complexity of the Oregon Country. Furthermore, Oregon also became embroiled in international imperial wrangling, the outcome of which accelerated the Americanization of the Pacific Northwest. This chapter will show how Saules attempted to steer a course through these regional shifts and, at times, even resist them, as well as how difficult this became once the region was officially incorporated into the United States.

By December of 1844, some members of the provisional government expressed misgivings about the severity of the black exclusion law passed the previous June. On December 16, the executive committee recommended to the legislative committee "that 
the act passed by this assembly...relative to blacks and mulattoes, be so amended as to exclude corporal punishment, and require bonds for good behavior in its stead." 270 Historian Thomas McClintock argued that the executive committee essentially requested that the legislative committee lift the exclusion law and instead regulate the behavior of free blacks through bonds. On December 18, 1844, Peter Burnett, who still led the legislative committee, responded to their request by proposing an amendment to the original law that only removed the flogging provision. This was obviously only a halfway measure, as Burnett retained the exclusion provisions of the June law. Instead, his amendment proposed that, if a black person refused to leave the Oregon Country, he or she would be arrested and brought before a justice of the peace. If found guilty, an officer would then auction off the guilty party as a laborer to the lowest bidder. Whomever agreed to hire the "free black or mulatto" for the shortest term of service would "enter into a bond...binding himself to remove said negro or mulatto out of the country within six months after such service shall expire."271 In his autobiography, Burnett failed to mention the executive committee's recommendation and instead took credit for the removal of the flogging provision: "By the December session of 1844 I had found another and less objectionable remedy, and promptly adopted it."272 He even went as far as to claim that he and the others on the legislative committee were not responsible for the original lash law since "we ourselves corrected the error.,"273

\footnotetext{
${ }^{270}$ William Henry Gray, A History of Oregon, 1792-1849, 382.

${ }^{271}$ Burnett, Recollections and Opinions of an Old Pioneer, 215.

${ }^{272}$ Ibid., 218.

${ }^{273}$ Ibid.
} 
In the summer of 1845 , Saules and the other black people living in the region received even better news. On July 24, the original Organic Code of 1843 was replaced with a new set of laws which, among other changes, repealed the black exclusion law in its entirety. Many historians have attributed this change to the election of Jesse Applegate to the legislative committee, as well as the temporary absence of Burnett from the new provisional government. ${ }^{274}$ Like Burnett, Applegate was one of the leaders of the Great Migration of 1843 and a fervent opponent of slavery. Yet unlike many of his fellow settlers who were Democrats, Applegate was a Whig, a party formed in opposition to the policies of President Andrew Jackson. While Applegate was somewhat skeptical regarding whether white and black people could live together harmoniously, he wrote of emancipated blacks in 1865 that "if we retain [the Negro] among us, for our good as well as his, we must take him like Onesimus, 'a brother and an equal., ${ }^{, 275}$ In addition to repealing the black exclusion law, Applegate and others urged a new amendment banning slavery in the region. In the 1840s, Applegate's political views, coupled with his friendly relationship with John McLoughlin and the $\mathrm{HBC}$, led many settlers to refer to him as a sycophant of the British. ${ }^{276}$ Historians Dorothy O. Johansen and Charles M. Gates claimed that the revised provisional government of 1845 was due to an influx of more moderate and politically experienced settlers who sought "a more conservative and efficient government." Unlike the first, this government would be less hostile toward the McLoughlin and the HBC. Still, as in 1843, only "free male descendents of a white man"

\footnotetext{
${ }^{274}$ Nokes, Breaking Chains, 49.

275 Joseph Schafer, “Jesse Applegate: Pioneer, Statesman and Philosopher," Washington Historical Quarterly 1, no. 4 (January 4, 2010): 232.

${ }_{276}$ Dorothy O. Johansen, Empire of the Columbia: A History of the Pacific Northwest (Harper Collins, 1967), 244.
} 
were eligible for citizenship, meaning that Saules, although technically an American, could not participate in the civil society.

The new provisional government also furthered the Americanization of the region through its new land office, which was used to record claims and sales. This office provided white American settlers with an advantage in land ownership by failing to protect the traditional lands of indigenous peoples. The official position of the provisional government toward Native land was the same as U.S. federal Indian policy circa 1843: the government promised not to seize Native lands without permission or remuneration. ${ }^{277}$ However, in practice, the provisional government disregarded any notion of "Indian Country" and honored land claims that obviously pre-empted Native land. And because the land office lacked the scientific knowledge and equipment to formally survey the land, they often used Native villages and resource sites to mark their claims. ${ }^{278}$ Many white settlers also completely ignored Native land claims, likely assuming that Indian removal and disease would clear the way for the inevitable white settlement of the Oregon Country.

\section{Saules and the Oregon Boundary Dispute}

At the time of the repeal of the black exclusion law, Saules was apparently residing on Cape Disappointment at his original location overlooking Baker Bay. While the Willamette Valley was no longer a middle ground in which people of various ethnic backgrounds encountered and accommodated each other, the community that lived near

\footnotetext{
${ }^{277}$ Whaley, Oregon and the Collapse of Illahee, 161.

${ }^{278}$ Ibid.
} 
the mouth of the Columbia seemed to retain more of the fluid, heterogeneous quality of Oregon prior to the Great Migration of 1843. Although Elijah White believed that Saules failed to gain employment with the Methodist mission at Clatsop Plains following his expulsion, Historian Elizabeth McLagan claims he worked at the mission, located near Cape Disappointment on the south side of the mouth of the Columbia, until it closed in $1846 .^{279}$ This is corroborated by the recollections of American settler John Minto, who remembered meeting a mission cook named "J.D. Sauls" in Clatsop County circa 1844. ${ }^{280}$ And the fact that the Methodists were willing to employ Saules, as they had employed his friend Winslow Anderson at Wascopam, suggests their continued willingness to hire non-white workers.

This is corroborated by Clatsop Plains resident Silas B. Smith's vivid recollections of Saules performing fiddle tunes at various public gatherings in Clatsop County circa 1845-1846. Smith was the son of a Clatsop woman named Celiast (the daughter of Clatsop Chief Coboway) and Solomon H. Smith, an American overland settler and schoolteacher who arrived in the region in 1830 s. ${ }^{281}$ Solomon Smith and Celiast worked at the mission and operated a ferry service across the Columbia as early as 1840. Their son, Silas, who later practiced law in New Hampshire, remembered Saules as a popular fixture at dances who "played the violin in true plantation manner, a vigorous wielding of the bow, loud beating on the floor with his heel, accompanied with an animated action of the body..."282 According to Smith, these dances were promoted by

\footnotetext{
${ }^{279}$ McLagan and Project, A Peculiar Paradise, 11.

${ }^{280}$ Brownell, "Negroes in Oregon Before the Civil War," 30.

${ }^{281}$ Robert T Boyd, Chinookan Peoples of the Lower Columbia, 2013, 333.

${ }^{282}$ Smith, "Celebrations in Clatsop County," 40.
} 
local Columbia River bar pilots, whose ranks may have included Saules. Smith referred to the pilots as "mostly unmarried men" who were "leaders of the dancing gentry of the times.",283

What Saules likely had no way of knowing in 1845 was that Great Britain planned to occupy Cape Disappointment and install artillery near his home in preparation for a potential war with the United States. During this period, tensions increased between the two nations as neither wanted to yield possession of the Oregon Country. Furthermore, the Anglo-American Convention of 1818, which established the joint occupation of the region, contained no means by which the matter could be resolved by arbitration. ${ }^{284}$ This meant that armed conflict was probable if a diplomatic solution failed. As a precautionary measure, Sir George Simpson, the Canadian governor of the HBC, recommended that Great Britain take possession of Cape Disappointment and "erect thereon a strong battery. ${ }^{, 285}$ He claimed that ships entering the mouth of the Columbia "must pass so close under the Cape that shells might be dropped almost with certainty upon their decks from the battery." 286 Simpson was clearly willing to go to great lengths to ensure the survival of the HBC in Oregon.

On April 3, 1845, Simpson traveled to London to meet with British Prime Minister Sir Robert Peel and Foreign Secretary Lord Aberdeen to discuss how best to preserve the company's interests in the Oregon Country. Due to the growing number of American settlers and the decline of fur-bearing animals south of the Columbia River, the

\footnotetext{
283 Ibid., 39.

${ }^{284}$ Barry M. Gough, “The Royal Navy and Oregon Crisis, 1844-1846,” BC Studies: The British Columbian Quarterly 0, no. 9 (1971): 15.

${ }_{285}$ Simpson et al., "Secret Mission of Warre and Vavasour," 32.

286 Ibid.
} 
British government planned to relinquish the area from the south bank of the Columbia to the Mexican California border (42 $\left.{ }^{\circ} N^{\prime}\right) .{ }^{287}$ However, Simpson insisted that Great Britain retain the area north of the Columbia containing Fort Vancouver, Puget Sound, and the southern tip of Vancouver Island, site of the HBC's recently built Fort Victoria. Both Peel and Aberdeen dreaded the prospect of war but were confident in Great Britain's military supremacy over the United States. Two months earlier, Aberdeen sent the HMS America on a mission to the Oregon Country to "let the Americans see clearly that Her Majesty's Government are alive to their proceedings and prepared, in case of necessity, to oppose them." ${ }^{288}$ In addition to occupying Cape Disappointment, Simpson recommended that Aberdeen send four Royal Navy warships to the Oregon Country. Each ship would be stocked with a large number of marines augmented by a local army of 2000 Native and mixed-race soldiers. This was seemingly too ambitious for Peel and Aberdeen, who did not execute Simpson's plan but decided instead to send two British spies to Fort Vancouver "to gain a general knowledge of the capabilities of the Oregon territory in a military point of view, in order that we may be enabled to act immediately and with effect in defense of our rights in that quarter."289 The major objectives of this mission were to purchase Cape Disappointment, gather intelligence regarding American settlers, and investigate the practicability of sending British troops overland from Montreal to the Oregon Country. ${ }^{290}$

\footnotetext{
${ }^{287}$ Gough, "The Royal Navy and Oregon Crisis, 1844-1846," 19.

${ }^{288}$ Joseph Schafer, "Documents Relative to Warre and Vavasour's Military Reconnaissance in Oregon, 1845-6," The Quarterly of the Oregon Historical Society 10, no. 1 (March 1, 1909): 5.

289 Ibid., 16.

${ }^{290}$ Gough, "The Royal Navy and Oregon Crisis, 1844-1846," 21.
} 
In November of 1844, the British government's fears of impending conflict with the United States were fueled by the election of James K. Polk as president. Polk, a southern Democrat, was an outspoken expansionist whose platform included the annexation of Texas, the purchase of California from Mexico, and the acquisition of the entire Oregon Country extending to the southern tip of Russian Alaska $\left(54^{\circ} 40^{\prime} \mathrm{N}\right)$. While many dismissed his demands as pre-election demagoguery, Polk's demand for Oregon far exceeded any previous position of the United States and later inspired the slogan "fiftyfour forty or fight. ${ }^{, 291}$ Although the British government understood that this was merely Polk's extreme bargaining position, Prime Minister Peel was alarmed that Polk now considered setting the international boundary at the $49^{\text {th }}$ parallel as a compromise. For the British, this meant they would lose Fort Vancouver, the Puget Sound, and Fort Victoria. On the other hand, many American settlers in Oregon were delighted by the Polk's expansionist rhetoric. One in particular was Charles E. Pickett, the man who had Saules arrested and removed from the Willamette Valley. Pickett later claimed that he had a direct influence on Polk's position regarding the Oregon question. While this is difficult to prove, Pickett, who considered Polk a personal friend, did write to the president in the mid-1840s. He urged him to strike a deal with the British that would set the border at the $49^{\text {th }}$ parallel and grant the United States sole possession of Vancouver Island. ${ }^{292}$

On August 12, 1845, the two spies sent by the British government, Lieutenant Henry J. Warre and Lieutenant Martin Vavasour, arrived at Fort Vancouver. However, due to the sensitive nature of their visit, they were not allowed to divulge their true

\footnotetext{
${ }^{291}$ Johansen, Empire of the Columbia, 265.

${ }^{292}$ Powell, Philosopher Pickett, 16-17.
} 
purpose to anyone, including John McLoughlin. They instead posed as a pair of young vacationers visiting the region "for the pleasure of field sports and scientific pursuits.",293 Warre and Vavasour left Montreal on June 16 accompanied by their guide, HBC Chief Factor Peter Skene Ogden, and seven company servants. One month earlier, Ogden received instructions from Simpson to purchase Cape Disappointment upon arrival from anyone living there, provided an American settler did not already own it. The journey, which required traveling horseback across the Rocky Mountains, proved so arduous that Warre and Vavasour concluded that sending British troops overland was not feasible. They were also convinced that Fort Victoria was "ill-adapted either as a place of refuge for shipping or as a position of defence." ${ }^{294}$ Instead, they ascertained that Britain's interests were best defended by controlling the strategic waterways of the region, the Columbia River and Puget Sound. ${ }^{295}$ And once they investigated the mouth of the Columbia, Warre and Vavasour concurred with Simpson's assessment that Cape Disappointment could function as the linchpin of a regional defense. To this end, Vavasour submitted an order to his commanding officer to install three batteries of heavy guns on the Cape. ${ }^{296}$

In early September of 1845, Ogden himself traveled to Cape Disappointment to complete his instructions from Simpson to purchase the property. When he reached the desired location overlooking Baker Bay, he found Saules living there in a house. Because his mission was secret, Simpson advised Ogden not to divulge the military purpose of the

\footnotetext{
${ }^{293}$ Schafer, "Documents Relative to Warre and Vavasour's Military Reconnoissance in Oregon, 1845-6," 9.

294 Gough, "The Royal Navy and Oregon Crisis, 1844-1846," 22.

295 Simpson et al., "Secret Mission of Warre and Vavasour," 34.

${ }^{296}$ Gough, "The Royal Navy and Oregon Crisis, 1844-1846," 8.
} 
purchase and instead express a desire to establish a HBC trading post and pilot lookout on the Cape. Ogden requested that Saules sell him his house, as well as all the adjoining land. Saules apparently agreed to sell his claim for an undisclosed sum. ${ }^{297}$ Although Ogden never mentioned Saules's race in any of his correspondence, Ogden's willingness to buy the property from him suggests he might not have considered him an American. Saules also may not have represented himself as such since the HBC strongly discouraged Americans from settling north of the Columbia. ${ }^{298}$ After finalizing the sale with Saules, Ogden then traveled to Oregon City to file the purchase with the provisional government's land office. To his consternation, Ogden discovered that two American settlers, referred to as "Wheeler and McDaniell" already held a claim on the property. ${ }^{299}$ The two settlers were probably Issac Newton Wheeler and William McDaniel, both mentioned in James Nesmith diary of the Great Migration of $1843 .{ }^{300}$ While the settlers offered to sell their claim on Cape Disappointment to Ogden for \$900, Ogden refused, claiming he had "no authority vested in me to negotiate." ${ }^{301}$ In an October 1845 letter to Henry Warre, he revealed that he did not want to appear "over-anxious to obtain it, [since] we can before spring secure it at a lower rate. ${ }^{302}$

\footnotetext{
${ }^{297}$ Many historians have claimed that Ogden paid Saules $\$ 200$ for the property. While this may be true, the sum is not included in Ogden's correspondence with Warre and Vavasour. Historian T.C. Elliott probably made the first reference to this amount in 1910, although he also misidentifies Saules as "James Sanler." See T. C. Elliott, "Peter Skene Ogden, Fur Trader," The Quarterly of the Oregon Historical Society 11, no. 3 (September 1, 1910): 9.

${ }^{298}$ Howison, "Report of Lieutenant Neil M. Howison on Oregon, 1846," 20.

${ }^{299}$ Simpson et al., "Secret Mission of Warre and Vavasour," 140.

${ }^{300}$ James W. Nesmith, "Diary of the Emigration of 1843," The Quarterly of the Oregon Historical Society 7, no. 4 (December 1, 1906): 329-59.

${ }^{301}$ Simpson et al., "Secret Mission of Warre and Vavasour," 140.

302 Ibid.
} 
On November $7^{\text {th }}, 1845$, Warre received Ogden's letter and responded with an exasperated missive, reminding Ogden of Simpson's original instructions to purchase Cape Disappointment using "whatever preliminary measures you may consider it desirable should be taken. ${ }^{303}$ Ogden responded on November $16^{\text {th }}$, clarifying that he did not believe he had the authority to purchase Cape Disappointment, since his instructions forbade him to purchase it "if already possessed or occupied on behalf of the United States Government or its citizens. ${ }^{304}$ Warre countered by asking Ogden why he bought the property from Saules in the first place, whom Warre reminded him was also an American. ${ }^{305}$ This suggests that Warre and Vavasour met Saules during their reconnoitering of Cape Disappointment. Warre also questioned the legitimacy of Wheeler and McDaniel's claim: "I consider it very probable that Wheeler or McDaniell may have claims in some other part of the Territory, or even that they may have 'jumped' Mr. Saules' claim. ${ }^{306}$ On November $19^{\text {th }}$, Ogden answered Warre's question, insisting that Saules had no right to sell the property and was "merely employed in the service of Wheeler and McDaniell as a guardian to their claim on Cape Disappointment." ${ }^{, 307}$ Ogden also claimed that the two American settlers had erected a building on the land "thereby rendering their right to it still more valid. ${ }^{, 308}$ This response seemed to satisfy Warre, who concluded that neither he nor Ogden had the authority to purchase the land. However, on February 14, 1846, Ogden apparently changed his mind regarding his interpretation of

\footnotetext{
303 Ibid.

${ }^{304}$ Ibid., 141.

305 Ibid.

${ }^{306}$ Ibid., 141-142.

${ }^{307}$ Ibid., 142.

${ }^{308}$ Ibid.
} 
Simpson's instructions and purchased Cape Disappointment from Wheeler and McDaniel for $\$ 1000$, plus $\$ 200$ for surveyor's fees.

Despite Ogden's insistence that Saules never owned the property, there is evidence to suggest Warre was justified in suspecting that Wheeler and McDaniel had jumped Saules's land claim. Early settler John E. Pickernell claimed that Saules was living on a cabin overlooking Baker Bay as early as 1842, at least one year before the Great Migration of 1843 arrived. At that time, land claims were established by simple preemptions and whatever improvements the landholder made. On the other hand, it is possible that Wheeler and McDaniel staked their claim to the property while Saules was living in the Willamette Valley, since Saules, having purchased Winslow Anderson's farm, was only legally permitted to hold one land claim at a time. ${ }^{309}$ This rule was an attempt to uphold traditional republican values that favored small landholders over brazen speculators. It is also feasible that Wheeler and McDonald had actually hired Saules to protect their claim. Yet the timing of their claim is questionable. According to provisional government land claim records, Wheeler and McDaniel filed their claim on August 29, 1845, mere days before Ogden attempted to purchase the property from Saules. Furthermore, Wheeler filed four more land claims in less than a year after selling Cape Disappointment, suggesting he was more speculator than Jeffersonian yeoman. Ultimately, it is also unlikely that the provisional government's land office would have recorded the land claim of a black man in the first place, regardless of its legitimacy.

Saules was apparently not kept apprised of the situation and expressed bewilderment when informed that he was living on Ogden's claim. On May 9, 1846,

\footnotetext{
${ }^{309}$ Robbins, Landscapes of Promise, 82.
} 
Alexander Lattie, an HBC employee and noted bar pilot, received a dispatch from Fort Vancouver asking him to go to Cape Disappointment to "ascertain the mistake respecting the survey of Mr P S Ogdon's Claim." 310 The survey in question was likely the one Lattie witnessed Warre and Vavasour performing on March $1^{\text {st }}, 1846$, although Lattie does not mention the nature of the "mistake." 311 According to Lattie's May 11, 1846 diary entry, when he arrived at Baker Bay he "found a person by the name of Saul a coloured man one quarter of a mile on Mr Ogdens Claim pointed out his error and made him Sensible of mistake he had committed himself." 312 Presumably, Saules's error was not vacating the property after Ogden's purchase. This raises the question of what Ogden initially told Saules regarding their original arrangement, or whether Ogden ever actually visited Saules in the first place the previous September. On May $30^{\text {th }}, 1846$, Lattie spotted Newton Wheeler traveling near the mouth of the Columbia; it is possible Wheeler was also there to confer with Saules. ${ }^{313}$ On June $5^{\text {th }}, 1846$, Lattie reported that "Black Saul" had arrived in Fort George from Cape Disappointment "lamenting his misfortune in having to remoove off Mr Ogdens Claim after making improovements upon it." Almost exactly two years following his expulsion from the Willamette Valley, Saules was again displaced.

\section{Saules Pilots the Shark}

\footnotetext{
310 “Alexander Lattie's Fort George Journal, 1846," Oregon Historical Quarterly 64, no. 3 (September 1, 1963): 225.

${ }^{311}$ Ibid., 210-211.

${ }^{312}$ Ibid., 227.

${ }^{313}$ Ibid., 239.
} 
This was not the last time Saules found himself in the middle of the imperial struggle between the United States and Great Britain. On July $18^{\text {th }}$, the U.S.S. Shark, an American naval schooner, arrived at the mouth of the Columbia. In April 1846, Commodore John Drake Sloat had ordered the ship's captain, Lt. Neil Howison, to travel to the Oregon Country and "determine the disposition of the residents of those friendly to the United States compared to those friendly to Great Britain, and the extent, character, and tendency of emigration from the United States. ${ }^{, 314}$ Howison had earlier commanded a steamboat in Florida during the Second Seminole War and was later on the shortlist to serve on the U.S. Ex. Ex. before Lt. Charles Wilkes's appointment. Sloat also instructed Howison to "cheer our citizens in that region by the presence of the American flag" and assure them that a favorable agreement with Great Britain was imminent. ${ }^{315}$ The Navy also sent the Shark to Oregon to offset the presence of the HMS Modeste, a much larger British warship anchored at Fort Vancouver. However, before Howison could fulfill his duties, he had to first cross the Columbia bar. Howison planned on using the maps prepared by Wilkes of the U.S. Ex. Ex. but soon realized that the sands of the bar had shifted dramatically since Wilkes had first surveyed the region in 1841. Howison's trepidation was increased when a crewmember informed him that he had been aboard the U.S.S. Peacock exactly five years earlier to the day when it was wrecked at the bar.

Because the Shark carried no pilot with local experience, Howison had his crew fire their guns to summon a bar pilot. When none came, Howison then rounded Cape Disappointment. Once the ship approached Baker Bay, a boat came alongside the Shark

\footnotetext{
${ }^{314}$ Gregory Paynter Shine, “'A Gallant Little Schooner': The U.S. Schooner Shark and the Oregon Country, 1846," Oregon Historical Quarterly 109, no. 4 (December 1, 2008): 546, doi:10.2307/20615903. ${ }^{315}$ Ibid., 547.
} 
containing William Gray, Asa Lovejoy, and Reverend Henry Spalding. Gray was an Oregon politician, former Presbyterian missionary, and author of an early history of Oregon. Lovejoy was the mayor of Oregon City and co-founder of Portland. Spalding was a Presbyterian missionary who first traveled overland to the region with his wife, Eliza, Gray, and fellow missionaries Marcus and Narcissa Whitman. This esteemed trio informed Howison that "no regular pilots were to be had for the river, but that there was a black man on shore who had been living many years at the cape, was a sailor, and said, if sent for he would come off and pilot us up to Astoria." 316 The man was Saules, who still lived in the Cape Disappointment area despite his expulsion from Ogden's claim.

According to Howison, once Saules was on board the Shark, he "spoke confidently of his knowledge of the channel" and "had been living here for the last six [years]." 317 Howison does not mention whether Saules informed him that he, too, was on board the Peacock when it suffered a total loss. Saules then "ordered the helm put up, head sheets aft, and yards brace" with an air of confidence that convinced Howison "that he was fully competent to conduct the vessel." ${ }^{, 318}$ Howison then handed over command of the Shark to Saules. Unfortunately, after twenty minutes, Saules ran the ship ashore on Chinook shoal. The ship remained there for several hours, where it took a severe beating from the current without suffering any damage. Later that evening, the ship broke free from the shoal and Howison had it anchored in the channel until the following morning. In his fanciful piece about Saules for the Overland Monthly, Charles Melville Scammon suggested that Saules was then thrown overboard, although Howison never mentions how Saules was treated

\footnotetext{
${ }^{316}$ Howison, "Report of Lieutenant Neil M. Howison on Oregon, 1846," 5.

${ }^{317}$ Ibid.

${ }^{318}$ Ibid.
} 
immediately after the accident. ${ }^{319}$ According to Howison, the three settlers, Gray, Lovejoy, and Spalding, had witnessed the entire incident and "feeling themselves somewhat responsible for the employment of this pretended pilot," went to Astoria to obtain the services of HBC bar pilot Alexander Lattie. Lattie and Old George, the Native pilot who had helped to rescue the crew of the Peacock five years earlier, then successfully brought the Shark to Fort Vancouver.

Saules failure to pilot the Shark became one of the events for which he is best known. And like the Cockstock Affair and the Saules-Pickett dispute, the incident was preserved for posterity in a report presented to the U.S. Congress. In addition, on August 6, 1846, the Oregon Spectator reported that "the Shark was run aground upon Chenook shoal, through the unskillfulness of a negro man living at the Cape, who undertook to pilot her over to Astoria." ${ }^{320}$ The mishap is also mentioned in Hubert Howe Bancroft's History of Oregon. Howison's report blamed Saules's incompetence as a bar pilot for the near disaster, and many historians writing about episode have echoed this assessment. For instance, in his article on the U.S.S. Shark, Gregory Paynter Shine refers to Saules as a “self-proclaimed bar-pilot" who "hoodwinked Howison into engaging his services.",321 Shine fails to mention that Saules was recommended by three of the most prominent and respected settlers in the region. William Gray, in particular, lived in Oregon City at the time of the Cockstock Affair and Saules-Pickett dispute, and in 1845 moved to Clatsop Plains where Saules was well known. And Lattie, the pilot who took over for Saules, made no reference to Saules's presumed incompetence. Instead, he claimed the Shark

\footnotetext{
319 Scammon, "Pioneer Nig Saul," 275.

320 “The U.S. Schooner Shark," Oregon Spectator, August 6, 1846, 2.

${ }^{321}$ Shine, "A Gallant Little Schooner," 21.
} 
"took onboard Saul a coloured man as Pilot, who unluckly got the vessel on shore behind the west end of Chinook Spit." ${ }^{, 322}$ Furthermore, Astoria historian Roger T. Tetlow suggested that Saules was likely more familiar with the shallow draft of the flat-bottomed scows more commonly found on the Columbia River, as opposed to the deeper keel of the Shark. ${ }^{323}$ The Shark also had design quirks of which Saules was probably unaware. According to Shine, "Another cost of the extensive rig (masts, spars, and sails) and heavily laden foremast was the ship's inclination to lower its bow and dive under when pressed by the wind under full sail."324 Therefore, while Saules was not as experienced a bar pilot as either Chinook George or Alexander Lattie, he was also facing one of the world's most difficult rivers to navigate in an unfamiliar vessel. ${ }^{325}$

Howison also had ample reason to shift blame in his report to Congress, since his mission ultimately ended in disaster. After arriving in Fort Vancouver, Howison received a typically warm reception from the recently retired John McLoughlin, as well as Chief Factors James Douglas and Peter Skene Ogden. This was despite Howison's oral reassurance to American settlers that the United States would never accept any boundary settlement south of the $49^{\text {th }}$ parallel. Howison and his crew also experienced cordial relations with the crew of the Modeste, with whom they often drank and dined. ${ }^{326}$ On August 23, 1846, the Shark departed from Fort Vancouver, again without a bar pilot since both Lattie and Chinook George were unavailable. On September $8^{\text {th, }}$ after two weeks of

\footnotetext{
322 "Alexander Lattie's Fort George Journal, 1846," 49.

${ }^{323}$ Roger T. Tetlow, "Black Saul Details," Daily Astorian, March 12, 1975.

${ }^{324}$ Shine, "A Gallant Little Schooner," 538.

${ }^{325}$ Chinook George, a prominent bar pilot and interpreter, also helped rescue the crew members of the U.S.S. Peacock. He is sometimes referred to as Indian George, One-eyed George, and George Ramsay. See J. Neilson Barry, "Astorians Who Became Permanent Settlers," The Washington Historical Quarterly 24, no. 3 (July 1, 1933): 300.

${ }^{326}$ Shine, "A Gallant Little Schooner," 549-550.
} 
river travel, an impatient Howison attempted to cross the bar himself, having received strict orders to depart by September $1^{\text {st }} \cdot{ }^{327}$ However, the Shark struck the bar and took heavy damage from the churning sea. Howison was able to get all twenty-four crewmembers safely to the Clatsop Beach, but the Shark was completely destroyed. Ironically, the shivering crew warmed themselves with a fire built from planks salvaged from the wreck of the Peacock. ${ }^{328}$ Despite Howison's haste in crossing the bar without a pilot, Congress absolved him of any wrongdoing. Unfortunately, it is not known what Saules thought of the wreck of the Shark, although he likely witnessed it from his residence on Cape Disappointment.

\section{Life on the Columbia}

During the period, Saules worked aboard the Calapooia, a 35-ton schooner that carried passengers and cargo throughout the region. The vessel was also often used to bring newly arrived settlers from the foot of the Columbia River rapids near the Cascade Mountains to Oregon City. The Calapooia was built in the August of 1844 by Aaron Cook, a British settler with pro-American views, and was based in Oregon City. ${ }^{329}$ In May 1846, Cook placed an advertisement in the Oregon Spectator which announced that the ship was for sale. ${ }^{330}$ At some point, Brazil Grounds, a prominent figure in the early maritime history of the region, purchased the vessel and may have hired Saules as a

\footnotetext{
${ }^{327}$ Ibid., 555.

${ }^{328}$ Ibid., 557.

${ }^{329}$ Oregon Pioneer Association Reunion, Transactions of the Annual Reunion of the Oregon Pioneer Association, 1876, 12.

${ }^{330}$ Oregon Spectator, May 28, 1846.
} 
crewmember. ${ }^{331}$ Grounds had recently arrived overland from Illinois and may have had more tolerant racial views than most early settlers, as he later built a schooner dubbed the Black Republican. ${ }^{332}$

In late 1846, Saules again found himself in the Willamette Valley facing serious criminal charges. The December 24, 1846 edition of the Oregon Spectator featured the following item:

A negro man named James D. Saul was brought to [Oregon City] recently from the mouth of the river, charged with having caused the death of his wife, an Indian woman. He was examined before Justice Hood, the result of which examination we have never been able to ascertain, but the accused is at large and likely to remain so, we suppose. ${ }^{333}$

Andrew Hood was the justice, a native of Ireland who traveled overland to Oregon City in $1845 .^{334}$ However, little else is known about this case, including who brought Saules to Oregon City or who pressed charges. It is also not known whether the case was dropped due to lack of evidence or if the life of a Native woman was not considered important enough to pursue charges.

The 1897 diary of Silas B. Smith does not provide any additional information on the aforementioned case, but Smith recalled witnessing Saules receiving corporal punishment for an unnamed crime. According to Smith, "After a while, Saul got into bad ways and the settlers decided that he should be given a public flogging." 335 The settlers then tied Saules to a tree and whipped him with the end of a rawhide lariat. Smith, who

\footnotetext{
${ }^{331}$ Wright, Lewis \& Dryden's Marine History of the Pacific Northwest, 21.

${ }^{332}$ Ibid., n. 21. The Black Republican is also the name of a type of cherry first grown in 1860 by Seth Lewelling, an abolitionist Quaker who lived in the Willamette Valley. See The Oregon Grower (Oregon Growers Co-operative Association, 1921), 97.

${ }^{333}$ Oregon Spectator, December 24, 1846.

${ }^{334}$ Ichabod Sargent Bartlett, History of Wyoming (S. J. Clarke Publishing Company, 1918), 348.

335 Smith, "Celebrations in Clatsop County," 40.
} 
was a young child at the time, gives a chillingly vivid account: "From the first blow, he gave agonized shrieks and frantically tore and struggled at his fastenings and piteously begged them to desist. He continued his screams all through the whipping." 336 Smith claimed that because of Saules's public disgrace, “troubles affected his mind and he became partially insane." ${ }^{337}$ Smith places the onset of Saules's mental problems to early 1848, although he does not offer a date for the public whipping. Despite the anti-black "Lash Law" of 1844, Smith insisted that such punishments were very rare in Clatsop County and that settlers only flogged one other man during this period. The other victim, also non-white, was a Coos Bay Native who allegedly stole a tool from an American settler and then threatened him with a knife when the settler tried to retrieve it. Smith, whose mother was a Clatsop, contrasted the two whippings to demonstrate that, unlike Saules, the Native "displayed the traditional stoicism of his race" as a means of denying his enemies any evidence of weakness. ${ }^{338}$

By 1848, Saules apparently often commanded the Calapooia by himself. This is probably because its owner, Captain Brazil Grounds, moved to San Francisco that same year. ${ }^{339}$ Samuel McKean was an early settler who described meeting Saules aboard the craft. According to his diary, McKean was seven years old when he arrived with his family in Oregon from Illinois in 1847. The family settled in Linnton, a few miles west of Portland. In 1848, John McClure encouraged McKean's father to move to Astoria, where McClure had established a land claim. In September 1848, the family and their

\footnotetext{
336 Ibid.

337 Ibid.

${ }^{338}$ Ibid., 40-41.

${ }^{339}$ Wright, Lewis \& Dryden's Marine History of the Pacific Northwest, n. 21.
} 
belongings traveled aboard the Calapooia, which McKean described as "a queer kind of craft...built like a scow and rigged as a schooner." "340 According to McKean, "She was commanded by a man of the African persuasion called 'Nigger Sol,' an odd character who felt the dignity of this position as captain of so fine a craft." ${ }^{, 34}$ McKean added that Saules was "good natured, however, and we got along very well. ${ }^{342}$ The voyage took eight days, as difficult river conditions often required Saules to either anchor the craft or tie it to the banks while the tide was flooding. ${ }^{343}$ Saules's anchor was apparently unusual for the time and combined the crotch of a tree, an oblong stone, and the root of a sapling. ${ }^{344}$ Charles Melville Scammon claimed that Saules later survived the sinking of the Calapooia near Astoria, although he does not provide a date. This story is somewhat corroborated by the fact that, in 1975, an Astoria fisherman snagged a strange looking object in his gillnet that matched the description of Saules's anchor. ${ }^{345}$

\section{An Americanized Oregon and the 1849 Black Exclusion Law}

On June $16^{\text {th }}, 1846$, Warre sent a letter to Ogden informing him that Simpson approved the purchase of Cape Disappointment. Yet such machinations were for naught, as at the same time Ogden and Warre were fretting over the particulars of the land deal, Great Britain and United States were negotiating over the location of the Oregon border.

\footnotetext{
${ }^{340}$ McKean, "Memoirs of Samuel T. McKean," 6.

${ }^{341}$ Ibid., 6-7.

342 Ibid., 7.

${ }^{343}$ Ibid. While McKean's claim that he trip took eight days seems like a misprint, Columbia River travel was arduous during the mid-nineteenth century. For instance, the first journey of the Calapooia took four days to travel from Oregon City to Astoria in August of 1845. See Reunion, Transactions of the Annual Reunion of the Oregon Pioneer Association, 12.

344 Scammon, "Pioneer Nig Saul," 274.

345 Tetlow, "Black Saul Details."
} 
On June $18^{\text {th }}$, 1846 , two days after Ogden received Warre's final letter regarding the purchase, the U.S. Congress ratified the Oregon Treaty, establishing the international border at the $49^{\text {th }}$ parallel, while granting Great Britain sole possession of Vancouver Island. While this agreement meant that Great Britain lost both Puget Sound and access to the lower Columbia, the British government's desire to preserve their Oregon holdings was tempered by severe domestic problems. These included a failed potato crop in Ireland, a below-average grain harvest in England, and unrest over the repeal of Britain's "corn laws." The United States, on the other hand, pulled back from its bellicose insistence on $54^{\circ} 40^{\prime} \mathrm{N}$, since the government was preoccupied by tensions with Mexico that erupted into full-scale war in May $1846 .{ }^{346}$ All of this occurred unbeknownst to anyone living in the Pacific Northwest, as news of the treaty did not reach Oregon until late October 1846.

Although by 1847 Saules seemed to have regained much of his mobility and visibility in the region, this would prove temporary. Developments during the year challenged the notion that Oregon could continue to exist as a heterogeneous middle ground in which mutual interests superseded military force. Yet as is often the case with settler colonialism, it was not the U.S. government that initiated this shift but rather the inhabitants of the region themselves. Richard White describes this peculiar brand of American imperialism as "a world system in which minor agents, allies, and even subjects at the periphery often guide the course of empires." 347 This was particularly true

\footnotetext{
${ }^{346}$ Morrison, Outpost, 440.

${ }^{347}$ White, The Middle Ground, xi.
} 
when regional tensions exploded into violence several hundred miles upriver from Cape Disappointment on the Columbia Plateau.

On November 29, 1847, a small group of Cayuse and Umatilla men killed Marcus and Narcissa Whitman, as well as twelve other settlers, at the Whitman's house at the Waiilatpu Mission. While the assailants believed Marcus Whitman had intentionally infected Cayuses with deadly diseases, the incident sent shockwaves throughout the region and sparked a series of wars with the Native groups of the region. These conflicts often followed a pattern of Native attacks met with severe retribution from American settlers and the military. These attacks were largely a reaction to the various pressures American settlement placed on Native communities, such as the extinguishment of Native title to land, enclosure of hunting and gathering grounds, and the imposition of exogenous laws and values. In May of 1848, Sheriff Joseph Meek, the man who once brought Saules before a county judge for allegedly inciting Native people to violence, traveled to Washington D.C. to bring news of the Waiilatpu tragedy and convince President Polk that the residents of the Oregon Country needed the protection of the U.S. military. On August 1848, Polk signed the Oregon Territorial Act, which established Oregon as the first territorial government west of the Rocky Mountains. By the following year, the U.S. Army established bases at the two sites previously occupied by the HBC, Fort Vancouver and Fort Nisqually.

The aftermath of the Whitman Incident not only ended much of Oregon's political isolation from the United States, it also, seemingly inexplicably, inspired a renewed outcry against allowing black people to reside in the territory. Like the provisional 
government before it, the territorial government promoted the vision of Oregon as an ethnically homogenous region dominated by Anglo-Protestant farm families. Many white residents continued to see the presence of non-whites as a threat to their growing community and would again utilize the state apparatus to attempt to regulate the racial composition of the region. Applying military force on recalcitrant indigenous populations was one way to accomplish this. Another was the resurrection of a black exclusion law. While Oregon continued the previous ban on slavery, several politicians wanted to ensure that black people did not feel welcome in the new territory. On September 26, 1849, the territorial House of Representatives, with a vote of twelve to four, passed a bill "to prevent Negroes and Mulattoes from coming to, or residing in Oregon." ${ }^{348}$ Yet the drive to exclude blacks was never unanimous and some members of the legislature, such as council member Wilson Blain, bitterly objected to the law. ${ }^{349}$ The new law prohibited free black or mulatto people from immigrating to Oregon, although it allowed black or mulatto settlers already living in the territory, like Saules, to remain. Unlike the earlier black exclusion law, the 1849 did not specify punishment for those who refused to leave and instead left it to the discretion of individual judges.

There is little information on the background of the new law, although Samuel Thurston, Oregon's territorial delegate to the U.S. House of Representatives, defended it before Congress in 1850. According to the Oregon Spectator, when Ohio Whig Congressman Joshua Reed Giddings voiced his objections to the bill, Thurston countered

\footnotetext{
348 Statutes of a General Nature Passed by the Legislative Assembly of the Territory of Oregon: At the Second Session, Begun and Held at Oregon City, December 2, 1850. In the Seventy-Fifth Year of the Independence of the United States (Asahel Bush, Territorial Printer, 1851), 182.

${ }^{349}$ Nokes, Breaking Chains, 54.
} 
by insisting "the people of Oregon were not pro-slavery men, nor were they pro-negro men; there were but few negroes in the territory and [we] hoped there never would be more." 350 Thurston contended that "the people themselves excluded [blacks]" and he "trusted that Congress would not introduce them in violation of their wishes." 351 While it was somewhat disingenuous for Thurston to claim the "the people" had approved the law, since it was not decided by popular vote, he was correct about the small number of black people living in Oregon. According to the 1850 census, Oregon contained 13,294 people, but census takers counted only 54 they considered "Negroes.",352

While he was never mentioned by name, it is likely that Saules influenced the language of the 1849 black exclusion bill. For example, the preamble dredged up old fears about black-Native collaboration: "Whereas, situated as the people of Oregon are, in the midst of an Indian population, it would be highly dangerous to allow free negroes and mulattoes to reside in the Territory, or to intermix with the Indians, instilling into their minds feelings of hostility against the white race." ${ }^{353}$ This could be an indirect reference to the Second Seminole War of the previous decade or even the long-running anxieties heightened by the Whitman Incident two years earlier. However, that particular event did not involve any black people. On the other hand, the specific wording is far more suggestive of the Saules-Pickett dispute of 1844. Saules was a black man with marital and familial ties to the local indigenous population. Saules had also once allegedly joined

\footnotetext{
350 “Oregon," Oregon Spectator, August 22, 1850, 1.

351 Ibid.

${ }^{352}$ McLagan and Project, A Peculiar Paradise, 185.

${ }^{353}$ Statutes of a General Nature Passed by the Legislative Assembly of the Territory of Oregon, 182.
} 
forces with Native people to defend their rights against a white settler. Furthermore, no other incident involving this sort of racial alliance ever took place in the region.

The preamble also implies that, due to Anglo-American encroachment, Native people had ample reasons for hostility, which rebellious black men could then trigger. And applying the racialist logic of many white settlers, blacks and Native people had a natural affinity for one another due to their lowly positions on the racial hierarchy. And the use of the term "intermix" connotes interracial sexual activity, which was one of the hallmarks of the middle ground. This also suggests that a prohibition on interracial relations would be necessary to preserve order in the new settler colonial society. Even Jesse Applegate, a settler who believed in the fair treatment of ethnic minorities, wrote of free blacks in 1865, "But it is not among the rights he is entitled to that his sons shall marry our daughters, or that our sons shall marry his; a power higher than man's has forbidden such connection..."354 According to Gray Whaley, Oregon legislators believed "the supposedly inferior, savage races would naturally combine and form a sort of SuperRogue and deny American citizens ('whites') the security of their birthright., ${ }^{, 355}$ Yet even in the nineteenth century, many found this logic dubious. In 1886, historian Frances Fuller Victor wrote that fears of black-Native collaboration "could not be advanced as a sufficient explanation...to keep negroes out of the territory, because all the southern and western frontier states had possessed a large population of blacks, both slave and free, at the time they had fought the savages, without finding the negroes a dangerous element of

\footnotetext{
${ }^{354}$ Schafer, "Jesse Applegate," 232.

${ }^{355}$ Gray H. Whaley, "Oregon, Illahee, and the Empire Republic: A Case Study of American Colonialism, 1843-1858," The Western Historical Quarterly 36, no. 2 (July 1, 2005): 176, doi:10.2307/25443145.
} 
their population." ${ }^{356}$ Victor, however, fails to consider the Second Seminole War, which involved Native and black soldiers fighting against the U.S. Army on the southern frontier.

Even more remarkable is that the bulk of the exclusion law addresses the behavior of black sailors arriving on ships, especially potential deserters, of which Saules was likely the most visible in Oregon during this period. And since black sailors continued to comprise a sizeable portion of most sea crews, territorial legislators seemingly viewed them a particular threat. Section two of the law allowed masters and owners of ships to bring blacks to Oregon but also made them responsible for the actions of their black

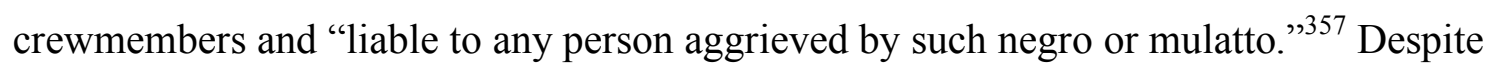
fears of what black sailors like Saules might do if left unattended, this provision reveals that legislators recognized that maritime commerce was necessary to the economic health of the region. Therefore, they were pragmatic about the need for ships to come to Oregon. Section three stipulated that blacks and mulatto sailors must not leave the immediate vicinity of their vessels unless accompanied by their vessel's master, while section four required that the master must remove all black or mulatto crewmembers from the territory within forty days. ${ }^{358}$ These measures were obviously intended to prevent black sailors from deserting their ships and establishing residency in Oregon, something Saules had done in 1841. Finally, section five stated that if the master or owner of a ship failed to abide by the previous sections, a territorial court would have them indicted, imprisoned

\footnotetext{
${ }^{356}$ Bancroft and Victor, History of Oregon ..., 1888, 157.

${ }^{357}$ Oregon, Statutes of a General Nature Passed by the Legislative Assembly of the Territory of Oregon, 181.

358 Ibid.
} 
and fined. ${ }^{359}$ This was a bold move, as legislators were willing to risk the possibility that some ships might bypass Oregon altogether due to the severity of the law.

Oregon's receptiveness to black exclusion was somewhat unique in the Far West. For example, in 1849, the same year Oregon passed its territorial black law, California rejected a similar black exclusion law. That year, at the height of the Gold Rush, California voters elected Peter Burnett, the architect of Oregon's original "lash law," as the state's first governor. Burnett immediately urged the California legislature to ban black immigration, warning that the lure of gold "would bring swarms of [black people] to our shores." ${ }^{360}$ Burnett's word choice is interesting in light of the Oregon law's emphasis on black sailors, as he assumes black people would arrive on ships as opposed to overland. Burnett contended that arrival of black settlers would only add to an already "heterogeneous mass of human beings, of every language and of every hue.",361 California's legislature, which was dominated by Whigs, rejected Burnett's proposal, denouncing it as "unduly influenced by prejudice and behampered by fear and favor."362 R.G. Gilbert, the Whig editor of the Alta, a California newspaper, believed free black men should have the opportunity to improve their economic position in the state, but also doubted that enough blacks would migrate to California to significantly alter the racial composition of the state. ${ }^{363}$ Yet black people would not experience anything resembling legal equality in the new state and, despite the absence of an exclusion law, as

\footnotetext{
${ }^{359}$ Ibid., 182.

${ }^{360}$ Berwanger, The Frontier against Slavery, $70-71$.

${ }^{361}$ Ibid., 71.

${ }^{362}$ Ibid.

${ }^{363}$ Ibid.
} 
California's first state constitution forbade black people from voting or serving in the militia. $^{364}$

\section{The 1850 Donation Land Act}

Although the 1849 exclusion law boldly declared Oregon a white man's territory, the 1850 Donation Land Act was arguably more instrumental in establishing a racial status quo by encouraging the Anglo-American resettlement of the region. The law was largely written by Oregon territorial delegate Samuel R. Thurston as a response to the original Oregon Territorial Act, which did nothing to honor land claims recorded by the provisional government's land office. To add to this insult, the U.S. government had initially granted 640 acres to each missionary station in the new territory. ${ }^{365}$ The Donation Land Act, which President Millard Fillmore signed into law on September 27, 1850 , not only validated the legal title of land claimed by early overlanders, it also granted 320 acres of free land to male American citizens, provided they lived on it and improved it through cultivation. If the male settler was married, his wife was granted an additional 320 acres, thus encouraging families to settle in the male-dominated region. ${ }^{366}$ Passage of the five-year act resulted in eight thousand Anglo-American claimants receiving three million acres of land from 1850 to 1855 , as well as a population increase of 300 percent. $^{367}$ This also meant that the number of white settlers now exceeded the

\footnotetext{
${ }^{364}$ Ibid., 65.

${ }^{365}$ Bancroft and Victor, History of Oregon, Volume 2, 261.

${ }^{366}$ This number was halved for married couples arriving after 1850 , who received 320 acres in total. See Robbins, Oregon, 49.

367 Schwantes, The Pacific Northwest, 121.
} 
entire Native population of the region, thoroughly upsetting the delicate balance that had characterized the region for much of the nineteenth century. ${ }^{368}$

The Donation Land Act was also a decisive victory over the last vestiges of the middle ground forged by indigenous peoples and the fur trade. The act was intended to usurp land claims made prior to the formation of the provisional government, particularly those of non-Americans associated with the fur trade. Thurston, in advocating for the act in Congress, insisted on the phrase "American citizen" in the law itself, a designation he contrasted with "every servant of the Hudson's Bay Company." "369 For instance, section eleven stipulated that the territorial legislature would receive the majority of John McLoughlin's Oregon City land claim. According to Thurston during a congressional debate on May 28, 1850, "[The $\mathrm{HBC}]$ has been warring against our government these forty years." ${ }^{, 370}$ This recalls the earlier unfounded belief among some American settlers that the HBC was arming local Native people to undermine their nascent community. Thurston also singled out one culprit in particular: "Dr. McLoughlin has been their chief fugleman, first to cheat our government out of the whole country, and next to prevent its settlement."371

Saules, like most non-white residents of Oregon, was unable to take advantage of this free land bonanza, and the Donation Land Act was, in many ways, a more effective racial exclusion act than either the 1844 or 1849 black exclusion laws. The law had an enormous impact on regional power dynamics and the racial composition of Oregon. In

\footnotetext{
${ }^{368}$ Elliott West, The Last Indian War: The Nez Perce Story, 1st ed. (Oxford University Press, USA, 2011), 60.

369 Statutes of a General Nature Passed by the Legislative Assembly of the Territory of Oregon, 52.

${ }^{370}$ Bancroft and Victor, History of Oregon ..., 1888, 120.

${ }^{371}$ Ibid.
} 
the nineteenth century American West, wealth and power was measured by land ownership, yet only males with white fathers and their white wives qualified for free land according to the law. In drafting the initial draft of the bill, Thurston was therefore conflating whiteness with legitimate American citizenship. This notion had its origins in the 1790 Naturalization Act, which limited American citizenship to whites. The act's exclusionary provisions therefore racialized Oregon land claims as both American and white spaces. Those forbidden from owning land in Oregon included blacks, Natives without white fathers, Chinese, and Pacific Islanders. Thurston's justification for excluding Pacific Islanders was partially due to their prominent role as Oregon fur industry workers, yet it also revealed that he, like so many racialists of the nineteenth century, held a binary view of race based more on skin tone than specific ethnicity. On May 28, 1850, when defending the racial exclusion clause before the U.S. House of Representatives, Thurston referred to "Canakers" or Pacific Islanders as "a race of men as black as your negroes of the South, and a race, too, that we do not desire to settle in Oregon.. ${ }^{372}$

The Donation Land Act was also significant in that it allowed some women, namely the wives of claimants, to own large parcels of land. This was one means to address Oregon's imbalanced sex ratio: in the 1850 census, white women only comprised 37.8 percent of the 13,294 people counted. ${ }^{373}$ Yet the granting of land claims to the wives, and eventually widows, of white male settlers was also a means to encourage the

\footnotetext{
${ }^{372}$ Whaley, Oregon and the Collapse of Illahee, 176.

373 "Center for the Study of the Pacific Northwest," accessed February 17, 2014, https://www.washington.edu/uwired/outreach/cspn/Website/Classroom\%20Materials/Pacific\%20Northwest \%20History/Lessons/Lesson\%209/Census\%20Data.html.
} 
racial and ethic homogenization of the region, as well as to further the othering of nonwhites. In 1850, thousands of women living in Oregon could not qualify for land, as they were married to either Native, Pacific Islander, Chinese, black, British, or FrenchCanadian men. The exclusionary aspects of the Donation Land Act further marginalized these women by elevating the position of white women in the region. These white women would presumably also give birth to the next generation of white residents. Margaret D. Jacobs argues that the mobilization of white women is a necessary component of settler colonialism. For Jacobs, the inclusion of white women in settler colonialist projects encourages settlement by white families, balances sex ratios, reproduces colonial gender systems, and makes "the home" a "means of establishing dominance in the new settlement." 374 The increasing number of white women in the Pacific Northwest also allowed promoters of racial exclusion to exploit fears that non-whites in the region would pose a sexual threat to the white wives and daughters of settlers. ${ }^{375}$

Saules also possibly had an impact on the rhetoric used to defend the bill in Congress. When faced with a possible amendment to remove various exclusionary aspects from the bill, Thurston continued to raise the familiar specter of black-Indian collaboration. This suggests the lingering influence of both the Saules-Pickett dispute and the Second Seminole War. For instance, during the May 28, 1850 congressional session, Thurston softened his stance towards British and French-Canadians living in Oregon; he consented to include them in the land law if they were willing to become American

\footnotetext{
${ }^{374}$ Margaret D. Jacobs, White Mother to a Dark Race: Settler Colonialism, Maternalism, and the Removal of Indigenous Children in the American West and Australia, 1880-1940 (University of Nebraska Press, 2011), 22.

${ }^{375}$ Ibid.
} 
citizens. At the same time, Thurston reaffirmed his rigid stance against non-whites: "I am not for giving land to Sandwich Islanders or negroes." He went on to claim that "the Canakers and negroes, if allowed to come there, will commingle with our Indians, a mixed race will ensue, and the result will be wars and bloodshed in Oregon."376 The proposed bill did make an exception for "American half breeds," which was probably due to the fact that many prominent American male settlers had Native wives and wanted their progeny to also receive land. ${ }^{377}$ As for full-blood Native people, Thurston successfully lobbied Congress to authorize the president to appoint commissioners that would negotiate treaties with Native groups "for the extinguishment of their claims to lands lying west of the Cascade Mountains." ${ }^{378}$ This was the first stage in a process that later resulted in the removal of several Native groups from their ancestral lands.

The Donation Land Act was an also an example of settler colonists driving U.S. policy, rather than the reverse. Despite the expansionist rhetoric of President Polk and Missouri Senator Thomas Hart Benton, in the 1840s Manifest Destiny remained a contentious topic among U.S. politicians, especially when combined with the question of whether slavery would extend to the Far West. Yet many Oregonians believed the federal government had tacitly promised settlers free land in West, even though Senator Lewis Linn's Oregon Territorial Bill, a precursor to the Donation Land Act, failed to pass the U.S. House of Representatives in 1843. In 1849, when the Oregon legislature appointed Thurston as its delegate to Congress, his first and most important assignment was to draft

\footnotetext{
${ }^{376}$ Whaley, Oregon and the Collapse of Illahee, 176.

${ }^{377}$ Bancroft and Victor, History of Oregon ..., 1888, 120.

${ }^{378}$ William Wharton Lester, Decisions of the Interior Department in Public Land Cases: And Land Laws Passed by the Congress of the United States: Together with the Regulations of the General Land Office (H. P. \& R. H. Small, 1860), 156.
} 
a new land bill and take it to Washington D.C. In a remarkable case of the periphery guiding the empire, the resulting Donation Land Act was virtually identical to Thurston's proposed bill. ${ }^{379}$ Historian Elliott West describes the post-Civil War resettlement and Americanization of the West as part of a "Greater Reconstruction" in which "a centralized authority was extended and given form—states and territories, reservations and a bureaucracy to control native people. ${ }^{, 380}$ Yet this process began decades earlier and was far from unidirectional - it involved Oregon politicians and their constituents placing pressure on the federal government to help enact their own particular vision of a culturally and ethnically homogenous West.

On September 27, 1850, Saules's original plot of land on Cape Disappointment became a donation land claim. The recipient was none other than Elijah White, the former Indian agent who had contributed to regional tensions by imposing foreign laws on Native groups. White had also convinced Saules to leave the Willamette Valley and later urged the provisional government to remove all black people from the region. White, who moved back to Ithaca, New York in 1845, returned to Oregon in 1849 to refashion Cape Disappointment into Pacific City, a town he hoped would eclipse both Oregon City and San Francisco in importance. ${ }^{381}$ In 1850, White and his business partner, James D. Holman, subdivided the property and erected a hotel and sawmill. However, on February 26, 1852, White's ambitions were dashed when President Fillmore, citing the fourteenth section of the Donation Land Act, ordered that Pacific City be turned over to

\footnotetext{
${ }^{379}$ Robbins, Landscapes of Promise, 83.

${ }^{380}$ West, The Last Indian War, xxi.

${ }^{381}$ Mildred Colbert, "Naming and Early Settlement of Ilwaco, Washington," Oregon Historical Quarterly 47, no. 2 (June 1, 1946): 182.
} 
the federal government and converted into a military reservation later known as Fort Canby. ${ }^{382}$ While White was compensated for the land, this demonstrated how bringing the federal government into the region for protection could have unforeseen consequences.

The Donation Land Act was also the culmination of a colonial project that began when Saules, Lt. Charles Wilkes, and the rest of the U.S. Ex. Ex. arrived on the lower Columbia in the summer of 1841 . As he surveyed the region, Wilkes was confident that it would one day belong solely to the United States. He employed the era's most advanced surveying and cartographic techniques to create accurate yet abstract representations of physical space that could be then presented to politicians in Washington D.C. For those who sought to absorb the Pacific Northwest into United States, these images seemed to reinforce and legitimate their imperial desires. Geographer Daniel Clayton argues that the appropriation of territory by the nation-state is often "underpinned by imperial intentions that were at once public and scientific." 383 The Donation Land Act also used surveys and cartography to apply a gloss of scientific objectivity to the colonial project of seizing and privatizing land once held in common. Unlike the more primitive techniques of the provisional land office, the Donation Land Act brought a surveyor general to the area in 1851. He implemented a formal survey that converted what the federal government called the "unsurveyed public domain" into square-shaped private land plots easily

\footnotetext{
${ }^{382}$ U.S. Congress, House, Index to the Reports of Committees of the House of Representatives for the First and Second of the Forty-Fifth Congress 1877-1878, 45 ${ }^{\text {th }}$ Cong., 2d Sess., 1878, 176.

${ }^{383}$ D. Clayton, "The Creation of Imperial Space in the Pacific Northwest," Journal of Historical Geography 26, no. 3 (July 1, 2000): 341.
} 
identified and referenced on official maps. ${ }^{384}$ According to historian Katherine G. Morrissey, "Representing land as state-regulated property, accessible for private individual ownership, a commodity to be bought and sold on the market, the maps connected their users to national, economic, legal, and political systems." ${ }^{, 385}$ This system therefore reified land itself as political space fit only for those whose race qualified them for citizenship.

\section{The Death of Saules}

Perhaps it is only a coincidence, but Saules virtually disappears from the historical record following the passage of the 1849 black exclusion law and the 1850 Donation Land Act. This is in stark contrast with the previous nine years, in which Saules was regularly featured in government reports, settler diaries, and newspaper articles. It is possible that with Oregon's dramatic population growth in the late 1840s and early 1850s, Saules's presence was less noticeable in the region. On the other hand, if the aforementioned racist legislation is any indication of how white Oregonians treated nonwhites, Saules probably did not feel welcome anywhere near the Willamette Valley. Throughout the nineteenth century, many black people in the region preferred to remain on the north side of the Columbia River. There is some evidence that Saules may have lived north of the Columbia in the vicinity of Cathlamet. In 1851, Saules's name was on the ledgers of the Cathlamet general store. Two years later, the store still listed him as an outstanding debtor. The 2007 Oregon Boating Guide, published by the Oregon State

\footnotetext{
${ }^{384}$ Whaley, Oregon and the Collapse of Illahee, 162, 187.

${ }^{385}$ Katherine G. Morrissey, Mental Territories: Mapping the Inland Empire, First Edition (Cornell University Press, 1997), 29.
} 
Marine Board, claims that Jim Crow Point, located approximately ten miles west of Cathlamet on the north side of the Columbia, was named for Saules. If this is true, Saules may have lived there toward the end of his life. "Jim Crow" is a reference to the 1830s minstrel song "Jump Jim Crow," which was one of the most well known songs of the mid-nineteenth century. By the late 1830 s, "Jim Crow" had become a pejorative term applied to black people. ${ }^{386}$

There is no definitive information on Saules's death, but he apparently died sometime in the 1850s. Charles Melville Scammon's 1875 profile of Saules for the Overland Monthly, suggests that he drowned somewhere on the Columbia River between the mouth of the Willamette River and Astoria and was buried near the shore of Cathlamet Bay. ${ }^{387}$ Silas B. Smith believed that Saules died sometime after 1848, although he did not know the cause or location. ${ }^{388}$ Historian Elizabeth McLagan speculated that Saules died in a boat accident in December of 1851 . Her evidence is an article in the December 30, 1851 edition of the Oregon Spectator:

We learn that three negro men have been engaged for some time past in selling liquor to Indians, a short distance from Milton, Washington county, and that the citizens of that place were so much annoyed by their continued drunkenness and debauchery, that several of the citizens started in a boat to take the negroes into custody. This they succeeded in doing, and when taking them before the Magistrate, by some means the boat was capsized, and one of the negroes drowned. For want of sufficient evidence to commit them, the other two were discharged. Upon the examination it was stated by these negroes that they were in the employ of a resident of [Oregon City], and that the liquor they were engaged in selling was his property. ${ }^{389}$

\footnotetext{
${ }^{386}$ Comer Vann Woodward, The Strange Career of Jim Crow (Oxford University Press, 1955), 7.

387 Scammon, "Pioneer Nig Saul," 275-276.

${ }^{388}$ Smith, "Celebrations in Clatsop County," 40.

389 "Drowned," Oregon Spectator, December 30, 1851, 2.
} 
It is certainly possible that the drowned man was Saules, although it is somewhat surprising that the article did not state his name given his local notoriety. But the location of the event does suggest Saules' involvement. While the town of Milton no longer exists, it was located on the Columbia River near the town of St. Helens, Oregon, less than fifty miles upriver from Cathlamet. It is also noteworthy that settlers accused the three black men of selling liquor to Natives, an illegal activity in Oregon Territory. Saules had a long-standing relationship with local Native communities and, given the economic opportunities available to black men living Oregon in the 1850s, selling liquor was probably one of the few viable means of employment available to him.

The lack of any specific mention of Saules's death in the local media or government records is indicative of how marginalized he and the other non-white residents of Oregon had become by the early $1850 \mathrm{~s}$. His absence from the 1850 U.S. Census further reinforces this impression. Many of the American settlers who began arriving in the early 1840 s blamed many of the nation's problems on non-whites and hoped to establish an ethnically homogeneous community in Oregon. After some furtive steps in this direction, settlers soon realized how problematic and contentious racial exclusion could be. Yet through the 1848 Territorial Act, the 1849 black exclusion law, and the 1850 Donation Land Act, the territorial legislature and federal government further enshrined white supremacy in Oregon. Furthermore, the threat of efficient state violence supported such laws, in the form of more organized forms of law enforcement and the U.S. armed forces. Finally, the initial trickle of westward expansion became a torrential storm in the 1850s, and Oregon's white population increased from 
approximately 1,000 in 1844 to 52,465 by $1860 .{ }^{390}$ As the nation became embroiled in sectional tensions that eventually erupted in the Civil War, Oregonians continued to reaffirm the principle of racial exclusion. However, blacks, Natives, Chinese, Pacific Islanders continued to live in the region despite the presence of laws and, like Saules, employed creative means to navigate and resist the forces of white supremacy.

${ }^{390}$ McLagan and Project, A Peculiar Paradise, 185. 


\section{Conclusion}

The last specific mention of Saules in the historical record places him in Astoria on July 4, 1849. In 1869, Charles Melville Scammon penned an article for the Overland Monthly entitled "In and around Astoria." In it, Scammon quotes an attendee of the 1849 Fourth of July celebration who remarked: “Old nigger Saul, one of the Peacock's crew, was the fiddler. When we began to dance, the floor was a little wavy; but it was all on a level afore morning, though!"391 While Scammon was never one to avoid poetic license, this is a fitting final image of Saules: performing for white American settlers celebrating the anniversary of their nation's founding. And as Scammon's interlocutor implies, this was a spirited affair since it was the first Fourth of July since Oregon became a U.S. Territory the previous August. The location was also appropriate, as it was held in the Shark House, built three years earlier as winter quarters for officers and crew of the U.S.S. Shark after their ship--once briefly helmed by Saules himself-was wrecked at the Columbia bar.

Yet one wonders what Saules thought about this affair, or how he felt about the nation of his birth. The U.S. Constitution, which contained scant legal protections for free black people living in the United States, also allowed individual states and territories to disenfranchise or exclude them. And if Saules had been a runaway slave, the Constitution also contained a fugitive slave clause that required the return of escaped slaves. The arrival of American settlers had provided some employment opportunities for him, both as riverman and musician. But these immigrants also sought to transform the previously

\footnotetext{
${ }^{391}$ Charles Melville Scammon, "In and Around Astoria," Overland Monthly and Out West Magazine., $1869,497$.
} 
multiethnic region into a white man's country. As a black man attempting to navigate a social hierarchy increasingly predicated on race, Saules attracted attention, much of it unwanted. This resulted in legal troubles, dislocation, and harrowing physical punishment. His presence and activities also inspired, either directly or indirectly, several racist laws in the region. And around the same time Saules was performing at the Shark House, Oregon politicians were busy conceiving two of these: the 1849 black exclusion law and the 1850 Donation Land Act.

Despite many Oregonians' antipathy toward blacks, only one man, Jacob Vanderpool, was ever convicted and removed under the 1849 exclusion law, which was inadvertently repealed in 1853. Vanderpool was from the West Indies and, like Saules, was a black sailor who had traveled widely. ${ }^{392}$ While Vanderpool came to Oregon to become a businessman, his former occupation is a reminder that the law was specifically intended to regulate the behavior of black seamen. In 1850, Vanderpool, who was denied a generous donation land claim due to his race, opened a saloon and boarding house in Oregon City. In 1851, his growing business interests apparently attracted the attention of Theophilus Magruder, former land claim recorder for the provisional government and proprietor of the Main Street House, an Oregon City hotel that probably competed with Vanderpool's establishment. Magruder had Vanderpool arrested and jailed for violating the 1849 exclusion law. On August 25, 1851, Vanderpool was convicted and sentenced to leave the territory within thirty days. In a brief article on the case, the Oregon Spectator applauded the court's decision and mentioned Saules's old friend Winslow Anderson as a

\footnotetext{
${ }^{392}$ According to court documents, Vanderpool had been in Philadelphia and China prior to arriving in Oregon. See "Theophilus Magruder v. Jacob Vanderpool Case Documents," August 1851, Leaf 7, B 122, Special Collections and University Archives, University of Oregon Libraries.
} 
deserving candidate for exclusion: "A notorious villain, who calls himself Winslow, has cursed this community with his presence for a number of years. All manner of crimes have been laid to his charge — we shall rejoice at his removal." ${ }^{393}$ However the article fails to mention that Anderson, like Saules, was exempt from the law since he already resided in the territory when the law was passed.

While generous land claims lured thousands of white Americans to Oregon in the $1850 \mathrm{~s}$, the racialist attitudes of these new Oregonians were very similar to those of their predecessors. Anti-black rhetoric during this period, which contained references to both black sailors and black-Native collaboration, also suggested the legacy of Saules. In 1857, as Oregon headed toward statehood, white male voters in the territory approved adding a black exclusion clause to the state constitution by a margin of 8,640 to $1,081 .^{394}$ This clause banned any further immigration of black people once the U.S. government approved statehood and also compounded the exclusionary aspects of the Donation Land Law by forbidding blacks from owning real estate. ${ }^{395}$

Only one delegate to the constitutional convention, William Watkins, a New Yorker by birth, spoke out in opposition of this clause. According to Watkins, "[T]he free negro has claims upon us which we can neither ignore nor destroy; he was born upon our soil, he speaks our language, he has been taught our religion, and his destiny and ours are eternally linked." ${ }^{396}$ Yet Watkins was no abolitionist. His primary reasons for objecting to the law were commercial. Watkins believed that Oregon's future was in overseas

\footnotetext{
393 Oregon Spectator, September 2, 1851.

${ }^{394}$ Nokes, Breaking Chains, 142.

395 Ibid.

${ }^{396}$ Oregon Constitutional Convention, and Oregon Historical Society, The Oregon Constitution and Proceedings and Debates of the Constitutional Convention of 1857 (State Printing Dept., 1926), 385.
} 
commerce rather than agriculture. He contended that the benefits of maritime commerce outweighed the risk that black sailors like Saules would come to the region and remain there permanently. And because so many free blacks served aboard vessels, Watkins reasoned that the clause would discourage captains from bringing their ships to Oregon's ports since they would have no means to protect their black crewmembers. ${ }^{397}$ Sympathetic to the plight of black sailors, he offered this hypothetical situation:

Suppose, sir, as we are a commercial people, that some negro, unlearned and unlettered in your constitutional provision, who honestly earns his living by serving as cook or waiter on one of your many vessels, lands at the emporium of commerce. His property may be taken, his life endangered, his limbs broken by some fiend in human shape; but your laws, framed to protect the weak, the innocent, the helpless, and to administer justice, could give him no redress. ${ }^{398}$

However, Watkins was hardly free of racist vitriol, as at the same time he defended the rights of black sailors, he argued forcibly in favor of excluding Chinese people from living in Oregon. ${ }^{399}$

In 1857 , Oregon voters also voted to ban slavery by a large margin, although many territorial residents were ambivalent regarding the actual rights of enslaved people living in the territory. Most opponents to slavery in Oregon were more concerned with the potential economic effects of slavery rather than its human costs. For instance, in his “Free State Letter," Oregon Judge George H. Williams invoked "free soil” ideology to attack the notion of bringing slavery to Oregon, claiming the institution would impair the ability of white workingmen to compete in a free labor system. He also dredged up old fears of black slaves joining forces with local Native groups, reminding his readers of

\footnotetext{
${ }^{397}$ Ibid.

${ }^{398}$ Ibid.

${ }^{399}$ Nokes, Breaking Chains, 137.
} 
how, during the Second Seminole War, forty fugitive slaves combined with Seminoles to kill 108 U.S. soldiers. ${ }^{400}$ Perhaps more importantly, Williams offered no condemnation of southern slavery and instead argued that Oregon's climate was unsuitable for the production of cotton, rice and sugar. ${ }^{401}$ Furthermore, Oregonians often ignored or tolerated the small but significant number of enslaved blacks brought to the region via the Oregon Trail in the 1840s and 1850s. For instance, Robin Holmes, a former slave, fought a protracted legal battle to free his two children from their owner, Oregon politician Nathaniel Ford. ${ }^{402}$ While in 1853 Holmes was ultimately successful, his difficulty in freeing his children suggest that in antebellum Oregon, residents respected the property rights of slave owners more than the rights of black people to their own liberty.

One purpose of placing Saules at the center of this narrative was to explore why he, and others like him, constituted such a threat during the early Americanization of Oregon. But another key reason is to demonstrate the centrality of racial exclusion to the creation and maintenance of private property and segregated social spaces in Oregon, as well as how settler colonialism affected those pushed to the margins of settler society. In the nineteenth century, the protection of property rights, in particular land rights, was crucial to Jeffersonian (and Jacksonian) democracy, market capitalism, and the settler colonial project itself. Of course, during the Enlightenment in Europe, the notion that an individual could own property was considered radical and democratizing, particularly in an era in which most land was owned either by royalty, noblemen, or the Church. Yet the

\footnotetext{
${ }^{400}$ George H. Williams, "The 'Free-State Letter' of Judge George H. Williams. Slavery in Oregon," The Quarterly of the Oregon Historical Society 9, no. 3 (September 1, 1908): 263.

${ }^{401}$ Ibid., 266.

${ }^{402}$ In 2013, historian Gregory Nokes published the definitive account of slavery in Oregon and Holmes v. Ford. See Nokes, Breaking Chains.
} 
American settlers in Oregon crafted a system by which they could legally expropriate land and displace whomever was previously using or living on it. They eventually had that system enshrined and enforced by the U.S. government. This thesis contains several examples of such displacement, most involving members of the previous multiethnic social order, such as Native people, Methodist missionaries, HBC employees, and Saules himself. However, those members of the middle ground racialized as white could rejoin settler society as long as they accepted American hegemony. This was never a possibility for Saules or other non-white people living in the region. American settlers used legal means to draw a color line that helped dismantle any last remnants of the middle ground and ensured that Oregon's white citizens would control the distribution of land and, by extension, the distribution of wealth and power.

The land-centered, race-based settler colonialist project was remarkably successful in the Pacific Northwest, and Oregon remained essentially a white man's country for several generations. While the end of the Civil War and the ratification of the thirteenth, fourteenth, and fifteenth amendments to the U.S. Constitution established the illegality of both slavery and black exclusion, Oregon remained a place where many black people did not feel welcome. As a potent symbol of this fact, Oregon did not officially ratify the fifteenth amendment, which granted voting rights to adult black males, until 1959. In addition, from 1855 to 1877 , much of region's Native population was engaged in a brutal series of Indian Wars that resulted in a mass transfer of Native people to reservations. Other racial groups, such as Chinese, Japanese, and Mexicans, have also faced exclusion and dislocation in Oregon. And despite the fact that many 
Oregonians reject the notion that race is a biological determinant of behavior, Oregon remains one of the whitest states in an American West increasingly defined by racial diversity. But people of various ethnic backgrounds have continued to come and live in Oregon despite these challenges. They have come for many different reasons and, like Saules, have often had to find creative ways to navigate and resist racial prejudice in the region. They have also been a part of a crucial process of mutual cultural transmission that has continually challenged Oregon's reputation for racial homogeneity, suggesting that Oregon's middle ground never went away in its entirety. 


\section{Bibliography}

\section{Primary Sources and Government Documents}

“Alexander Lattie's Fort George Journal, 1846." Oregon Historical Quarterly 64, no. 3 (September 1, 1963): 197-245.

“An Address Delivered By Daniel Webster." Granite Monthly: A New Hampshire Magazine, 1882.

Blanchet, Francis Norbert. Historical Sketches of the Catholic Church in Oregon, During the Past Forty Years, 1878.

Burnett, Peter Hardeman. Recollections and Opinions of an Old Pioneer. D. Appleton, 1880.

Clarke, Samuel Asahel. Pioneer Days of Oregon History. J.K. Gill Company, 1905.

“Documents,” Oregon Historical Quarterly, 4, no. 4 (December 1903): 394-409.

Erskine, Charles. Twenty Years Before the Mast: With the More Thrilling Scenes and Incidents While Circumnavigating the Globe Under the Command of the Late Admiral Charles Wilkes, 1838-1842. Lakeside/Donnelley, 2006.

Gray, William Henry. A History of Oregon, 1792-1849 Drawn From Personal Observation and Authentic Information. Library of Alexandria, 1870.

H, Daniel \& Frost Lee, Joseph, Daniel Lee, and Joseph H. Frost. 10 Years in Oregon. Glen Adams, 1968.

Howison, Neil M. "Report of Lieutenant Neil M. Howison on Oregon, 1846: A Reprint." The Quarterly of the Oregon Historical Society 14, no. 1 (March 1, 1913): 1-60.

Jefferson, Thomas. Notes on the State of Virginia. J.W. Randolph, 1853.

Lester, William Wharton. Decisions of the Interior Department in Public Land Cases, And Land Laws Passed by the Congress of the United States; Together with the Regulations of the General Land Office. H. P. \& R. H. Small, 1860.

McKean, Samuel T. "Memoirs of Samuel T. McKean.” Cumtux: Clatsop County Historical Society Quarterly 13, no. 1 (Winter 1992): 2-11.

Meany, Edmond S. "Diary of Wilkes in the Northwest." The Washington Historical 
Quarterly 16, no. 1 (January 1, 1925): 49-61.

Nesmith, James W. "Diary of the Emigration of 1843." The Quarterly of the Oregon Historical Society 7, no. 4 (December 1, 1906): 329-59.

O’Sullivan, John. “Annexation.” United States Magazine and Democratic Review 17, no. 1 (August 1845): 5-10.

The Oregon Constitution and Proceedings and Debates of the Constitutional Convention of 1857. State Printing Dept., 1926.

Pickett, Charles Edward. Address To The Veterans Of The Mexican War: Embodying A Historical Contrast Of The Two Great Political Parties Of The United States On Vital Issues. Kessinger Publishing, 2007.

Portrait and Biographical Record of the Willamette Valley, Oregon: Containing Original Sketches of Many Well Known Citizens of the Past and Present. Chapman Publishing Company, 1903.

Reynolds, William. The Private Journal of William Reynolds: United States Exploring Expedition, 1838-1842. Penguin, 2004.

Schafer, Joseph. "Documents Relative to Warre and Vavasour's Military Reconnaissance in Oregon, 1845-6." The Quarterly of the Oregon Historical Society 10, no. 1 (March 1, 1909): 1-99.

Simpson, George, Peter Skeen Ogden, Henry I. Warre, and M. Vavasour. "Secret Mission of Warre and Vavasour." The Washington Historical Quarterly 3, no. 2 (April 1, 1912): 131-53.

Smith, Silas H. "Celebrations in Clatsop County." Cumtux: Clatsop County Historical Society Quarterly 24, no. 1 (Winter 2004): 37-42.

Statutes of a General Nature Passed by the Legislative Assembly of the Territory of Oregon: At the Second Session, Begun and Held at Oregon City, December 2, 1850. In the Seventy-Fifth Year of the Independence of the United States. Asahel Bush, Territorial Printer, 1851.

U.S. Congress. Congressional Globe. $29^{\text {th }}$ Cong., $1^{\text {st }}$ Sess., 1846.

U.S. Congress. House. Index to the Reports of Committees of the House of Representatives for the First and Second of the Forty-Fifth Congress 1877-1878. $45^{\text {th }}$ Cong., 2d Sess., 1878. 
U.S. Congress. Senate, Report of the Commissioner of Indian Affairs, $28^{\text {th }}$ Cong., $2 \mathrm{~d}$ Sess., 1844. Vol. 1, S.Doc. 1, serial 449.

U.S. Congress. United States Office of Indian Affairs. Annual Report of the Commissioner of Indian Affairs. $29^{\text {th }}$ Cong. $1^{\text {st }}$ Sess., 1846.

White, Elijah. Ten Years in Oregon: Travels and Adventures of Dr. E. White and Lady, West of the Rocky Mountains; with Incidents of Two Sea Voyages via Sandwich Islands around Cape Horn, Containing, Also, a Brief History of the Missions and Settlement of the Country ... Description of the Soil, Production and Climate. Press of Andrus, Guantlett, \& Co., 1850.

Wilkes, Charles. Narrative of the United States Exploring Expedition: During the Years 1838, 1839, 1840, 1841, 1842. In 5 Vol., with 13 Maps, 1850.

- "Report on the Territory of Oregon." The Quarterly of the Oregon Historical Society 12, no. 3 (September 1, 1911): 269-99.

Williams, George H. "The 'Free-State Letter' of Judge George H. Williams. Slavery in Oregon." The Quarterly of the Oregon Historical Society 9, no. 3 (September 1, 1908): 254-73.

\section{Articles and Anthology Book Chapters}

Barry, J. Neilson. "Astorians Who Became Permanent Settlers." The Washington Historical Quarterly 24, no. 3 (July 1, 1933): 221-31.

Bordwell, Constance. "Delay and Wreck of the Peacock: An Episode in the Wilkes Expedition." Oregon Historical Quarterly 92, no. 2 (July 1, 1991): 119-98.

Burnett, D. Graham. "Hydrographic Discipline among the Navigators: Charting an 'Empire of Commerce and Science' in the Nineteenth-Century Pacific." In The Imperial Map: Cartography and the Mastery of Empire, edited by James R. Akerman, 185-260. University of Chicago Press, 2009.

Clayton, D. "The Creation of Imperial Space in the Pacific Northwest." Journal of Historical Geography 26, no. 3 (July 1, 2000): 327-50.

Colbert, Mildred. "Naming and Early Settlement of Ilwaco, Washington." Oregon Historical Quarterly 47, no. 2 (June 1, 1946): 181-95.

Covington, James W. "The Armed Occupation Act of 1842." The Florida Historical Quarterly 40, no. 1 (July 1, 1961): 41-52. 
Elliott, T. C. "Peter Skene Ogden, Fur Trader." The Quarterly of the Oregon Historical Society 11, no. 3 (September 1, 1910): 229-78.

Gough, Barry M. "The Royal Navy and Oregon Crisis, 1844-1846." BC Studies: The British Columbian Quarterly 0, no. 9 (1971): 15-937.

Loewenberg, Robert J. "Creating a Provisional Government in Oregon: A Revision." The Pacific Northwest Quarterly 68, no. 1 (January 1, 1977): 13-24.

Mcclintock, Thomas C. "James Saules, Peter Burnett, and the Oregon Black Exclusion Law of June 1844." The Pacific Northwest Quarterly 86, no. 3 (July 1, 1995): $121-30$.

Scammon, Charles Melville. "In and Around Astoria." Overland Monthly and Out West 3, no. 6 (December 1, 1869): 495-499.

_. "Pioneer Nig Saul." In The Overland Monthly, edited by Bret Harte, 273-76. A. Roman \& Company, 1875.

Schafer, Joseph. “Jesse Applegate: Pioneer, Statesman and Philosopher." Washington Historical Quarterly 1, no. 4 (January 4, 2010): 217-33.

Shine, Gregory Paynter. "“A Gallant Little Schooner': The U.S. Schooner Shark and the Oregon Country, 1846." Oregon Historical Quarterly 109, no. 4 (December 1, 2008): 536-65.

Sylvester, Avery. "Voyages of the Pallas and Chenamus, 1843-45 (In Two Parts, Part II).” Oregon Historical Quarterly 34, no. 4 (December 1, 1933): 359-71.

Taylor, Quintard. "Slaves and Free Men: Blacks in the Oregon Country, 1840-1860." Oregon Historical Quarterly 83, no. 2 (July 1, 1982): 153-70.

Veracini, Lorenzo. "Introducing.” Settler Colonial Studies 1, no. 1 (2011): 1-12.

—. Settler Colonialism: A Theoretical Overview. Palgrave Macmillan, 2010.

_. "The Settler-Colonial Situation.” Native Studies Review 19, no. 1 (July 2010): 101-18.

Wolfe, Patrick. "Race and Racialisation: Some Thoughts." Postcolonial Studies 5, no. 1 (2002): 51-62.

- "Settler Colonialism and the Elimination of the Native." Journal of Genocide Research 8, no. 4 (2006): 387-409. 


\section{Books and Unpublished Manuscripts}

Akerman, James R. The Imperial Map: Cartography and the Mastery of Empire. University of Chicago Press, 2009.

Alexander, Michelle. The New Jim Crow: Mass Incarceration in the Age of Colorblindness. The New Press, 2010.

Anderson, Benedict. Imagined Communities: Reflections on the Origin and Spread of Nationalism. Verso, 2006.

Applegate, Shannon. Talking on Paper: An Anthology of Oregon Letters and Diaries. Oregon State University Press, 1994.

Bancroft, Hubert Howe, and Frances Fuller Victor. History of Oregon, Volume One. The History Company, 1886.

—. History of Oregon, Volume Two. The History Company, 1888.

Bartlett, Ichabod Sargent. History of Wyoming. S. J. Clarke Publishing Company, 1918.

Belich, James. Replenishing the Earth: The Settler Revolution and the Rise of the Anglo World. Oxford University Press, 2011.

Berwanger, Eugene H. The Frontier against Slavery: Western Anti-Negro Prejudice and the Slavery Extension Controversy. University of Illinois Press, 2002.

Billington, Ray Allen, and Martin Ridge. Westward Expansion: A History of the American Frontier. UNM Press, 2001.

Bolster, W. Jeffrey. Black Jacks: African American Seamen in the Age of Sail. Cambridge, Mass.: Harvard University Press, 1997.

Boyd, Robert T. Chinookan Peoples of the Lower Columbia, 2013.

Brosnan, Cornelius J. Jason Lee, Prophet of the New Oregon. Rutland, VT: Academy Books, 1985.

Brownell, Jean. Negroes in Oregon Before the Civil War. Oregon Historical Society. Unpublished Manuscript, 1962.

Chaffin, Tom. Pathfinder: John Charles Frémont and the Course of American Empire. Macmillan, 2004. 
Dark, Russell. Bar Sinister: The Story of the Columbia River Bar Pilots. Clatsop County Historical Society: Unpublished Manuscript, n.d.

Dodds, Gordon B. Oregon: A History. W. W. Norton \& Company, 1977.

Douthit, Nathan. Uncertain Encounters: Indians and Whites at Peace and War in Southern Oregon, 1820s-1860s. Corvallis: Oregon State University Press, 2002.

Faragher, John Mack. Women and Men on the Overland Trail. New Haven: Yale University Press, 2001.

Galbraith, John S. The Hudson's Bay Company as an Imperial Factor, 1821-1869. University of California Press, 1957.

Gates, Paul W, Robert W Swenson, United States, and Public Land Law Review Commission. History of Public Land Law Development. Wm. W. Gaunt \& Sons, 1987.

Gilroy, Paul. The Black Atlantic: Modernity and Double Consciousness. Harvard University Press, 1993.

Guillaumin, Colette. Racism, Sexism, Power and Ideology. Routledge, 2002.

Horsman, Reginald. Race and Manifest Destiny: The Origins of American Racial AngloSaxonism. Harvard University Press, 1981.

Hunt, Herbert, and Floyd C. Kaylor. Washington, West of the Cascades: Historical and Descriptive; the Explorers, the Indians, the Pioneers, the Modern. S. J. Clarke Publishing Company, 1917.

Jacobs, Margaret D. White Mother to a Dark Race: Settler Colonialism, Maternalism, and the Removal of Indigenous Children in the American West and Australia, 1880-1940. University of Nebraska Press, 2011.

Jeynes, William. American Educational History School, Society, and the Common Good. Thousand Oaks: SAGE Publications, 2007.

Johnson, David Alan. Founding the Far West: California, Oregon, and Nevada, 18401890. University of California Press, 1992.

Joyner, Charles W. Shared Traditions: Southern History and Folk Culture. University of Illinois Press, 1999. 
Linebaugh, Peter, and Marcus Rediker. The Many-Headed Hydra: Sailors, Slaves, Commoners, and the Hidden History of the Revolutionary Atlantic. Boston: Beacon Press, 2000.

McLagan, Elizabeth, and Oregon Black History Project. A Peculiar Paradise: A History of Blacks in Oregon, 1778-1940. Georgian Press, 1980.

Melville, Herman. Moby Dick. Bantam Books, 1981.

Morrison, Dorothy Nafus. Outpost: John McLoughlin \& the Far Northwest. Portland: Oregon Historical Society Press, 1999.

Morrissey, Katherine G. Mental Territories: Mapping the Inland Empire. First Edition. Cornell University Press, 1997.

Nokes, R. Gregory. Breaking Chains: Slavery on Trial in the Oregon Territory. Corvallis, OR: Oregon State University Press, 2013.

Omi, Michael, and Howard Winant. Racial Formation in the United States: From the 1960s to the 1990s. Psychology Press, 1994.

Philbrick, Nathaniel. Sea of Glory: America's Voyage of Discovery : The U.S. Exploring Expedition, 1838-1842. Penguin, 2004.

Pomeroy, Earl Spencer. The Pacific Slope: A History of California, Oregon, Washington, Idaho, Utah, and Nevada. University of Nevada Press, 1965.

Powell, Lawrence Clark. Philosopher Pickett: The Life and Writings of Charles Edward Pickett, Esq., of Virginia. University of California Press, 1942.

Prince, Hugh. Wetlands of the American Midwest: A Historical Geography of Changing Attitudes. University of Chicago Press, 2008.

Robbins, William G. Landscapes of Promise: The Oregon Story, 1800-1940. University of Washington Press, 1999.

—. Oregon: This Storied Land. Oregon Historical Society Press, 2005.

Ruby, Robert H., and John A. Brown. Indians of the Pacific Northwest: A History. University of Oklahoma Press, 1988.

Schwantes, Carlos Arnaldo. The Pacific Northwest: An Interpretive History. Revised. University of Nebraska Press, 2000. 
Stanton, William Ragan. The Great United States Exploring Expedition of 1838-1842. Berkeley: University of California Press, 1975.

Strong, Thomas Nelson. Cathlamet on the Columbia: Recollections of the Indian People and Short Stories of Early Pioneer Days in the Valley of the Lower Columbia River. The Holly Press, 1906.

Taylor, Quintard. In Search of the Racial Frontier: African Americans in the American West, 1528-1990. W. W. Norton \& Company, 1999.

The Oregon Grower. Oregon Growers Co-operative Association, 1921.

Tomblin, Barbara. Bluejackets and Contrabands: African Americans and the Union Navy. University Press of Kentucky, 2009.

Viola, Herman Joseph, and Carolyn Margolis. Magnificent Voyagers: The U.S. Exploring Expedition, 1838-1842. Smithsonian, 1985.

Watson, Bruce McIntyre. "Lives Lived West of the Divide: A Biographical Dictionary of Fur Traders Working West of the Rockies, 1793-1858." Accessed September 29, 2013. http://www.lulu.com/shop/bruce-mcintyre-watson/lives-lived-west-of-thedivide-a-biographical-dictionary-of-fur-traders-working-west-of-the-rockies1793-1858/ebook/product20951764.html;jsessionid=A6B2B4ABA128846DBE5D81F1E3BBD496.

Whaley, Gray H. Oregon and the Collapse of Illahee: U.S. Empire and the Transformation of an Indigenous World, 1792-1859. University of North Carolina Press, 2010.

White, Richard. The Middle Ground: Indians, Empires, and Republics in the Great Lakes Region, 1650 - 1815. Cambridge University Press, 2011.

- The Roots of Dependency: Subsistence, Environment, and Social Change Among the Choctaws, Pawnees, and Navajos. University of Nebraska Press, 1988.

Wolf, Eva Sheppard. Race and Liberty in the New Nation: Emancipation in Virginia from the Revolution to Nat Turner's Rebellion. Louisiana State University Press, 2006.

Wolfe, Patrick. Settler Colonialism. Continuum, 1998.

Woodward, Comer Vann. The Strange Career of Jim Crow. Oxford University Press, 1955.

Wright, E. W. Lewis \& Dryden's Marine History of the Pacific Northwest: An Illustrated 
Review of the Growth and Development of the Maritime Industry, from the Advent of the Earliest Navigators to the Present Time, with Sketches and Portraits of a Number of Well Known Marine Men. Lewis \& Dryden Printing Company, 1895.

\section{Newspapers}

The Seattle Times

Oregon Spectator

Daily Astorian

\section{Archive}

Eugene, Oregon. University of Oregon Libraries. Special Collections and University Archives, Theophilus Magruder v. Jacob Vanderpool Case Documents, August 1851.

\section{Website}

"Center for the Study of the Pacific Northwest." Accessed February 17, 2014.

https://www.washington.edu/uwired/outreach/cspn/Website/Classroom\%20Materi als/Pacific\%20Northwest\%20History/Lessons/Lesson\%209/Census\%20Data.html 